$$
\operatorname{DOE} / C E / 21005-T_{1}
$$

$\mathrm{DOE} / \mathrm{CE} / 21005--\mathrm{Tl}$

DE92 006576

\title{
Passive Solar Design Strategies: \\ Remodeling Guidelines for Conserving Energy at Home
}

\section{Baltimore, MD}

Passive Solar Industries Council

National Renewable Energy Laboratory

Charles Eley Associates

- Environmental Research Groups International, Inc.

\section{MACTRR}


This document was prepared under the sponsorship of the National Renewable Energy Laboratory and produced with funds made avallable by the United States Department of Energy. Nelther the United States Department of Energy, the Nattonal Renewable Energy Laboratory, the Passive Solar Industrles Council nor any of tts member organizations, nor any of their employees, nor any of their contractors, subcontractors, or their employees, makes any warranty, expressed or implied, or assumes any legal llability or responsibility for the accuracy, completeness or usefulness of any information, apparatus, product or process disclosed, or represents that its use would not infringe privately owned rights. The views and opinions do not necessarily state or reflect those of the United States government, the National Renewable Energy Laboratory, or any agency thereof. This document was preparet with the assistance and participation of representattves from many organizations. but the vews and opinions expressed represent general consensus and avallable information. Unanimous approval by all organizations is not implied. 


\section{Guidelines}

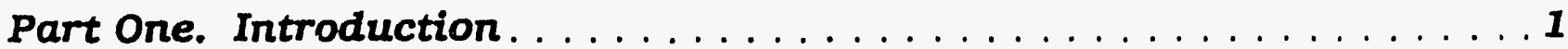

1. Introduction to the Passtve Solar Design Strategies Package . . . . . . . . . . . . . 2

2. Passive Solar Remodeling . . . . . . . . . . . . . . . . . . . . 2

3. Passive Solar Performance Potential . . . . . . . . . . . . . . . . . . . 6

4. Establishing the Energy Performance of the Existing Structure . . . . . . . . . .

Part Two. Basics of Passive Solar . . . . . . . . . . . . . . . . 9

1. Why Passtve Solar? More than a Question of Energy . . . . . . . . . . . . . . . 10

2. Key Concepts: Energy Conservation, Suntempertng, Passtve Solar . . . . . . . . . 11

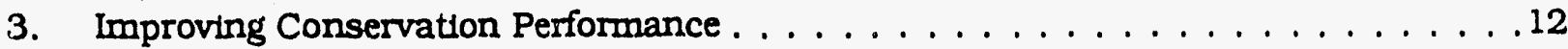

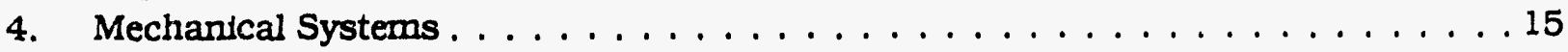

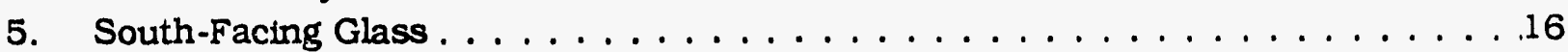

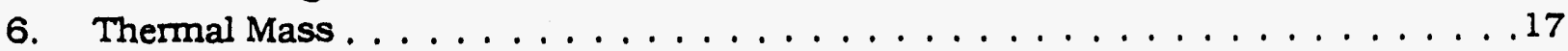

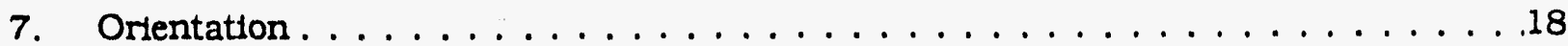

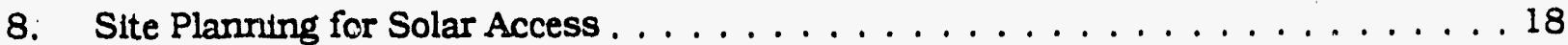

9. Interior Space Planning . . . . . . . . . . . . . . . . . . 19

10. Putting it Together: The House as a System . . . . . . . . . . . . . . . . 20

\section{Part Three. Strategies for Improving Energy Performance}

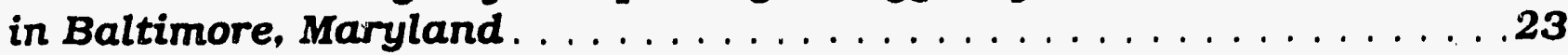

1. The Example Tables . . . . . . . . . . . . . . . . . . . . . 24

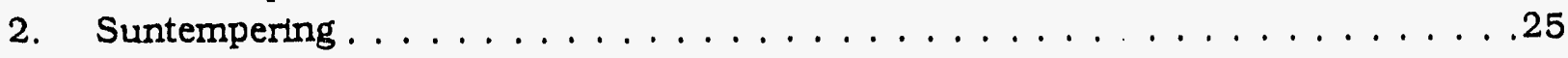

3. Direct Gain . . . . . . . . . . . . . . . . . . . . 26

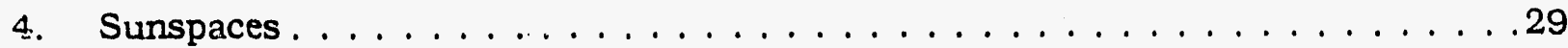

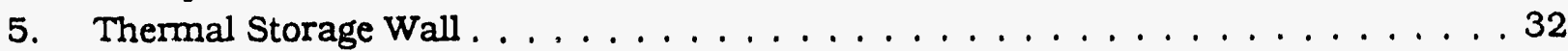

6. Combined Systems . . . . . . . . . . . . . . . . . . . . . . 34

7. Natural Cooling Gurdelines . . . . . . . . . . . . . . . . . . . 34

\section{Worksheets}

Blank Worksheets, Data Tables, and Worksheet Instructions

\section{Worked Example}

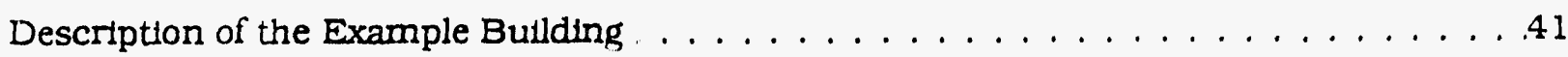

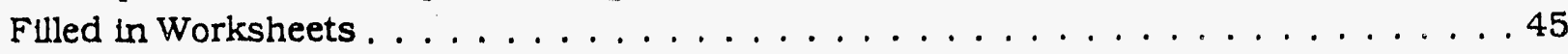

Annotated Worksheet Tables . . . . . . . . . . . . . . . . . 50

\section{Appendix}

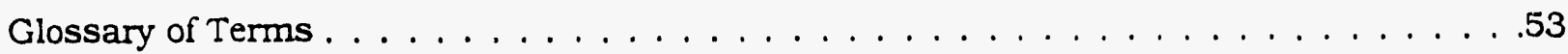

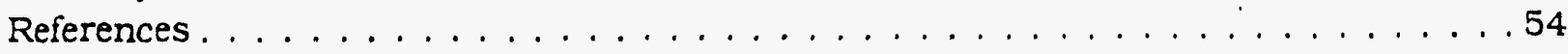

Summary Tables . . . . . . . . . . . . . . . . . . . . . 56

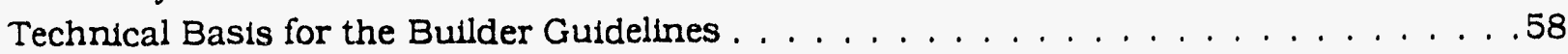




\section{Acknowledgements}

\section{Passive Solar Design \\ Strategles: Remodeling \\ Guidelines for Conserving}

Energy at Home is an effort by a unique group of organizations and individuals. The challange of creating an effective design tool that could be customized for the specific needs of remodelers in cities and towns all over the U.S. called for talents and experience of speciallsts in many different areas of expertise.

\section{Passive Solar Design}

Strategies is based on research sponsored by the United States Department of Energy (DOE) Solar Bulldings Program, and carried out primarlly by the Los Alamos National Laboratory (LANL), the National Renewable Energy Laboratory (NREL) and the Florida Solar Energy Center (FSEC).

The National Association of Home Builders (NAHB) Remodeler's Council have provided invaluable advice and assistance during the development of the Guidelines.

This information is based on

\section{Passive Solar Design}

\section{Sirategles: Guidelines for}

Home Builders. PSIC expresses particular gratitude to the following individuals: $J$. Douglas Balcomb, NREL and LANL, whose work is the basis of the Guidelines; Norm Weaver, Environmental Research Groups International, Inc., members of the NAHB Remodeler's Council, especially Bryan Patchan and

Dickson Clements, for the benefits of their long-term experience in bullding energy efficient retrofits; at US DOE. John Mullhone, Deputy Assistant Secretary for Bullding Technologies, Mary-Margaret Jenior, Program Manager of the Offlce of Solar Heat

Technologies, Nancy Carlisle at NREL. Helen English.

Executive Director of PSIC and Sharl Kaminsky, Project Manager of the Remodeling Guidelines. David Johnston, Lightworks Construction, Inc. and the National Association of the Remodeling Industry, who worked on the Guidelines from its early stages and was instrumental in the success of the first pllot workshop in Washington. D.C.

Although all the members of PSIC, especially the Remodelers Task Group, contributed the financial and technical support of the Guidelines, several contributed way beyond the call of duty. Stephen Szoke. National Concrete Masonry Assoctation. Chalrman of PSIC's Board of Directors; Bion

Howard, The Alliance to Save Energy, and Mark Kelley. Bullding Science Engineering all gave unstintingly of their time, their expertise, and their enthusiasm. 


\section{Part One: Introduction}

1. Introduction to the Passive Solar Design Strategies Package

2. Passive Solar Remodeling

3. Passive Solar Performance Potential

4. Establishing the Energy Performance of the Existing Structure 


\section{Introduction to the Passive Solar Design Strategies Package}

The idea of passive solar is simple, but applying it effectively does require information and attention to the details of design and construction. Some passive solar techniques are modest and low-cost, and require only small changes in a remodeler's typical practice. At the other end of the spectrum, some passive solar systems can almost eliminate a house's need for purchased heating (and in some cases, cooling) energy - but probably at a relatively high first cost.

In between are a broad range of energy-conserving passive solar techniques. Whether $\mathrm{O}_{i}$ not they are cost-effective. practical and attractive enough to offer a market advantage to any individual remodeler depends on very specific factors such as local costs, climate, and market characteristics.

Passive Solar Design Strategies: Remodeling Guidelines for Conserving Energy at Homes is written to help give remodelers the information they need to make these decisions.

Passive Solar Design Strategies is a package in three basic parts:

\section{- The Guidelines contain} information about passive solar techniques and how they work. and piovides specific examples of systems whych will save various percentages of energy;
The Worksheets offer a simple, fll-in-the-blank method to pre-evaluate the performance of a specific design.

\section{- The Worked Example} demonstrates how to complete the worksheets for a typical residence.

\section{Passive Solar Remodeling -- the connection to the remodeling market}

A passive solar remodel implies that the proposed remodeling project incorporates elements which collect, store, and distribute solar energy by natural means related to home heating and coolling. The collected solar energy reduces the use of the conventional fuels such as gas, oll, and electricity.

The decision to remodel a house is usually made because the options of buying a new house or a different house are not desirable. Remodeling a home becomes the perfect solution to accommodate new living patterns or larger family size without leaving your neighborhood.

There are several reasons to remodel a home using passive solar features. The most common are: to save money, to save energy, and for a more comfortable lifestule.

\section{Environmental Trends}

Passive solar technqques have been available for 10 years, but there has been limited activity in the marketplace because design tools have not been easy to use. In recent years, the public has become increasingly aware of environmental issues such as acid rain, ozone depletion, and global warming. This has created a new market demand for energy efficient. environmentally sensitive housing.

The evidence of the trend has been appearing in many disparate places. "Green Advertising." companies promoting their products with enviromental messages, is now seen on prime time TV.

Recycling is becoming mandated by mundpalities all over the coutry. Natural foods are available and highlighted in chain food stores. Magazines are devoting special issues to enviromental topics. Mitchell Rouda wrote, "The Green Movement is not a fad but a seachange."

The rapld change in consumer behavior is compelling for remodelers who are on the cutting edge of the industry. A variety of market research studles have shown similar finding: $79 \%$ of Americans consider themselves environmentalists: $76 \%$ want business to do more to protect the environment, and research shows that consumers are willing to pay up to $20 \%$ more for environmentally safe products. A recent study found 
over $85 \%$ of home buyers would pay up to $\$ 1.800$ for energy features if they provided good econorrics.

"American Demographics" reported on a study conducted by the Roper Organization. The study breaks the public into five environmental types. Of the five groups, the two that are most environmentally aware are dominated by the market sector most likely to remodel their house: affluent, college educated, and female. This $22 \%$ of the population tends to be professionals and executives. live in urban areas, already recycle, read product labels, and contribute to environmental organizations. They are always on the lookout for ways to individually contribute to helping clean up the environment. But they are not willing th sacrifice comfort and conventence.

A third group representing $26 \%$ of the adult population polled are also educated and tend to hold professional jobs. They are the group most likely to take action on their own rather than expecting government to pass regulations and laws. Forty percent belleve that individuals can successfully clean up the environment.

The other two categories tend to be from the more socially and economically disadvantaged segment of the population. Sixty-nine percent have a high school education or less, and are blue collar workers.

In conclusion, energy efficient, passive solar design is a perfect "product" to respond to the emerging market demarid for environmentally safe products. Well designed and built additions and remodelling projects can provide win-win business opportunities for astute companies. The "first win" is the client can save money on energy bills. The "second win" is the planet is protected from pollution, acid rain, and depletion of the ozone. In addition, it creates a great new marketing opportunity for those companies that seize the mornent and ride the wave of the "Greening of America."

How does passive solar design fit into all of this? Passive solar uniquely blends amenity value with energy conservation. It provides beautuful sunlit spaces whlle creating increased comfort. Trends in home design include increased glazing and when installed properly, can reduce energy use which minimizes the impact on the environment. Passive solar is the natural solution to home heating and cooling and appeals to the segment of the public that is demanding more natural foods. products and furnishings. The biggest advantage is that the investment in good passive solar design keeps on paying off as long as the individual owns the house. Year after year the home owner reaps tax-free cash flow from the energy savings and the aesthetic spaces increase the resale value of the home. Why passive solar? It's the smart market of the 90's for remodelers.
According to NAHB's

Remodeler's Council. residential ;. modeling generally has kept pace with new residential construction since 1984. However, during the downturns in the housing market, remodeling activity remains steady or declines less.

\section{Consumer Trends}

According to the NAHB, the most sought features in a house are $21 / 2$ baths or more, a twoor three-car garage, masonry siding, a security system, at least one fireplace, bay windows, French doors, built-in shelves, hardwood floors, high grade carpeting, an eat-in kitchen, a dishwasher, a double sink, wood finished cabinets, a built-in microwave oven, a walk-in pantry, and a garbage disposal - all of which are easily added to a home once it is already built.

Many home owners are concerned that adding a passive solar feature to their house is difficult or not within their price range. On the contrary, remodeling a home with passive solar features can be done quickly and inexpensively. In some cases, passive solar remodeling requires some physical modification of the home. Although costs can vary significantly, the homeowner should expect to invest between a few hundred and a few thousand dollars. In a well designed passive remodel this initial cost can be offset in a short period of time by savings in fuel costs. 
Passive solar has become a win-win solution for the remodeler and home owner. Passive solar addresses the concerns about preserving the environment, creates a new marketing opportunity, and has a very positive impact on the planet. Many of the early passive solar houses, bullt in the 1970's were custom designed for people who were sensitive to energy and environmental concerns. In many cases, the owner, designer, and bullder were all the same person. Therefore, the designer-occupant paid careful attention to the energy features in their home throughout the years. These guidelines provide information about increasing the energy efficiency of homes and applying refinements of that knowledge.

\section{The Guidelines}

Some principles of passive solar design remain the same in every climate. But the important thing about passive solar is it makes better use of the opportunities in a house's surroundings. So, many fundarnental aspects of the passive solar house's design will depend on the conditions in a small local area, and even on the features of the site itself. Many of the suggestions in this section apply specifically to Baltimore. Maryland, but there is also information in each section of the booklet which will be useful in anv climate.

- Part One introduces Passive Solar Design Strategies, and presents the performance potential of several different passive solar systems in the Baltimore climate. Although in practice many factors will affect actual energy performance, this information will give you a general idea of how various systems will perform in your area.

- Part Two discusses the basic concepts of passive solar design and remodel: what the advantages of passive solar are, how passive solar relates to other kinds of energy conservation measures, how the primary passive solar systems work, and what the remodeler's most important considerations should be when evaluating and using different passive solar strategies.

Part Three gives more specific advice about techniques for suntempering, direct gain systems, thermal storage mass walls and sunspaces, and for natural cooling strategles to help offset air-conditioning needs.

The Example Tables in Part Three are developed based on the calculations which appear on the four guideline Worksheets. On these worksheets, there are several summary energy performance indicators. The example tables present these summary indicators for several typical passive solar strategles. The three primary performance indicators are:

- Conservation Performance Level

- Auxdliary Heat Performance Level

- Summer Cooling Performance Level
Each of these indicators will be discussed in the next section which introduces the guideline worksheets.

All of the examples in part three are based on adding an 800 sf addition to an exdsting 1500 sf home. Insulation levels typical of existing homes in Baltimore are assumed. The remodel adds space on the south and east of the home. The addition of attic insulation and generai air tightening (caulking. weatherstripping, etc.) is included in the remodel. In these examples, the energy savings are achieved by combining the above ener $5 y$ conservation strategies with specific passive solar features and through the use of a ceiling fan to cut some of the air conditioning load.

The general target for the remodel is to bring the existing structure up to the standard of a reasonably energy-efficient house based on a 1987 National Association of Home Builders study of housing characteristics. divided into seven different regions. The exdsting structure used for Baltimore, Maryland is from the 3,500-5,000 heating degree-days region. The house is assumed to be built over an unheated basement, because this is typical in Maryland.

The examples show how to achieve energy-use reductions using two basic strategles:

I Suntempering: increasing south-facing glazing to a maximum of $7 \%$ of the house's total tloor area, but without adding thermal mass (energy storage) beyond what is already in the framing, standard floor 
coverings and gypsum wallboard and celling surfaces. Insulation levels are also increased.

- Passive Solar: using three different design approaches: Direct Gain, Sunspace, and Thermal Storage Wall, and increased levels of insulation.

For all strategles, the energy savings indicated are based on the assumption that the energyefficient design and construction guldelines have been followed.

The Guidelines section has been kept as brief and straightforward as possible, but more detalled information is avallable if nceded. Additional information sources are identified in the References. Also included at the end of this book are a brief Glossary, a summary of the Example Tables for Baltimore, Maryland, and two pages explaining some of the background and assumptions behind the Guidelines and Worksheets called Technical Basis for the Remodeling Guidelines.

\section{The Worksheets}

The Worksheets are specifically tailored for Baltimore, Maryland, and are a very important part of this package because they allow you to compare un paper different passive solar strategles or combinations of strategies. and the effect that changes will have on the overall performance of the house.

The most effective way to use the Worksheets is to make multiple copies before you fill them out the first time. You can then use the Worksheets to calculate several dufferent designs. For instance, you could first calculate the performance of the basic house you remodel, then flll out Worksheets for that house plus added insulation plus a sunspace, and then for a third possibility such as an addition with a Thermal Storage Wall.

The Worksheets provide a way to calculate quickly and with reasonable accuracy how well a design is likely to perform in four key ways: how well it will conserve heat energy; how much the solar features will contribute to its total heating energy needs; how comfortable the house will be; and how much the house's annual cooling load (need for air conditioning) will be.

The Worksheets are supported by "look-up" tables containing pre-calculated factors and numbers for the local area. Some of the blanks in the Worksheets call for information about the house - for example, floor area, projected area of passive solar glazing, and so forth. Other blanks require a number from one of the tables for example, from the Solar System Savings Fraction table or from the Heat Gain Factor table.

The Worksheets allow calculation of the following performance indicators:

- Worksheet I: Conservation Performance Level: determines how well the house's basic energy conservation measures (insulation, sealing, caulking, etc.) are working to prevent unwanted heat loss in the winter. The bottom line of this
Worksheet is a number measuring heat loss in British thermal units per square foot per year (Btu/sf-yr) - the lower the heat loss, the better.

\section{- Worksheet II: Auxillary} Heat Performance Level: determines how much heat has to be supplied (that is, provided by the heating system) after takdng into account the heat contributed by passive solar. This worksheet arrives at a number estimating the amount of heating energy the house's non-solar heating system has to provide in Btu/yr-sf. Again, the lower, the better.

\section{- Worksheet III: Thermal Mass/Comfort: determines} whether the house has adequate thermal mass to assure comfort and good thermal performance. Worksheet III calculates the number of degrees the temperature inside the house is likely to vary, or "swing", during a sunny winter day without the heating system operating. A well-designed house should have a temperature swing of no more than 13 degrees, and the less the better.

\section{worksheet IV: Summer Cooling Performance Level:}

indicates how much air conditioning the house will need in the summer (it is not. however, intended for use in sizing equipment, but as an indication of the rectictions in annual cooling load rade possible by the use of natural cooling). The natural cooling guidelines should make the house's total cooling load - the bottom line of this Worksheet, in 
Btu/yr-sf - smaller than in a "conventional" housc.

So, the Worksheets provide you with four key numbers indicating the projected performance of the various designs you are evaluating.

- The Worked Example: To assist in understanding how the design strategles outlined in the Gutdelines affect the overall performance of a house, a worked example is included. The example house, constructed of materials and design elements typical of the area, is a one story, single-family $1,116 \mathrm{sf}$ home to which a 696 sf passive solar remodel is to be added. Various design features, such as direct gain spaces, sunspaces, increased levels of insulation and thermal mass, are included to llustrate the effects combined systems have on the performance of a house. Also, many features are covered to demonstrate how various conditions and situations are addressed in the worksheets. A description of the design features, along with the house plans, elevations and sections, are included for additional support information.

\section{Passive Solar Performance Potential}

The energy performance of passive solar strategies varies significantly, depending on climate, the specific design of the system, and the way it is bullt and operated. Of course, energy performance is not the only consideration. A system which will give excellent energy performance may not be as marketable in your area or as easily adaptable to your designs as a system which saves less energy but fits your other needs.

In the following table, several different passive solar systems are presented along with two numbers which indicate their performance. The Percent Solar Savings is a measure of how much the passive solar system is reducing the house's need for purchased energy. For example. the Percent Solar Savings for the Exdsting Structure is $3.8 \%$, because even in a non-solar house, the south-facing windows are contributing some heat energy.

The Yleid is the annual net heating energy benefit of adding the passive solar system, measured in Btu saved per year per square foot of additional south glazing.

The figures given are for a single-story house with a basement. The Existing Structure has 45 sf of southfacing glazing. For the purposes of this example, the

Suntempered house has 105 sf of south-facing glass, and each passive solar system has 145 sf.

The energy savings presented in this example assume that all the systems are designed and built according to the suggestions in these Guidelines. Iis also important to remember that the figures below are for annual net heating benefits. The natural cooling section in Part Three glves advice about shading and other techniques which would make sure the winter heating benefits are not at the expense of higher summer coolling loads.

In these performance examples, the estimated total annual heating use for the base case house is 89.2 Million Btu. Just to pick from one of the alternatives, the energy conscious sunspace remodel has an estimated total annual heating use of 84.1 Million Btu. With the combined performance of conservation and passive solar features, the remodeled home uses less energy (even including the additional square footage) than the original existing home.

Please note that throughout the Guidelines and Worksheets the glazing areas given are for the actual net area of the glass itself. A cominon rule of thumb is that the net glass area is $\mathbf{8 0}$ percent of the rough frame opening. For example, if a south glass area of $100 \mathrm{sf}$ is desired, the required area of the rough frame opening would be about 125 sf. 
Performance Potential of Passive Solar Strategles for Remodeling In Baltimore, Maryland

1,500 st Single Story House with 800 sf Addition

Case

House with Addition

(45 sf of south-facing double glass)

Suntempered

(105 sf of south-facing double glass)

Direct Gain (145 st of south glass)

Double Glass

Sunspace

(145 sf of south glass)

Thermal Storage Wall - Masonry/Concrete

(145 sf of south glass)

9.3

50,926

10.0

57,410

In these pertormance comparisons, the 800 st remodel includes upgrading the attic insulation throughout the home, air tightening to 0.5 air changes per hour, upgraded insulation in all newly constructed walls and the stated passive soiar features.

\section{Establishing the Energy Performance of the Existing Structure}

In order to estimate the potential to save energy in a remodeling project using passive solar design techniques, it is important to first make some assessment of the extsting residence. An indtial audit of the house will alert you to specific opportunitles such as glazing replacement combined with a space addition which could satisfy the home owner's remodeling desires and enhance the energy efficiency of the whole structure. Many home owners will appreciate recelving an "energy scorecard" on the current state of their residence as part of your discussion of remodeling opportunities.

Finally, to take best advantage of these Remodeler Guidelines. certain basic information is needed on the existing house in order to fill out the worksheet contained in this package.

There are inany sources of information avallable to you on carrying out a residential energy audit. Under some circumstances you may want to refer to your state energy office to learn about local agencies and utilities providing this service at a low cost directly to the home owner. You may want to learn more about such diagnostic techniques as the use of a blower door and thermography to rapidly locate air leaks and other general sources of heat loss in a structure. 
If you carry out the survey yourself. you may use the Guideline worksheets (particularly Worksheet I) to determine what information is required. In general, you will attempt to determine rough areas of windows, walls, and other elements of the envelop of the house. In addition, you will make rough estimations of existing insulation levels and air tughtness in the house.

A common approach in conducting an audit is to quickly sketch each facade of the house and then note on these sketches the rough dimensions of wall, windows, etc. as you make measurements. You also can note construction details (face brick vs wood siding, for example) and landscaping features which might have impact on possible solar additions. Hidden features such as insulation levels may be determined by a quick look in the attic, or crawlspace.

Occasionally you may be able to determine wall insulation thickness. This may be done by pulling off switch plates and looking into the wall cavity or cutting into the wall cavity in an inconspicuous plare such as a closet.

Lackdng more specific information, you may guess insulation levels based on the year of construction. Ceillings typically have RII insulation if built before 1970 . You may assume the following wall insulation levels based on the year of construction:

a) before 1960, RO - R7;

b) 1962-73, R7; c) 1973-80, R11:

d) after 1980, R13-R16. Table A accompanying the Remodeler Guidelines Worksheets may be used for estimating the effecttve $R$-value of various type of windows, doors, and wall sections.

Air infiltration is an important component of heat loss in most exdsting structures. For estimation purposes, a moderately tight exdsting house will have an atr change rate of approximately one change per hour. A moderate to leaky house (with loose windows, little or no weatherstripping. foundation cracks, loose siding. etc.) will have an air change rate of two to three changes per hour. 


\section{Part Two: Basics of Passive Solar}

1. Why Passive Solar? More than a Question of Energy

2. Key Concepts: Energi Conservation, Suntempering, Passive Solar

3. Improving Conservation Performance

4. Mechanical Systems

5. South-Facing Glass

6. Thermal Mass

7. Orientation

8. Site Planning for Solar Access

9. Interior Space Planning

10. Putting it Together: The House as a System 


\section{Why Passive Solar? More than a Question of Energy}

Houses today are more energyefficient than ever before. However, the vast majority of exdsting houses ignore a lot of energy saving opportunities opportunities avallable in the sunlight falling on the house, in the landscaping, breezes and other natural elements of the site, and opportunities in the structure and materials of the house itself, which, with thoughtful design, could be used to collect and use free energy.

Passive solar (the name distinguishes it from "active" or mechanical solar technologies) is simply a way to take maximum advantage of these opportunities.

home owners are also increasingly sophisticated about energy issues, although the average home owner is probably much more famillar with insulation than with passtve solar. Very few people percelva their own household energy bills as getting smaller - quite the opposite. So a house with significantly lower monthly energy costs year-round will have a strong market advantage over a comparable house down the street. no matter what international oil prices may be. Such homes also may be qualified for relaxed mortgage lending qualification through energy efficiency mortgage programs.

But there are many different ways to reduce energy bills, and some are more marketable than others. For instance, adding insulation can markedly improve energy-effictency - but added insulation is invisible to the prospective home buyer. A sunny, open living area lit by south-facing windows, on the other hand. may add a key selling point. Windows in general are very popular with home owners, and passive solar can make windows energy producers instead of energy liabilities.

Another example: highefficiency heating equipment can account for significant energy savings - but it won't be as much fun on a winter morning as breakfast in a bright. attractive sunspace.

The point is not that a remodeler should choose passive solar instead of other energyconserving measures. The important thing is that passive solar can add not only energyefficiency, but also very saleable amenities like comfort, attractive interiors, curb appeal and resale value.
In fact, in some local markets, builders report that they don't even have to make specific reference to "passive solar".

They just present their houses as the state of the art in energy-efficiency and style, and they use passive solar as a part of the overall package.

The U.S. Department of Energy and the National Renewable Energy Laboratory (NREL) conducted extensive national surveys of passive solar homes, home owners and potential buyers. Some key findings:

- passive solar homes work - they generally require an average of about $30 \%$ to $40 \%$ less energy for heating than "conventional" houses, with some houses saving much more.

occupants of passive solar homes are pleased with the performance of their homes lover $90 \%$ "very satisfied"), but they rank the comfort and pleasant living environment as just as importani (in some regions, more important) to their

\section{Advantages of Passive Solar}

Energy performance: Lower energy bills all year-round

- Attractive llving environment: large windows and views, sunny interiors, open floor plans

- Comfort: quieter (no operating noise), strong construction, warmer in winter, cooler in summer (even during a power failure)

- Value: high owner satisfaction and greater resale value

- Low Maintenance: durable, reduced operation and repairs

- Investment: independence from future rises in fuel costs, will continue to save money long after any initial costs have been recovered

- Environmentai Concerns: clean, renewable energy to combat growing concerns over global warming, acid rain, energy imports, and ozone depletion 
satisfaction, and in their decision to buy the house, as energy considerations.

- passive solar home owners and lenders perceive the resale value of passive solar houses as high.

\section{Key Concepts:} Energy Conservation, Suntempering,

\section{Passive Solar}

The strategies presented here for enhancing energy fall into three general categories:

- Energy Conservation: more efficient insulation levels, control of air infultration, glazing type and location, mechanical equipment, and appliances.

- Suntempering: a moderate use of passive solar techniques; modestly increasing south-facing window area, but without adding thermal mass.

- Passive Solar: going beyond conservation and suntempering to a complete system of collection, storage and use of solar energy: using more south glass, adding significant thermal mass, and taking steps to control and distribute heat energy throughout the house.

What is immediately clear is that these categories overlap. For instance, a good energy-conservation package is the necessary starting point of all well-designed suntempered and passive solar houses. There's no use collecting solar energy if it is immediately lost through leaky windows or poor insulation.

In the sanne way, many of the measures that often are considered part of suntempering or passive solar can help a house conserve energy even if no actual "solar" features are planned. Such features include orfenting the house to take advantage of summer breezes, landscaping for natural cooling. or facing a long wall of the house south.

The essential elements in a passive solar house are southfacing glass and thermal mass.

In the simplest terms, a passtve solar system collects solar energy through southfacing glass and stores heat in materials with a high thermal capacity for storing heat (e.g.. brick, concrete masonry, concrete slab, tile, water). Beyond modest sun tempering. the more south-facing glass is used in the house, the more thermal mass must be provided. Otherwise, the solar system will not perform as expected and overheating might occur.

With too much glass and/or insufficient mass, solar energy can work too well. and the house can be uncomfortably hot even on a winter day. Without sufficlent heat storage, design for proper natural cooling becomes more difficult.

Although the concept is simple, in practice the relationship between the amount of glazing and the amount of mass is complicated by many factors, and has been a subject of considerable study and experiment. From a comfort and energy standpoint, it would be difficult to add too much mass. Thermal mass will hold warmth longer in winter and keep houses cooler in summer. But using more thermal mass adds cost. Thus, adding too much mass for just thermal storage purposes can be unnecessarlly expensive while providing relatively little added benefits.

The following sections of the Guidelines discuss the size and location of glass and mass, as well as other considerations which are basic to both suntempered and full passive solar houses: improving conservation performance; mechanical systems; orientation; site planning for solar access; interior space planning; and taking an integrated approach to the house as a total system. 


\section{Improving Conservation Performance}

The techniques described in this section relate to Worksheet I: Conservation Performance Level, which estima'e $s$ the house's heat loss. The energy conservation measures that reduce heat loss also help reduce the house's need for air conditioning.

The most important measures for improving the house's basic ability to conserve the heat generated either by the sun or by the house's converitional heating system are in the following areas:

\section{- Non-solar glazing \\ - Insulation \\ - Air infiltration}

\section{Insulation}

Adding insulation to walls, floors, cellings, roof and foundation improves their thermal resistance (R-value) their resistance to heat flowing into or out of the house.

A quality job of installing the insulation can have almost as much effect on energy performance as the R-value, so careful construction supervision is important. An inspection just before the drywall is hung identifies improvements which are easy at that time but will make a big difference in the energy use of the home for years to come.
The thermal resistance of celling/roof assemblies, walls and floors is affected not only by the R-value of the insulation itself, but also the resistance of other elements in the construction assembly framing, sheathing, interior drywall, and so on. The Worksheets include tables that show Equivalent Construction $R$-Values which account for these and other effects. For instance, ventilated crawlspaces and unheated basements provide a buffering effect which is accounted for in the Worksheet tables. Using precalculated values can reduce the possiblity of error and makes using the Worksheets easier.

With attics, framing effects are minimized if the insulation covers the celling joists, either by using blown-in insulation or by running an addittonal layer of batts in the opposite direction of the ceiling Joists. Ridge and/or eave vents are needed for ventilation. In addition, you need to provide at least one square foot of open venting area for each 300 square feet of attic area.

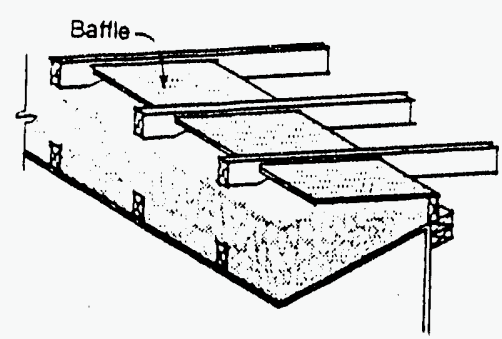

Insulation In an Attlc Insulation should extend over the top ceiling joists and ventilation should be provided at the eaves.

In framed celling/roof assemblies (like with cathedral cellings), an insulating sheathing over the top decking will increase the R-value. 
Slab edge insulation should be at least two feet deep. extending from the surface of the floor. Matertals for slab edge insulation should be selected for underground durabllity. One matertal with a proven track record is extruded polystyrene. Exposed insulation should be protected from physical damage by attaching a protection board. for instance, or by covering the insulation with a protective surface like stucco.

A heated basement's walls should be fully insulated to at least four feet below grade, but the portion of the wall below that depth only needs to be insulated to about half the R-value of the upper portion. Insulation can be placed on the outside surface of the wall, or on the inside surface of the wall, or in the cores of concrete masonry units if used.

If the basement walls are insulated on the outstde, the materials should be durable underground, and exposed insulation should be protected from damage. In the case of a finished basement or walk-out basement, placing insulation on the interfor may be less costly than insulating the extericr of the foundation wall.

\section{Checkllst for Minimizing Air Leakage}

$\checkmark$ Tighten seals around windows and doors, and add weatherstripping around all openings to the outside or to unconditioned rooms;

" Caulk around all windows and doors before drywall is hung; seal all penetrations (plumbing, electrical, etc.);

Insulate behind wall outlets and/or plumbing lines in exterior walls;

$\checkmark$ Caulk under headers and sills;

Chink spaces between rough openings and millwork with insulation, or for a better seal, fill with non-expanding foam;

- Seal larger openings such as ducts into attics or crawlspaces with taped polyethylene covered with insulation;

Locate continuous vapor retarders located on the warm side of the insulation (barriers sealing the openings for mechanical closets used as return plenums or chases is vital). Air barrier materials should be at least five timies more permiable;

$\checkmark$ Install dampers and/or glass doors on fireplaces; combined with outside combustion air intake;

- Install backdraft dampers on all exhaust fan openings;

$\checkmark$ Caulk and seal the joint between ihe basernent slab (or the slab on grade) arid the basement wall;

$\checkmark$ Remove wood grade stakes from slabs and seal;

$\checkmark$ Cover and seal sump cracks;

- Close core voids in top of block foundation walls;

$\checkmark$ Control concrete and masonry cracking;

Use of air tight drywall methods are also acceptable (see Reference 11);

Employ appropriate radon miligation techniques (see References 13 and 14). 


\section{Air Infiltration}

Sealing the house carefully to reduce air infiltration - air leakage - is as necessary to energy conservation as adding insulation. Air will flow rapidly through cracks and crevices in the walls, floors, and ceillings.

The tightness of houses is generally measured in the number of air changes per hour (ACH). A good, comfortable. energy-efficient house, having the features described in the checklist on this page, will have approxdmately 0.35 to 0.50 air changes per hour under normal winter conditions.

Increasing the tightness of the house beyond that rnay improve the energy performance, but it may also create problems with indoor air quality, moisture build-up, and inadequately vented fireplaces and furnaces. Some kind of additional mechanical ventilation - for example, small fans, heat pump heat exchangers, integrated ventilation systems or air-to-air heat exchangers - will probably be necessary to avold such problems in houses with less than $0.35 \mathrm{ACH}$ (calculated or measured).

\section{Non-Solar Glazing}

South-facing windows are considered snlar glazing. The south windows in any house contribute some solar heat energy to the house's heating needs - whether it's a significant, usable amount or hardly worth measuring will depend on design, location and other factors which are dealt with later under the discussions of suntempering and passive solar systems.

North windows in almost every climate lose significant heat energy and gain very little useful sunlight in the winter. However, they can provide safe egress, asthetic views, and diffuse sunilght. Relatively oversized east and west windows are likely to increase air conditioning needs unless heat gatn is minimized with careful attention to shading.

But most of the reasons people wani windows have very little to do with energy, so the best design will often be a good workdng compromise between energy efficiency and other benefits, such as bright living spaces and views.

You know it is time to replace your window when you notice some kind of fault in the window or structural fallure occurs due to corroston or rot. Windows are also replaced because they are poor insulators or they don't accommodate functional changes in the use of a new room. Newly installed windows should meet or exceed the current energy codes. A tight window that reduces air infiltration is important for energy efficiency.

Although windows provide a necessary view to the outside. they also admit lif,nt into the adjacent room and allow the penetration of radiant heat energy. Windows transmit more energy than any other part of a house. Windows are known for having poor insulating qualities and therefore allow comparatively large amounts of heat to escape back to the outside unless deterred by some sort of insultating device.

Double-glazing of all nonsolar glazing is advisable. Low-e glazing on all non-solar windows may be an especially useful solution because some low-e coatings can insulate in winter and shield against unwanted heat gain in summer.

Manufacturers often provide $R$-values for their windows (the thermal performance of glazing can be expressed either as an Rvalue or its reciprocal, U-value; here all thermal performance values are given in terms of $R$ value). A chart is also pruvided with the Worksheets to show approxdmate window R-values for various types. (The Equivalent Glazing R-Vaiue pertains to the entire rough frame opening of the window.) You should use manufacturer data if available.

North facing windows should be used with care. Sometimes views or the diffuse northern light are desirable, but in general north-facing windows should not be large. Larger north-facing windows should have high insulation value, or 
R-value. Since north windows recelve relatively little direct sun in summer, they do not present much of a shading problem. So If the choice were between an average-sized north-facing window and an east or westfacing window, north would actually be a better choice. considering both summer and winter performance.

East facing windows catch the morning sun. They do not receive enough to provide significant energy but, unfortunately, usually enough to cause potential overheating problems in summer. If the views or other elements in the house's design dictate east windows, shading shouid be done with particular care.

West facing windows may be the most problematic, and there are few shading systems that will be effective enough to uffset the potential for overheating from a large west-facing window. Glass with a low shading coefficient may be one effective approach - for example, tinted glass or some types of low-e glass which provide some bulltin shading while. The cost of properly shading both east and west windows should be balanced against the benefits.

As many windows as possible should be kept operable to allow for natural ventilation in spring, fall, and summer. (See also Orientation, page 17 . Recommended Non-South Glass Guidelines, page 34 , and Shading, page 35)

\section{Mechanical Systems}

The passive solar features in the house and the mechanical heating, ventllating and air conditioning systems (HVAC) will interact all year round and so the most effective approach will be to design the system as an integrated whole. HVAC design is, of course, a complex subject, but the three areas below are particularly worth noting in passtve solar houses:

- System Sizing. Mechanical systems are often oversized for the relatively low heating loads in well-insulated passive solar houses. Oversized systems will cost more in the first place, and will cycle on and off more often. wasting energy. The back-up systems in passive solar houses should be sized to provide $125 \%$ of the heating or cooling load on the design day, but no larger. Comparing estimates on system stzes from more than one contractor is a good idea.

Since the mechanized systems of most houses are oversized, when passive solar addittons are incorporated into the retrofit design, the exdsting mechanical systems may be adequate for heating and cooling. In some cases, particularly when large additions are used as the retrofit strategy. supplemental mechanical systems may be necessary in the addition. It is wise to make the necessary calculations to confirm the system size in any case.
- Nir,ht Setback. Clock thermostats for automatic night setback are usually very effective - but in passive solar systems with large amounts of thermal mass (and thus a large capacity for storing energy and releasing it during the night), night setback of the thermostat greater than 5 to $8^{\circ} \mathrm{F}$ may not save very much energy.

- Ducts. One area often neglected but of key importance to the house's energy performance is the design. location, and installation quality of the ducts. Both the supply and return ducts should be located within insulated areas. or well insulated if they run in cold areas of the house, and well sealed at the joints. The joints where the ducts turn up into exterior walls or penetrate the celling should be particularly tught and caulked.

In the National Association of Home Builders' Energy-Efficient House Project, all the rooms were fed with low, interior wall air supplies, as opposed to the usual placement of registers under windows at the end of long runs. This resulted in good comfort and energy performance.

The performance of even the most beautifully designed passive solar house can easlly be undermined by detalls like uninsulated ducts, or by overlooking other basic energy conservation measures. 


\section{South-Facing Glass}

South-facing solar glass is a key component of any passive solar system. The system must include enough solar glazing for good performance in winter. However, unwanted solar gains from the glazing needs to be controlled to avold increasing the cooling requirements. The design of solar glazing must also be carefully related to the amount of thermal mass.

Suntempered houses require no additional thermal mass beyond that already in the wallboard. framing and furnishings of a typical house. Passive solar houses typically require additional thermal mass for best performance.

There are three types of limits on the amount of southfacing glass that can be used effectively in a house. The first is a limit on the amount of glazing for suntempered houses. Research has shown this limit (without adding thermal mass) to be $7 \%$ of the house's total floor area.
For direct gain systems in passtve solar houses, the maxdmum useful amount of south-facing glazing is $12 \%$ of total floor area, regardless of how much additional thermal mass is provided. Further detalls about the most effective sizing of south glass and thermal mass for direct gain systems are provided in Part Three.

The third limit on southfacing glass is the total of all passtve solar systems combined. which should not exceed $20 \%$ of total floor area. Using more south glass than this limit could lead to overheating even in winter despite using mass.

For example, a passtve solar system for a 1,500 sf house might combine 72 sf of direct gain glazing with 58 sf of sunspace glazing for a total of 130 sf of solar glazing, or $5 \%$ of the total floor area, well within the direct gain limit of $7 \%$ and the overall limit of $20 \%$. For a design like this, thermal mass would be required both in the house and within the sunspace.
The Natural Cooling guidelines in Part Three include recommendations on the window area that should be operable to allow for natural ventilation.

When the solar glazing is tylted (Installed at a slope), its winter effectiveness as a solar collector usually increases. However, tulted glazing can cause serlous overheating in the summer if it is not shaded very carefully. Some bullding codes require more expensive tempered safety glass for these installations. If overhead sunlight is desired such as in a greenhouse, operable sky lights are a useful alternative. Ordinary vertical glazing is easier to shade, less likely to overheat, less susceptible to damage and leakdng, and so is almost always a better yearround solution. 


\section{Thermal Mass}

Some heat storage capacity, or thermal mass, is present in all houses. This includes the gypsum ceiling and wall board in the framing. typical furnishings, and floor coverings. In suntempered houses, this modest amount of mass is usually sufficient for the modest amount of south-facing glass.

But more thermal mass is required in true passtve solar houses, and the questions are: not only how much, but what knd, how thick, what color, and where it should be located?

The preferred therrnal mass in a passive solar system is usually a conventional construction material such as brick, cast concrete, concrete masonry, concrete slabs, or tye. and is usually placed in the floor or interior walls. If the mass components also perform a dual function, like acting as a separation wall or bearing wall. they can be more cost-effective.

Water has a significantly higher unit themnal storage capaci y than concrete or masonry. Water tubes and units called "water walls" are commercially avallable (general recommendations for these systems are included in the section on Thermal Storage Wall systems). Water systems must be secured to prevent leaks and over turning. Algacides are added to this water for reducing unwanted growth of organisms.
The thermal storage capacity of a given material depend on the material's conductivity. specific heat and density. Most of the concrete and masonry materials typically used in passtve solar have similar specific heats. Therrinal conductivity tends to increase with increasing density. So the major factor affecting performance is density. Generally, the higher the density the better.
The destgn issues related to thermal mass depend on the passive system type. For sunspaces and thermal storage wall systems, the required mass of the system is included in the design itself. For direct gain, the added mass must be within the rooms recetving the sunlight. The sections on Direct Gain Systems, Sunspaces and Thermal Storage Walls contain more information on techniques for sizing and locating thermal mass in those systems.

\begin{tabular}{|c|c|c|c|}
\hline \multicolumn{4}{|c|}{ Heat Storage Properties of Construction Materials } \\
\hline Material & $\begin{array}{l}\text { Specific Heat } \\
\left(\mathrm{Ib}-\mathrm{-}^{-} \mathrm{F}\right)\end{array}$ & $\begin{array}{l}\text { Density } \\
\left(\mathrm{lb} / \mathrm{t} \mathrm{t}^{3}\right)\end{array}$ & $\begin{array}{c}\text { Heat Capacity } \\
(\text { Etu/ir-sf- } F)\end{array}$ \\
\hline Poured Concrete & $0.019 \cdot 0.24$ & $120-150$ & $2.0-2.5$ \\
\hline $\begin{array}{l}\text { Clay Masonry } \\
\text { Molded Brick } \\
\text { Extruded Brick } \\
\text { Pavers }\end{array}$ & $\begin{array}{l}0.19 \\
0.19 \\
0.21\end{array}$ & $\begin{array}{l}120-130 \\
125-135 \\
130-135\end{array}$ & $\begin{array}{l}2.0-2.2 \\
2.1-2.3 \\
2.2-2.3\end{array}$ \\
\hline $\begin{array}{l}\text { Concrete Masonry } \\
\text { Block } \\
\text { Brick } \\
\text { Pavers }\end{array}$ & $\begin{array}{l}0.21 \\
0.22 \\
0.22\end{array}$ & $\begin{array}{c}80-140 \\
115-140 \\
130-150\end{array}$ & $\begin{array}{l}1.3-2.3 \\
1.9-2.3 \\
2.2-2.5\end{array}$ \\
\hline Gypsum Wallboard & 0.26 & 50 & 0.83 \\
\hline Water & 1.00 & 62.4 & 5.2 \\
\hline Wood, soft & 0.39 & $22 \cdot 41$ & $0.72 \cdot 1.33$ \\
\hline
\end{tabular}




\section{Orientation}

The ideal orientation for solar glazing is within 5 degrees of true south. This orlentation will provide maximum performance. Glazing orlented to within 15 degrees of true south will perform almost as well, and orlentations up to 30 degrees off - although less effective - will still provide a substantial level of solir contribution.

in Baltimore, magnetic north as indicated on the compass is actually 7 Degress West of true north, and this should be corrected for when orienting south glazing.

When glazing is oriented more than 15 degrees off true south, not only is winter solar performance reduced, but summer air conditioning loads also significantly increase, especially as the orientation goes west. The warmer the climate, the more east- and west-facing glass will tend to cause overheating problems. In general, southeast orlentations present less of a problem than southwest.

In the ideal situation, the house should be orjented eastwest and so have its longest wall facing south. But as a practical matter, if the house's short side has good southern exposure it will usually accommodate sufficient glazing for an effective passive solar system, provided the heat can be transferred to the northern zones of the house.

\section{Siting the Addition}

The basic objective of site planning for maximum energy performance is to allow the south side as much unshaded exposure as possible during the winter months.

As discussed previously, a good solar orlentation is possible within a relatively large southern arc, so the flexdbility exdsts to achleve a workable balance between energy performance and other important factors such as the slope of the site, the individual house plan, the direction of prevalling breezes for summer cooling, the views, the street lay-out, and so on.

But planning for solar access does place some restrictions on the site. One must consider the site when remodeling a home with passive solar features. Solar heating systems are dependent upon the avallability of the sun. The best orientation for solar collection is due south. Not all houses have the appropriate solar access or orientation. Therefore, in considering the solar retrofit process, one must determine the extent of solar avallability.

It is important to determine which surrounding elements or obstructions will prevent the sun from reaching the selected area. Some deciduous trees will allow a high percentage of solar penetration through their branches in winter months and could be left alone. Once you have an idea of the amount of sun avallable and a knowledge of where it comes from and when. then you know which is the best location of your house for the solar collection component.

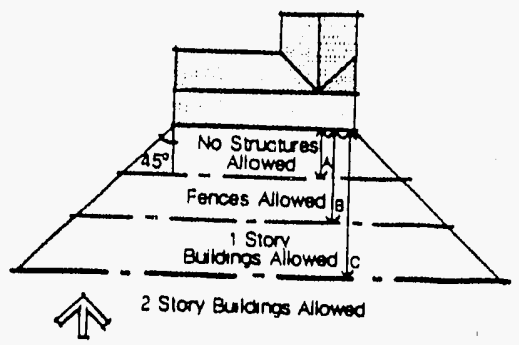

Ideal Solar Access

Buildings, trees or other obstructions should not be located so as to shade the south wall of solar buildings. At this latitude, $A=13 \mathrm{th}$., $B=22 \mathrm{ft}$. and $C=51 \mathrm{ft}$.

Once again, there is an ideal situation and then some degree of flexdbility to address practical concerns. Ideally, the glazing on the house should be exposed to sunlight with no obstructions within an arc of 60 degrees on either side of true south, but reasonably good solar access will still be guaranteed if the glazing is unshaded within an arc of 45 degrees. The figure above shows the optimum situation for providing unshaded southern exposure during the winter. See also the figure on page 35 showing landscaping for summer shade.

Of course, not all lots are large enough to accommodate this kind of optimum solar access, so it's important to carefully assess shading patterns on smaller lots to make the best compromise.

Protecting solar access is easiest in subdivisions with streets that run within 25 degrees of east-west, because all lots will elther face or back up to south. Where the streets run north-south, creation of east- 
west cul-de-sacs will help ensure solar access.

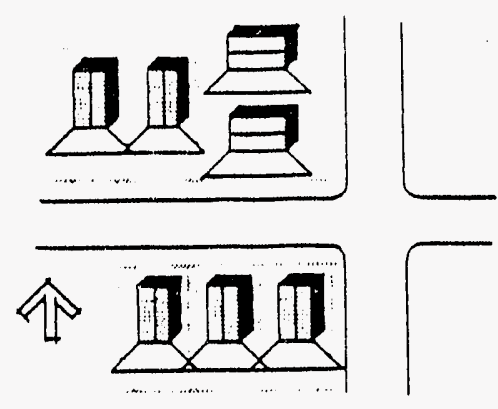

Solar Access

Solar access may be provided to the rear yard, the side yard or the front yard of solar homes.

\section{Interior Space Planning}

Planning room lay-out by considering how the rooms will be used in different seasons, and at different times of day, can save energy and increase comfort. In houses with passive solar features, the lay-out of rooms - and interlor zones which may include more than one roon 1 - is particularly Important.

When additions are planned. living areas and other highactivity rooms should be located on the south side to benefit from the solar heat. The closets, storage areas. garage and other less-used rooms can act as buffers along the north side, but entry-ways should be sheltered away from the wind.

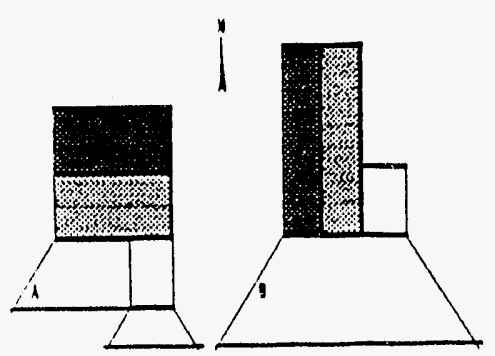

Placement of Additions A. Addition blocks solar access of exisitng south wall.

B. Addition adds to solar access of existing south wall.
Other ideas from effective passive solar houses:

- Orlenting internal mass walls as north-south partitions that can be "charged" on both sides thus makdng maxdmum use of the mass. The dual functionality of such walls can boost the cost-effectiveness of the construction.

- Using east-west partition walls for thermal mass, but make sure the interlor space isn't divided into a south zone which may get too warm and a north zone which may get too cold.

- Using thermal storage walls (see page 30): the walls store energy all day and slowly release it at night, and can be a good alternative to ensure privacy and to buffer noise if the home's south side faces the street:

- Collecting the solar energy in one zone of the house and transporting it to another by fans or natural convection through an open floor plan. - Providing south-facing clerestories to "charge" north zones, and to introduce daylight to inner zones.
Interior Space Planning

Living and high activity spaces should be located on the south. 


\section{Putting it}

\section{Together: The House}

\section{as a System}

Many different factors will affect a house's overall performance, and these factors all interact: the mechanical system, the insulation, the house's tightness, the effects of the passive solar features, the appliances, and, very importantly, the actions of the people who live in the house. In each of these areas, changes are possible which would improve the house's energy performance. Some energy savings are relattvely easy to get. Others can be more expensive and more difficult to achieve, but may provide benefits over and above good energy performance.

A sensible energy-efficient house uses a combination of techniques.

In fact, probably the most important thing to remember about designing for energy performance in a way that will also enhance the comfort and value of the house is to take an integrated approach, keeping in mind the house as a total system. On the the following page is a basic checklist for energy-efficient design. These techniques are dealt with in more detail, including their impact in your location, in Part Three. 


\section{Checkllst for Good Design}

1. Bullding assessment: Regardless of the existing house orientation and design, some options for increased energy efficieny are avallable. An energy audit or evaluation of the existing structure using the worksheets will help you choose the best options avallable.

2. Upgraded levels of insulation: It is possible, of course, to achieve very high energy-efficiency with a "superinsulated" design. But in many cases, one advantage of passive solar design is that energy-efficiency can be achieved with more modest increases in insulation, and good natural lighting is maintained.

On the other hand, if very high energy performance is a priority - for example, in areas where the cost of fuel is high - the most cost-effective way to achieve it is generally through a combination of high levels of insulation and passive solar features. These guidellnes will help you achieve a proper "mix".

3. Reduced air inflitration: Air tightness is not only critical to energy performance, but it also makes the house more comfortable. Air infiltration rates may be determined by using a blower door test.

Indoor air quality is an important issue but is too complex for a complete discussion here. The suntempered and passive solar houses built according to the guidelines provide an alternative approach to achleving improved energy efficiency without requiring air quality controls such as air to air heat exchangers, which would be needed if the house were made extremely airtight. By the same token, passive solar homes are not necessarily more "leaky" than conventional ones.

4. Proper window sizing and location: Even if the total amount of glazing is not changed, rearranging its location alone can often lead to significant energy savings at little or no added cost. Some energy-conserving designs minimize window area on all sides of the house - but it's a fact of human nature that people like windows, and windows can be energy producers if located correctly. Too few or too small windows may even represent a safety hazard for fire egress.

5. Selection of glazing: Low-emissivity (low-e) glazing types went from revolutionary to commonplace in a very short time, and they can be highly energy-efficient choices. But the range of glazing possibilities is broader than that, and the choice will have a significant impact on energy performance. Using different types of glazing for windows with different orientations is worth considering for maximum energy performance; for example, using heat-rejecting glazing on west windows, high R-value glazing for nurth and east windows, and clear double-glazing for higher transmission on the south. The building retrofit should consider appropriate replacement windows.

6. Proper shading of windows: If windows are not properly shaded in summer - either with shading devices, or by high-performance glazing with a low shading coefficient - the air conditioner may have to work overtime and some of the energy savings of the winter may be canceled out. Even more important, unwanted solar gain can reduce comtort.

7. Addition of thermal mass: Adding effective thermal mass - for example, concrete slabs, masonry walls, brick fireplaces, brick or concrete paved floors, etc. - can greatly improve the comfort in the house, holding heat better in winter and keeping rooms cooler in summer. In a passive solar system, of course, properly sized and located thermal mass is essential.

8. Interior design for air distribution: When an addition is used in a remodel, the mechanical distribution in the addition must be tied into the existing system or supplementary mechanical equipment must be installed to service the addition. The systems supply air rate (in cubic feet per minute - CFM) must be checked to ensure effective delivery of air to the rooms

9. Selection and proper sizing of mechanical systems, and selection of energy-efficient appliances: High-performance heating, cooling and hot water systems are extremely energy-efficient, and almost always a good investment. Mechanical equipment should have at least a 0.80 Annual Fuel Utilization Efficiency (AFUE).

Well-insulated passive solar homes will have much lower energy loads than conventional homes, and furnaces and air-conditioning units should be sized accordingly. Oversized systems will cost more and reduce the house's performance.

For guides to the selection of energy-efficient appliances, see References 13 and 14 . The installation of a new, more efficient mechanical system may be an ideal option when retrofitting the structure to optimize the efficiency and adequately condition both existing spaces and additions. 
Part Three: Strategies for Improving Energy Performance in Baltimore, MD

1. The Example Tables

2. Suntempering

3. Direct Gain

4. Sunspaces

5. Thermai Storage Wall

6. Combined Systems

7. Natural Cooling Guidelines 


\section{The Example Tables}

In the following sections of the Guidelines, the primary passive solar systems - Suntempering. Direct Gain, Thermal Storage Walls and Sunspaces - are described in more detall.

As part of the explanation of each system, an Example table is provided. The Examples present the following information about an Exdsting Structure:

- Insulation levels (cellings, walls, and floors):

- Insulation added to the perimeter of the basement walls; - Tightness (measured in air changes per hour, $\mathrm{ACH}$ );

- The amount of glass area on each side (measured as a percentage of floor area: the actual square footage for a 2,300 sf house is also given as a reference point);

The "percent solar savings" (the part of a house's heating energy saved by the solar features):
- Four numbers corresponding to those on the Worksheets: Conservation, Auxdllary Heat, Thermal Mass/Comfort, and Cooling Performance (see page 4). The Example tables then show how the house design could be changed due to a remodel and compared to the Exdsting Case.

There are, of course, other ways to achieve energy savings than those shown in the Examples. The Examples are designed to show an effective integration of strategles. Using any of these combinations would result in excellent performance in your area. However, they are general indications only, and using the Worksheets will give you more information about your specific design.

The Example assumes a 1,500 sf house to which an 800 sf remodel has been added, but the percentages apply to a house of any size or configuration.
The R-values indicated in the Example tables are, of course. approxdmate and are intended to show how incremental improvements can be achieved. The R-values for the conventional remodel indicate existing construction. The Rvalues for the energy conscious remodel apply to new or modified portions of the home. Also note that $R$-values are for assembly equivalents - that is, for an entire construction assembly, not fust for the cavity insulation itself, and these equivalents take into account framing and buffering effects.

Other assumptions are noted for each Example. However, one more general assumption is important to note here. When the Examples were calculated, it was assumed that natural cooling strategies such as those described in these Guidelines were used, particularly in the very high-performance systems. The greater the percentage reduction in heating energy needs using passive solar design, the more shading and natural cooling were assumed.

All the example tables are summarized on pages 54 and 55. 


\section{Suntempering}

Suntempered and passive solar houses both:

- begin with good basic energy-conservation.

- take maximum advantage of the building site through the right orientation for year-round energy savings, and

- have increased south-facing glass to collect solar energy.

Suntempering is the simplest passive solar system, and refers to modest increases in windows on the south side.

No additional thermal mass is necessary, only the "free mass" in the house - the framing, gypsum wall-board and furntshings.

In a "conventional" house, about $25 \%$ of the windows face south, which amounts to about $3 \%$ of the house's total floor area. In a suntempered house, the percentage is increased to a maximum of about $7 \%$.

The energy savings are more modest with this system, but suntempering is a very low-cost strategy.

Of course, even though the necessity for precise sizing of glazing and thermal mass does not apply to suntempering (as long as the total south-facing glass does not exceed $7 \%$ of the total house floor area), all other recommendations about energyefficient design such as the basic energy conservation measures. room lay-out, siting, glazing type and so on are still important for performance and comfort in suntempered homes.

\begin{tabular}{|c|c|c|}
\hline \multirow[b]{2}{*}{$\begin{array}{l}\text { R-Values } \\
\text { Ceiling/Roof } \\
\text { Walls } \\
\text { Basement Wall } \\
\text { Glass }\end{array}$} & \multicolumn{2}{|c|}{$\begin{array}{l}\text { Examples of Heat Energy Savings } \\
\text { Suntempered } \\
0 \text { sf Single Story House with } 800 \text { sf Addition }\end{array}$} \\
\hline & $\begin{array}{r}15 \\
7 \\
2 \\
.9\end{array}$ & $\begin{array}{r}38 \\
22 \\
2 \\
3.1\end{array}$ \\
\hline Alr Changes/Hour & 0.75 & 0.50 \\
\hline $\begin{array}{l}\text { Glass Area (percen } \\
\text { West } \\
\text { North } \\
\text { East } \\
\text { South }\end{array}$ & $\begin{array}{l}\text { area) } \\
2.0 \% \\
2.0 \% \\
2.0 \% \\
2.0 \%\end{array}$ & $\begin{array}{l}2.0 \% \\
2.0 \% \\
2.0 \% \\
4.6 \%\end{array}$ \\
\hline Solar System Size (square feet) & 45 & 105 \\
\hline Percent Solar Savings & $3 \%$ & $7 \%$ \\
\hline $\begin{array}{l}\text { Performance (Btu/y } \\
\text { Conservation } \\
\text { Auxiliary Heat } \\
\text { Cuoling }\end{array}$ & $\begin{array}{c}59,642 \\
58,099 \\
7,082\end{array}$ & $\begin{array}{c}40,702 \\
37,794 \\
4,407\end{array}$ \\
\hline \multicolumn{3}{|c|}{$\begin{array}{l}\text { Summary: Insulation values and tightness of the house (as measured in } \\
\text { ACH) have been increased. Attic insulation has been increased } \\
\text { throughout. For both cases, the R-values of the existing structure (other } \\
\text { than the ceiling) are the same before and after the remodel. R-values for } \\
\text { energy conscious case apply only to new or modified portions of the } \\
\text { home. The window area on the south has been increased. }\end{array}$} \\
\hline
\end{tabular}

Baltimore, MD 


\section{Direct Gain}

The most common pass!ve solar system is called direct gadn: sunlight through south-facing glazing falls directly into the space to be heated, and is stored in thermal mass incorporated into the floor or interior walls.

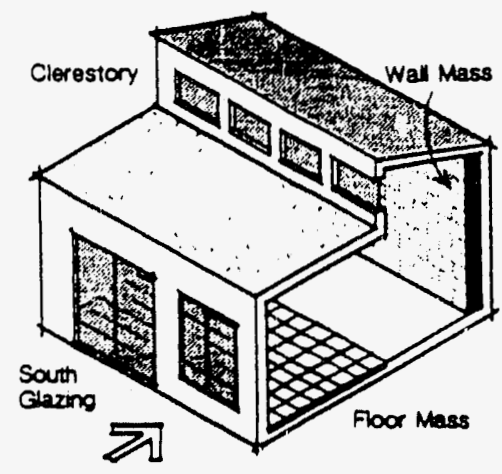

\section{Direct Gain}

Direct gain is the most common passive solar system in residential applications

\section{Sizing Limit}

Total direct gain glass area should not exceed about $12 \%$ of the house's floor area. Beyond that, problems with glare or fading of fabrics are more likely to occur, and it becomes more difficult to provide enough thermal mass for year-round comfort.

So the total south-facing glass area in a direct gain system should be between $7 \%$ (the maxdmum for suntempered houses) and $12 \%$, depending on how much thermal mass will be used in the design, as discussed below.

\section{Glazing}

Double glazing is recommended for direct gain glazing in

Baltimore. Night insulation also improves energy perfurmance dramatically. In fact, covering the windows at night or on cloudy days with the equivalent of R-4 shades or other material will save almost as much energy as with R-9 material. But studies have shown that only relattvely few homeowners will be dillgent enough about operating their night insulation to achieve those savings. Energy-efficient glazing, on the other hand, needs no operation. and therefore is a more conventent and reliable option.

\section{Thermal Mass}

Thermal mass can be incorporated easily into slab-ongrade type bulldings as either floor covering, walls or veneers over interior walls. If the mass is placed in the floor, it will be much more effective if sunlight falls directly on it.

Effective materials for floors include painted. colored or virylcovered concrete, brick (face brick or pavers have even higher density than ordinary bullding brick), quarry tile, and darkcolored cer mic tile.

For houses bullt with crawlspaces or basements, the incorporation of stgnificant amounts of heavy thermal mass is a little more difficult. Thermal mass floor coverings over basements. crawlspaces and lower stories would generally be limited to thin set tile or other thin mass floors.
When more mass is required, the next best option is for interior walls or interlor masonry fireplaces. When evaluating costs, the dual function of mass walls should be remembered. They often serve as structural elements or for fire protection as well as for thermal storage. Another option is to switch to another passive solar system type such as attached slab-ongrade sunspaces or thermal storage walls bullt directly on exterfor foundation walls.

Sunlt thermal mass floors should be relatively dark in color, to absorb and store energy more effectively. However, mass walls and cellings should be light in color to help distribute both heat and light more everly. 
Ratio of Glass to Mass. The following procedure can be used to determine the maximum amount of direct-gain glazing for a given amount of thermal mass. If the amount of direct-gain glazing to be used is already known, thermal mass can be added until this procedure produces the desired proportions:

- Start with a direct gain glass area equal to $7 \%$ of the house's total floor area. As noted above. the "free mass" in the house will be able to accommodate this much solar energy.

- An additional 1.0 sf of direct gain glazing may be added for every 5.5 sf of uncovered, sunlit mass floor. Carpet or area rugs will serlously reduce the effectiveness of the mass. The maxdmum floor mass that can be considered as "sunlit" may be estimated as about 1.5 times the south window area.

- An additional 1.0 square foot of direct gain glazing may be added for every $40 \mathrm{sf}$ of thermal mass in the floor of the room. but not in the sun.

- An additional 1.0 square foot of direct gain glazing may be added for each $8.3 \mathrm{sf}$ of therral mass placed in the wall or celling of the room. Mass in the wall or celling does not have to be located directly in the sunilght, as long as it is in the same room, with no other walls between the mass and the area where the sunlight is falling.
More south-facing glazing than the maximum as determined here would tend to overheat the room, and to reduce energy performance as well.

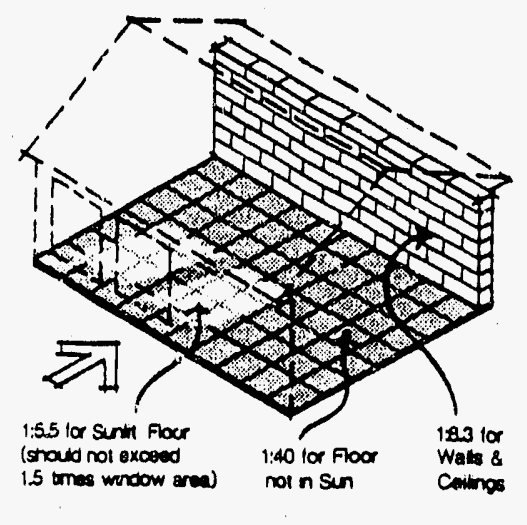

Mass Location and Effectiveness Additional mass must bo provided for south facing glass over $7 \%$ of the floor area. The ratio of mass area to additional glass area depends on its location within the direct gain space.

Thickness. For most materials, the effectiveness of the thermal mass in the floor or interior wall increases proportionally with thickness up to about 4 inches. After that, the effectiveness doesn't increase as significantly.

A two-inch mass lloor will be about two-thirds as effective in a direct gain system as a four-inch mass floor. But a six-inch mass floor will only perform about eight percent better than a four. inch floor.

The following figure shows the effectiveness of thermal mass in relation to density and thickness. The vertical axis shows how many square feet of mass area are needed for each added square foot of direct gain.
As you can see, performance increases start leveling off after a few inches of thermal mass.

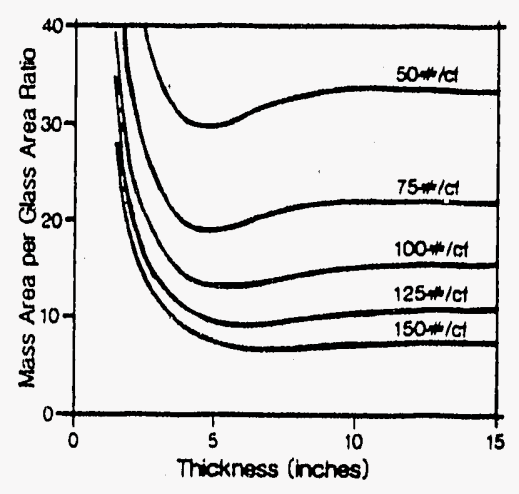

Mass Thickness

The effectiveness of thermal mass depends on the density of the material and trickness. This graph is for wall or ceiling mass in the direct gain space.

\section{Worksheet III: Thermal}

Mass/Comfort should be used to make sure the house has adequate thermal mass. 


\begin{tabular}{|c|c|c|}
\hline \multirow[b]{2}{*}{$\begin{array}{l}\text { R-values } \\
\text { Ceillng/Roof } \\
\text { Walls } \\
\text { Basement Wall } \\
\text { Glass }\end{array}$} & \multicolumn{2}{|c|}{$\begin{array}{l}\text { Eat Energy Savings } \\
\text { ar-Direct Galn } \\
\text { touse with } 800 \text { st Addition }\end{array}$} \\
\hline & $\begin{array}{r}15 \\
7 \\
2 \\
.9\end{array}$ & $\begin{array}{c}38 \\
22 \\
2 \\
3.1\end{array}$ \\
\hline Alr Changes/Hour & 0.75 & 0.50 \\
\hline $\begin{array}{l}\text { Glass Area (percent of } t \\
\text { West } \\
\text { North } \\
\text { East } \\
\text { South }\end{array}$ & $\begin{array}{r}\text { (area) } \\
2.0 \% \\
2.0 \% \\
2.0 \% \\
2.0 \%\end{array}$ & $\begin{array}{l}2.0 \% \\
2.0 \% \\
2.0 \% \\
6.3 \%\end{array}$ \\
\hline $\begin{array}{l}\text { Added Thermal Mass } \\
\text { Percent of Floor Area }\end{array}$ & $0.0 \%$ & $11.5 \%$ \\
\hline $\begin{array}{l}\text { Solar System Size (squa } \\
\text { South Glass } \\
\text { Added Thermal Mass }\end{array}$ & $\begin{array}{c}45 \\
0\end{array}$ & $\begin{array}{l}145 \\
264\end{array}$ \\
\hline Percent Solar Savings & $3 \%$ & $9 \%$ \\
\hline $\begin{array}{l}\text { Performance (Btu/yr-sf) } \\
\text { Conservation } \\
\text { Auxiliary Heat } \\
\text { Cooling }\end{array}$ & $\begin{array}{c}59,642 \\
58,099 \\
7,082\end{array}$ & $\begin{array}{c}40,595 \\
36,838 \\
3,200\end{array}$ \\
\hline $\begin{array}{l}\text { Summary: Insulation va } \\
\text { ACH) have been increas } \\
\text { throughout. R-values for } \\
\text { R-values for energy cons } \\
\text { the home. } \\
\text { South-facing glazing has } \\
\text { added mass area is asst } \\
\text { treating the } 800 \text { sf additi }\end{array}$ & $\begin{array}{l}\text { tightness of the } \\
\text { c insulation has } \\
\text { tional remodel a } \\
\text { ase apply to nev } \\
\text { ubstantially incre } \\
\text { be six times the } \\
\text { stand-alone spa }\end{array}$ & $\begin{array}{l}\text { house (as measured in } \\
\text { been increased } \\
\text { apply to existing structure. } \\
\text { w or modifled portions of } \\
\text { eased. For this example, } \\
\text { excess south glass area } \\
\text { ce. }\end{array}$ \\
\hline
\end{tabular}




\section{Sunspaces}

The sunspace is a very popular passive solar feature, adding an attractive living space as well as improved energy performance. There are many variations on the bastc theme of the sunspace. and the possibillties for sunspace design are extraordinarlly diverse (References 17 through 20 include specific design ideas).

The sunspace concept used in these Guldelines can be used year-round, will provide most or all of its own euergy needs, and may contribute to the energy needs of the rest of the house as well.

Sunspaces are referred to as "Isolated gain" passive solar systems, because the sunlight is collected in an area which can be closed off from the rest of the house. During the day, the doors or windows between the sunspace and the house can be opened to circulate collected heat, and then closed at night. and the temperature in the sunspace allowed to drop.

The sunspace should not be on the same heating system as the rest of the house. A well designed sunspace will probably need no mechanical heating system, but if necessary, a small fan or heater may be used to protect plants on extremely cold winter nights.

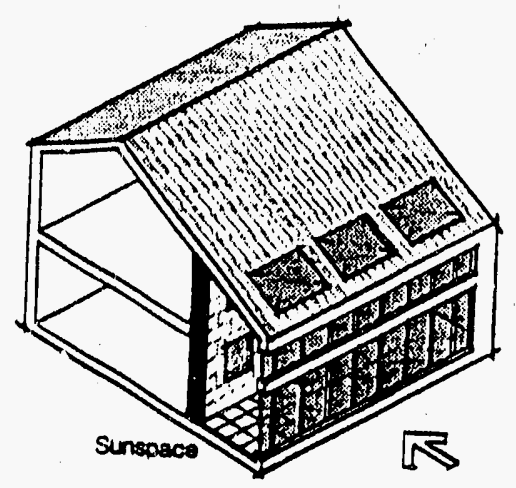

Sunspeces

Sunspaces provide usetul passive solar heating and also provide a valuable amenity to homes.

\section{Thermal Mass}

A sunspace has extensive southfacirig glass, so sufficient thermal mass is very important. Without it, the sunspace is liable to be uncomfortably hot during the day, and too cold for plants or people at night.

However, the temperature in the sunspace can vary more than in the house itself. so about three square feet of four inch thick thermal mass for each square foot of sunspace glazing should be adequate. With this glass-to-mass ratio, on a clear winter day a temperature swing of about $30^{\circ} \mathrm{F}$ should be expected.
The sunspace floor is a good location for thermal mass. The mass floors should be dark ir color. No more than $15-25 \%$ of the floor slab should be covered with rugs or plants. The lower edge of the south-facing windows should be no more than six inches from the floor or the planter bed to make sure the mass in the floor recetves sufficlent direct sunlight. If the windows sills are higher than that, additional mass will have to be located in the wall.

Another good location for thermal mass is the common wall (the wall separating the sunspace from the rest of the house). Options for the common wall are discussed in more detail below.

Water in various types of containers is another form of energy storage often used in sunspaces.

\section{Glazing}

Clear, double-glazing is recommended for sunspaces. Adding the second pane makes a large improvement in energy savings. Triple-glazing or low-e coatings, on the other hand, will further improve comfort, but will have little effect on energy savings.

Windows on the east and west walls should be small (no more than $10 \%$ of the total sunspace floor area) but they are useful for cross-ventilation.

Like tilted or sloped glazing, glazed roofs can increase solar gain, but they can also present big overheating problems and become counter-productive. If either glazed roofs or tilted 
giazing are used in the

sunspace, special care should be taken to make sure they can be effectively shaded during the summer and, if necessary, on sunny days the rest of the year, too. The manufacturers of sunspaces and glazing are developing products with better ability to control both heat loss and heat gain (for example, roof glazing with low shading coefficients, shading treatments and devices, etc.).

You'll note that in the Performance Potential chart on page 6 , sunspaces with glazed roofs or sloped glazing perform very well. This analysis assumes effective shading in the summer. If such shading is not economical or marketable in your area, you should consider using only vertical glazing, and accepting somewhat less energy performance in winter.

\section{Common Wall}

There are a number of options for the sunspace common wall. In mild climates, and when the sunspace is very tightly constructed, an uninsulated frame wall is probably adequate. However, insulating the common wall to about R-10 is a good tdea, espectally in cold climates. An insulated common wall will help guard against heat loss during prolonged cold, cloudy periods, or if the thermal storage in the sunspace is insufficient.

Common wall constructed of masonry may be used for thermal mass. If the solid masonry is approximately 4 to 8 inches thick. Another option is to construct a masonry veneer over a frame wall.

Probably the most important factor in controlling the temperature in the sunspace, and thus keeping it as comfortable and efficient as possible, is to make sure the exterior walls are tightly constructed and well-insulated.
Some solar energy may be transferred from the sunspace to the rest of the house by conduction through the common wall if it is made of thermal mass. But energy is mainly transferred by natural convection through openings in the common wall - doors, windows and/or vents.

- Doors are the most common opening in the common wall. If the only openings in the wall are doorways, the total area of the door should be at least $15 \%$ of the sunspace south-glass area. - Windows will also provide light and views. The window area in the common wall should be no larger than about $40 \%$ of the entire common wall area. If only windows are used, the operable area should be about $25 \%$ of the sunspace's total south glass area.

Adding openings to the common wall will generally require the addition of structurai headers if the common wall is a bearing wall. Construction should only proceed with appropriate shoring. 


\section{Summer ventilation}

The sunspace must be vented to the outside to avold overheating in the summer or on warm days in spring and fall. A properly vented and shaded sunspace can function much like a screened-in porch.

Operable windows and/or vent openings should be located for effective cross-ventilation. and to take advantage of the prevalling summer wind. Low inlets and high outlets can be used in a "stack effect", since warm air will rise. Total ventilation area should be at least $15 \%$ of the total sunspace south glass areas.

Where natural ventllation is insufficient, or access to natural breezes is blocked, a small, thernostat-controlled fan set at about $76^{\circ} \mathrm{F}$ will probably be a useful addition.

\section{Examples of Heat Energy Savings \\ Passive Solar-Sunspace}

1,500 sf Single Story House with an 800 st Addition with Sunspace

$$
\text { Energy }
$$

R-Values

Ceilling/Roof

Walls

Basement Wall

Conventional Conscious

Glass

Remodel Remodel

$\begin{array}{lll}\text { Alr Changes/Hour } & 0.75 & 0.50\end{array}$

Glass Area (percent of total floor area)

West

North

East

South (windows)

Sunspace

$\begin{array}{ll}3.0 \% & 2.0 \% \\ 3.0 \% & 4.0 \% \\ 3.0 \% & 4.0 \% \\ 2.0 \% & 2.0 \% \\ 0.0 \% & 4.3 \%\end{array}$

Solar System Size (square feet)

South Glass

Sunspace Glass

Sunspace Thermal Mass

$\begin{array}{rr}15 & 38 \\ 7 & 22 \\ 2 & 2 \\ .9 & 3.1\end{array}$

Percent Solar Savings

Performance (Btu/yr-sf)

Conservation

38

22

3.1

Auxiliary Heat

Cooling

$\begin{array}{cc}45 & 45 \\ 0 & 100 \\ 0 & 300\end{array}$

$3 \% \quad 10 \%$

Summary: Insulation values and tightness of the house (as measured in $\mathrm{ACH}$ ) have been increased. Attic insulation has been increased

throughout. $R$-values for conventional remodel apply to existing structure. R-values for energy conscious case apply to new or modified portions of the home. The sunspace assumed here is semi-enclosed (surrounded on three sides by conditioned rooms of the house, as In Figure SSC1 of the worksheets), with vertical south glazing. The common wall is a thermal mass wall made of masonry. Sunspace glazing is assumed to be double. 


\section{Thermal Storage Wall}

The Thermal Storage Wall also sometimes referred to as a Trombe wall or an indirect gain system - is a south-facing glazed wall, usually butlt of heavy masonry, but sometimes using water containers or phase change matertals. The masonry is separated from the glazing only by a small alr space.

Sunlight is absorbed directly into the wall instead of into the living space. The energy is then released into the living space over a relatively long period. The time lag varies with different materials, thicknesses and other factors, but typically, energy stored in a Thermal Storage Wall during the day is released during the evening and nighttime hours.

The outside surface of a thermal storage wall should be a very dark color - an

absorptance greater than 0.92 is recommended.

Because the summer sun does not shine directly in. summer heat gain from a Thermal Storage Wall is much less - roughly $80 \%$ less - than from a comparable area of direct gain glazing.

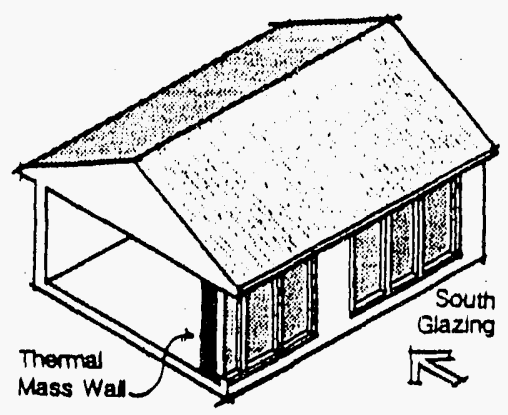

Thermal Storago Wall

A thermal storage wall is an effective passive solar system, especially to provido nighttime heating.

A masonry Thermal Storage Wall should be solld, and there should be no openings or vents either to the outside or to the living space. Although vents to the living space were once commonly bullt into Thermal Storage Walls, expertence has demonstrated that they are ineffective. Vents between the Thermal Storage Wall and the house tend to reduce the system's night time heating capability, and to increase the temperature fluctuation in the house. Vents to the outside are simularly ineffective, and do little to reduce summer heat gains.

The example demonstrates passive solar performance of the structure with an 800 sq. $\mathrm{ft}$. addition designed with a thermal storage wall. Existing masonry walls may be transformed into thermal stroage walls by adding glazing to the extertor of the wall. Adequate support for the glazing will be a critical design and construction requirement. Exdsting frame walls may be replaced with thermal storage walls if there is adequate foundation width and strength to support the masonry wall.

\section{Glazing}

Double glazing is recommended for Thermal Storage Walls unless a selective surface is used. In this case, single glazing performs about the same as double glazing.

The space between the glazing and the thermal mass should be one to three inches.

\section{Selective Surfaces}

A selective surface is a spectal adhesive foll applled to the exterior side of the mass of Thermal Storage Walls.

Selective surfaces absorb a large percentage of solar radiation but radiate very little heat back to the out-of-doors (low emittance).

To be effective, selective surfaces must be applied carefully for $100 \%$ adhesion to the mass surface.

In Baltimore, Maryland, a selective surface will improve Thermal Storage Wall performance by about $60 \%$.

\section{Mass Material and Thickness}

In general, the effectiveness of the Thermal Storage Wall will increase as the density of the material increases.

The optimum thickness of the wall dopends on the density of the material chosen. The following chart indicates the recommended thickness of Thermal Storage Walls made of various materials. 


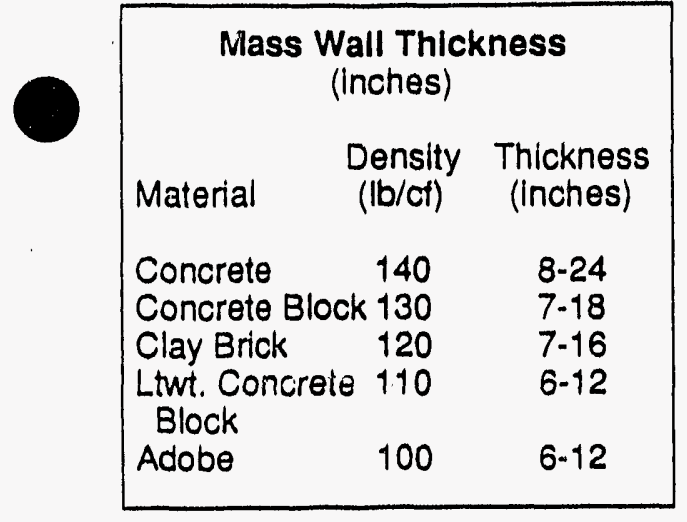

\section{Water Walls}

Water provides about twice the heat storage per unit volume as masonry, so a smaller volume of mass can be used. In "water walls" the water is in light, rigid containers. The containers are shipped empty and eastly installed. Manufacturers can provide information about durability, installation. protection against leakage and other characteristics. At least 30 pounds ( 3.5 gallons) of water should be provided for each square fout of glazing. This is equivalent to a water container about six inches thick, having the same area as the glazing.

\begin{tabular}{|c|c|c|}
\hline \multicolumn{3}{|r|}{$\begin{array}{l}00 \text { sf Addition } \\
\text { Energy }\end{array}$} \\
\hline $\begin{array}{l}\text { R-Values } \\
\text { Celling/Roof } \\
\text { Walls } \\
\text { Basement Wall } \\
\text { Glass }\end{array}$ & $\begin{array}{r}15 \\
7 \\
2 \\
.9\end{array}$ & $\begin{array}{c}38 \\
22 \\
2 \\
3.1\end{array}$ \\
\hline Alr Changes/Hour & 0.75 & 0.50 \\
\hline $\begin{array}{l}\text { Glass Area (percent o } \\
\text { West } \\
\text { North } \\
\text { East } \\
\text { South } \\
\text { Thermal Storage Wall }\end{array}$ & $\begin{array}{r}\text { area) } \\
2.0 \% \\
2.0 \% \\
2.0 \% \\
2.0 \% \\
0.0 \%\end{array}$ & $\begin{array}{l}2.0 \% \\
2.0 \% \\
2.0 \% \\
2.0 \% \\
4.3 \%\end{array}$ \\
\hline $\begin{array}{l}\text { Solar System Size (so } \\
\text { South Glass } \\
\text { Thermal Storage Wall }\end{array}$ & $\begin{array}{l}0 \\
0\end{array}$ & $\begin{array}{c}0 \\
100\end{array}$ \\
\hline Percent Solar Saving & $3 \%$ & $11 \%$ \\
\hline $\begin{array}{l}\text { Performance (Btu/yr-s } \\
\text { Conservation } \\
\text { Auxiliary Heat } \\
\text { Cooling }\end{array}$ & $\begin{array}{c}59,642 \\
58,099 \\
7,082\end{array}$ & $\begin{array}{c}40,595 \\
35,844 \\
1,860\end{array}$ \\
\hline \multicolumn{3}{|c|}{$\begin{array}{l}\text { Summary: Insulation values and tightness of the house (as measured in } \\
\text { ACH) have been increased. Attic insulation has been increased } \\
\text { throughout. R-values for conventional remodel apply to existing structure. } \\
\text { R-values for energy conscious case apply to new or modified portions of } \\
\text { the home. In the case of a Thermal Storage Wall, south-facing glazing and } \\
\text { thermal mass are incorporated together. The estimates here assume a } \\
12 \text {-inch thick concrete Thermal Storage Wall with a selective surface and } \\
\text { single glazing. }\end{array}$} \\
\hline
\end{tabular}




\section{Combined Systems 7. Natural Cooling Guidelines}

Although the previous sections have presented separate discusstons of four different systems, it isn't necessary to choose one and only one system. In fact, passive solar features work well in combination.

For example, direct gain works very well in conjunction with a sunspace or thermal storage wall. Since thermal storage walls release energy more slowly than direct gain systems, they are useful for supplying heat in the evening and at night, whereas the direct gain system works best during the day. Although using a sunspace, therrnal storage wall and direct gain system in the same house may result in excellent performance, such combinations do require a large south-facing area, and careful design to make sure the systems are well-integrated with each other and with the house's mechanical system.
The term "natural cooling" is used here to describe techniques which help a house stay cool in summer but which require little or no energy. Natural cooling techniques work to help reduce air-conditioning, not replace it.

These techniques are useful not only in passive solar houses, but in "conventional" houses as well. The strategies outlined below - attention to the location, size and shading of glazing, using the opportunities on the site for shading and natural ventilation, and using fans - can reduce atr conditioning needs and increase comfort even if the house has no passive solar heating features.

But shading is particularly important in passive solar houses, because the same features that collect sunlight so effectively in winter will go right on collecting it in summer resulting in uncomfortably hot rooms and big air conditioning bills - unless they are shaded and the house is designed to help cool itself.
Fortunately, many of the features that help maintain comfort and reduce energy needs in winter also work well in summer. For instance, additional thermal mass performs well year-round. Masonry materlals are equally effective in staying cool and storing heat. If mass surfaces can be exposed to cool nighttime temperatures - a technique referred to as "night ventilation" - they will help the house stay cooler the next day. A Callfornia utllity found during studies of small test bulldings that on hot summer days the workmen at the facllity always ate lunch in the masonry test building because it stayed much cooler than any of the others. (See Reference 9)

The additional insulation that increases winter performance will also work to improve summer performance by conserving the conditioned air as well as reducing heat gain. And some low-e windows and other glazing with high $\mathrm{R}$-value can help shield against unwanted heat gain in summer. 
The potential of some natural and low-energy cooling strategies is shown in the following table for Baltimore.

Worksheet IV: Cooling Performance Level indicates the total annual cooling load. and so can give an Idea of how the passive solar features increase the cooling load and how much reduction is possible when natural cooling techniques are used.

It should be noted that the Cooling Performance numbers presented in the Examples for each passive solar strategy assume that the design also includes the recommended natural cooling techniques. This is especially true of the higher percentage reductions; these assume better heating performance, but also better shading and other natural cooling strategies.

\section{Cooling Potential}

Existing Structure 7,082 Btu/yr-st

Strategy

$$
\text { Energy }
$$

Savings

(Btu/yr-sf)

Percent

Savings

No Night Ventilation 1

without ceiling fans

with celling fans

Night Ventilation 1

without ceiling fans

with ceiling farns

$\begin{array}{cc}0 & 0 \% \\ 2,820 & 23 \%\end{array}$

High Mass² without ceiling fans with ceilling fans

1 With night ventllation, the house is ventilated at night when temperature and humidity conditions are favoriable.

2 A "high mass" building is one with a thermal mass area at least equal to the house floor area. 


\section{Glazing}

As mentioned earlier, poorly placed windows can increase air conditioning loads dramatically. It is generally best in terms of energy performance to carefully size non-solar glazing as indicated in the following table.

\begin{tabular}{|lc|}
\hline \multicolumn{2}{|c|}{ Recommended Non-south } \\
Glass Guldelines \\
Orieniation & $\begin{array}{c}\text { Percent } \\
\text { of Total } \\
\text { Floor Area }\end{array}$ \\
East & $4 \%$ \\
North & $4 \%$ \\
West & $2 \%$ \\
\hline
\end{tabular}

As mentioned earlier, westfacing windows present particularly difficult shading problems. If glazing is added above the levels indicated, the need for shading will become even more critical.

Cooling loads increase as window area increases. This relationship for Baltimore is shown in the following table for each of the cardinal window orlentations. For instance when a square foot of west area is added or subtracted. the annual cooling load increases or decreases by $67,790 \mathrm{Btu} / \mathrm{yr}-\mathrm{sf}$.

\begin{tabular}{|c|c|}
\hline \multicolumn{2}{|c|}{ Added Window Cooling Load } \\
\hline Orientation & $\begin{array}{l}\text { Added Annual } \\
\text { Coolling Load } \\
\text { (Btu/yr-sf) }\end{array}$ \\
\hline $\begin{array}{l}\text { North } \\
\text { East } \\
\text { South } \\
\text { West } \\
\text { Skyllights }\end{array}$ & $\begin{array}{c}34,540 \\
63,170 \\
55,470 \\
67,790 \\
123,560\end{array}$ \\
\hline \multicolumn{2}{|c|}{$\begin{array}{l}\text { These values are based on } \\
\text { double glass with a shading } \\
\text { coefflicient of } 0.88 \text {. When glazing } \\
\text { with a different shading } \\
\text { coefficient is used the values may } \\
\text { be scaled proportionally. }\end{array}$} \\
\hline
\end{tabular}

These numbers can be reduced by shading as described in the next section.

Using special glazing or window fllms that block solar transmission (low shading coefficient) is an option often used in particularly hot climates, but the more effective they are at blocking sunlight. the less clear they are, as a rule, and so they may interfere with desirable views. It is important to note, however, that some types of low-e windows block solar transmisston but also allow clear views. These treatments are not recommended for south windows.

As the table shows, skylights present a high potential for overheating, and are usually difficult to shade properly. But skylights are very popular features, and they save electricity by providing good natural daylight to the house. In some parts of the country almost every new house has at least one skylight. A good workdng compromise can usually be achleved if skylight area is limited, and if careful attention is paid to shading, exther by trees or by devices such as roller shades or blinds. The manufacturer can usually give guidance on shading options for a particular skylight design. 


\section{Shading}

Shading strategles generally fall into three categorles:

landscaping, roof overhangs and exterior or interior shading devices.

Landscaping. What the remodeler will face is a lot of exdsting greenery. Think about what you already have around your home. Existing landscaping is going to present a series of options for the owner.

Some cases will work for passtve solar and some against. The Ideal site for summer shading has deciduous trees to shade the east and west windows. Even small trees such as fruit trees can help block sun hitting the first story of a house.

Trees on the south side can present a difficult choice. Even deciduous trees will shadow the solar glazing during the winter and interfere with solar gadi. In fact, trees on the south side can all but eliminate passive solar performance, unless they are very close to the house and the low branches can be removed. allowing the winter sun to penetrate under the tree canopy. However, in many cases the trees around the house are bigger selling points than the energy efficlency and the bullder must make a choice.

If a careful study of the shading patterns is done before construction, it should be possible to accomodate the south-facing glazing while leaving in as many trees as possible (see page 17, Site Planning for Solar Access).

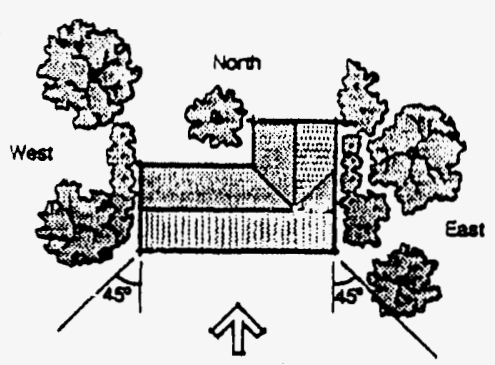

Landscaping for Summer Shado Trees and other landscaping features may be effectively used to shade east and west windows from summer solar gains.

Other landscaping ideas for summer shade:

- Trellises on east and west covered with vines.

- Shrubbery or other plantings to shade paved areas.

- Use of ground cover to prevent glare and heat absorption.

- Trees, fences, shrubbery or other plantings to "channel" summer breezes into the house. - Deciduous trees on the east and west sides of the house, as shown above, to balance solar gains in all seasons.
Roof Orerhangs. Flxed olerhangs are an inexpensive feature, and require no operation by the home owner. They must be carefully designed, however. Otherwise, an overhang that blocks summer sun may also block sun in the spring, when solar heating is desired, and, by the same token, an overhang sized for maxdmum solar gain in winter will allow solar gain in the fall on hot days. The following flgure may be used to determine the optimum overhang size.

In Baltimore, an ideal overhang projection for a four foot high window would be 23 inches and the bottom of the overhang would be 15 inches above the top of the window.

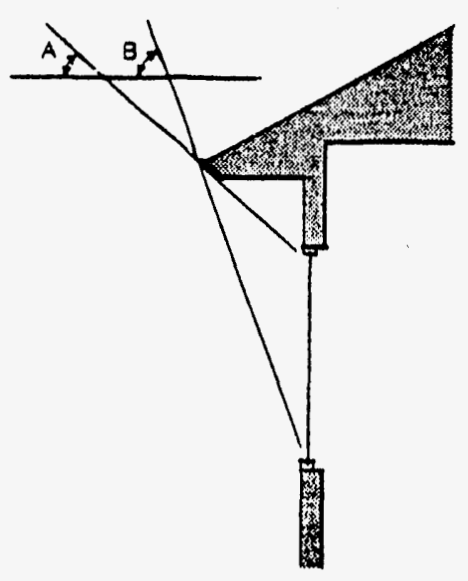

South Overhang Sizing

In Baltimore, an ideally sized south overhang should allow full exposure of the window when the sun has a noon altitude of 32

degrees (angle A) and fully shade the window when the sun has a noon altitude of 69 degrees (angle B). 
A combination of carefully sized overhangs on the south windows and shading devices on the other windows will probably be an effective solution. Adjustable overhangs that can be seasonally regulated are another option.

\section{Shading Devices. External} shades are the most effective because they stop solar gain before the sun hits the building. $A$ wide range of products are avallable, from canvas awnings to solar screens to roll-down blinds to shutters to vertical louvers. They are adjustable and perform very well, but their limitation is that they require the home owner's cooperation. Usually external screens that can be put up and taken down once a year like storm windows are more acceptable to home owners than those requiring more frequent operation.

Intertor shades must be onerated, too, and have the further disacivantage of permitting the sun to enter the house and be trapped between the w!ndow and the shading device. But highly reflective interior blinds and curtains are relatively low-cost and easy to operate.

Another shading "device" well worth considering is a porch. Especially on the east and west sides, porches add pleasant spaces to houses and are excellent for providing shade to windows. Carports located on the east or west are another option.

\section{Ceiling Fans}

Celling fans will probably save more energy than any other single cooling strategy. Studies show that air movement can make people feel comfortable at higher temperatures. As a general rule, the thermostat can be set 4 degrees higher without affecting comfort if the air is moving at 100-150 feet per minute. This is enough air movement to greatly improve comfort but not enough to disturb loose papers. In addition to circulating adr in the summer, celing fans will keep the warm air off the celling in the winter.

\begin{tabular}{|lc|}
\hline \multicolumn{2}{|c|}{ Celling Fan Sizes } \\
$\begin{array}{l}\text { Largest Room } \\
\text { Dimension }\end{array}$ & $\begin{array}{c}\text { Minimum Fan } \\
\text { Diameter } \\
\text { (inches) }\end{array}$ \\
12 feet or less & 36 \\
$12 \cdot 16$ feet & 48 \\
$16-17.5$ feet & 52 \\
$17.5-18.5$ feet & 56 \\
18.5 or more feet & 2 fans \\
\hline
\end{tabular}

A celling fan should have a minimum clearance of ten inches between celling and fan to provide adequate ventilation in a standard room with eightfoot cellings. In rooms with higher ceilings, fans should be mounted 7.5 to 8.0 feet above the floor. 


\section{Ventilation}

The prevailing wind direction is from the south during the cooling season. Windows, stairwells, transoms and other elements should be located for maxdmum cross-ventilation in each room. The free vent area (unobstructed openings like open windows) should be between $6-7.5 \%$ of total floor area, half located on the leeward and half on the windward side of the bullding. Insect screens can reduce the effective free vent area by as much as $50 \%$. Casement or awning windows have a $90 \%$ open area; double hung windows have only $50 \%$.

Natural ventilation can help keep houses cool and comfortable at the beginning and end of the cooling season and thus shorten the time when air conditioning is required. But natural ventilation can seldom do the entire cooling job. especially for less than ideal sites with little natural air movement. The effectiveness of natural ventialation is also limited by the willingness of the home owner to operate the house.

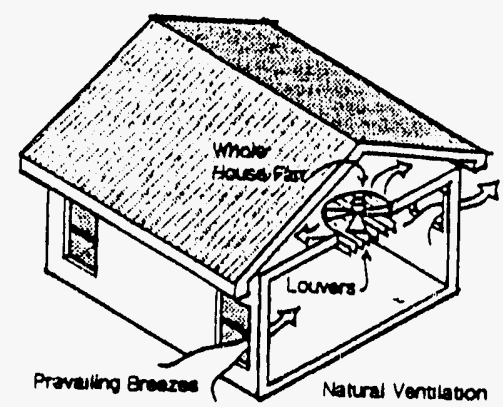

Ventllation for Summer Cooling Natural ventilation is often impaired by vegetation and topography. Ventilation fans do not depend on surroundings to be effective.

In cooling climates, a wholehouse fan is a good idea for assisting ventilation, especially in houses with sites or designs that make natural ventilation difficult. On the other hand, when the temperature is higher than about $76^{\circ} \mathrm{F}$, a whole-house fan will not be very effective.

Research indicates that a whole-house fan should pull approxdmately $10 \mathrm{ACH}$. A rule of thumb: for rooms with eight foot cellings, total floor area multiplied by 1.34 will equal the necessary CFM of the fan. For 10 foot cellings, multiply floor area by 1.67 .
The best possible performance of a whole-house fan results when a timer, a thermostat and a "humidistat" are used, so that the fan would only operate when there is less than $60 \%$ relative humidity and a temperature of less than $76^{\circ} \mathrm{F}$.

Natural ventilation and whole-house fans are effective at removing heat, but not at moving air. Celling fans, on the other hand, can often create enough of a breeze to maintain comfort at higher temperatures, and stlll use less power than required by alr conditioning. By using natural cooling strategles and low-energy fans, the days when air-conditioning is needed can be reduced substantially. 
NOTE: Please make coples of the blank worksheets and tables before entering numbers so that the worksheets may be used to evaluate several design options.

\section{Baltimore Maryland}

\section{Worksheets}


General

The Worksheets provide a calculation procedure to estiriate the performance level of passive solar bullding designs. It is recommended that the results be compared to Worksheet calculations for the bullder's typical house. Perionnaice levels for the NAHB base case used in the guidelines are aiso provided for comparison

A separate worksheet is provided for the four separate pertormance levels and assoclated base cases.

The worksheets are supported by a number of data tables. The tables are given a letter designation and are referenced next to each worksheet entry, when applicable.

The floor area used in the calculations should not include sunspaces, garages or other unconditioned spaces.

Worksheet I-Coneervation Performance Level

This is an estumate of the amount of heat energy needed by the bullding each year from both the solar system and the auxdllary heating system.

For Step A, it is necessary to measure the net area of surfaces that enclose conditioned space. For walls, the net surface area is the gross wall area less the window and door area.

Rough frame dimensions are generally used to measure window area. The R-values in Table A4 are for the rough frame window area.

Heat loss from passive solar systems is excluded. The surface area of direct gain glazing, Trombe walls, water walls and the walls that separate sunspaces from the house are ignored.

Step $A$ includes consideration of insulated foors over crawlspaces, unheated basements or garages. $R$-values are provided in Table A3 that account for the buffering effect of these unconditioned spaces. When insulation is not installed in the floor assembly, but rather around the perimeter of a crawlspace or unheated basement, Step $B$ should be used.

The permeter method of Step $B$ is used for slabs-on-grade, the below-grade portion of heated basements, unheated basements (when the floor is not insulated), and perimeter insulated crawlspaces (when the floor is not insulated). Heated basement walls that are above grade should be considered in Step A.

Slab edge perimeter, unheated basements or perimeter insulated crawlspaces adjacent to sunspaces should not be included.

The conservation performance level is calculated as the product of the heat loss per degree day per square foot (Step D) and the heating degree days, adjusted for the heat loss and solar glazing per square foot. The adjustment is taken from Table $C$, based on data calculated on Worksheet I, Step ID and Worksheet II, Step A.
Should the estimated conservation performance level be greater than desired, the designer should consider additional bullding Insulation or reducing non-south glass area.

\section{Worksheet II-Auxillary Beat}

\section{Performance Level}

This is an estimate of the amount of heat that must be provided each year from the auxdliary heating system. It accounts for savings due to solar energy.

In Step $A$, the user may enter the rough frame area of solar glazing, since it is generally easier to measure the rough frame area than it is the net glazing area. The worksheet includes a net area factor of 0.80 to account for window frames and mullions. If the designer enters the net glass area, then the net area factor is 1.00 .

The projected area of the solar systems may be calculated using the adjustment factors in Table $E$ or by making a scaled elevation drawing of the building facing exactly south and measuring the glazing area from the scaled drawing.

The projected area per square foot is calculated as the last part of Step $A$. This is used to determine the heating degree days adjustment used on Worksheet I, Step E

The load collector ratto is calculated in Step B. This is used to determine the solar savings fractions in Step $C$.

The solar systems used in Step $C$ should be identical to those used in Step $A$. The first and last columns of Step $A$ are simply carried down.

The solar savings fraction is determined separately for each type of passive solar system by looking up values in Tables FI through F4. The sunspace system types are shown beneath Table F4.

If the auxiliary heat performance level calculated in Step $D$ is larger than desired, the designer should consider increasing the size of the solar systems or adding additional solar systems, 1.e. thermal storage walls.

\section{Worksheet III-Comfort}

\section{Performance Level}

This is the temperature swing expected on a clear winter day with the auxdllary heating system not operating.

This worksheet requires that two subareas be defined within the building: those areas that receive direct solar gains and those areas that are connected to rooms that receive direct solar gains. Rooms that are separated from direct gain spaces by more than one door should not be included in either category.

Thermal mass elements located in unconditioned spaces such as sunspaces are not included.

An exposed slab is one linished with vinyl tile, ceramic tle or other highly conductive materials. Carpeted slabs should not be considered exposed. The exposed slab area should be further reduced by about 50 percent to account for throw rugs and furnishings

As a rule-of-thumb, exposed slab area should be considered to be in the sun only when it is located directly behind south glazing. The maximum slab area that is assumed to be in the sun should not exceed 1.5 times the adjacent south glass area.

In Step $F$, the projected area of solar glazing calculated on Worksheet II is used to calculate the comfort performance level. The projected area of water walls and unvented Trombe walls is excluded in this step.

A high temperature swing Indicates inadequate thermal mass or too much direct gain solar glazing. If the comfort performance level is greater than desired $\left\{13^{\circ} \mathrm{F}\right.$ recommended), additional thermal mass should be added to the bullding or direct gain glazing should be reduced.

\section{Worksheet IV-Summer Cooling} Performance Lepel

This is an estimate of the annual cooling load of the bullding-the heat that needs to be removed from the building by an air conditioner in order to maintain comfort during the summer.

In Step $A$, only the envelope surfaces that are exposed to sunllight are to be included. For Instance, lloors over crawlspaces and walls or doors adjacent to garages are excluded.

Steps $B$ and $C$ of the worksheet account for solar gains. They use the rough frame area since this is easier to measure. The worksheets include a net area factor of 0.80 to account for window frames and mullions. If the net window area is used, the net area factor is 1.00 .

Table $M$ gives the shade factor for windows with overhangs based on a. projection factor. The projection factor is the ratio between the horizontal projection of the overhang from the surface of window and the distance from the bottom of the window to the bottom of the overhang. When windows have sunscreens, tints or films, the shade factors in Table $M$ should not be used. Instead, a shading coefflcient should be determined from manufacturers literature.

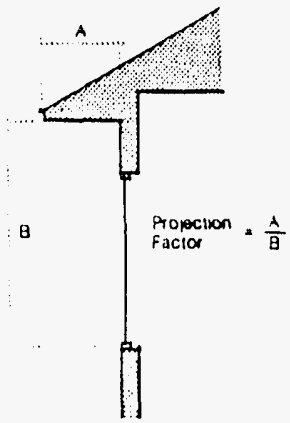

If the cooling performance level is greater than desired, the designer should consider reducing non-south glass. providing additional shading or increasing thermal mass. 
General Project Information

Project Name

Floor Area

Location

Designer

\section{Worksheet I: Conservation Performance Level}

\section{A. Envelope Heat Loss}

\begin{tabular}{|c|c|c|c|c|c|}
\hline $\begin{array}{l}\text { Construction } \\
\text { Description }\end{array}$ & Area & & $\begin{array}{c}\text { R-value } \\
\text { [Table A] }\end{array}$ & & $\begin{array}{l}\text { Heat } \\
\text { Loss } \\
\end{array}$ \\
\hline \multirow[t]{2}{*}{ Ceilings/roots } & & $\div$ & & $=$ & \\
\hline & & 7 & & - & \\
\hline \multirow{2}{*}{ Walls } & & + & & $=$ & \\
\hline & & $\div$ & & $=$ & \\
\hline \multirow[t]{2}{*}{ Insulated Floors } & & + & & $=$ & \\
\hline & & + & & $=$ & \\
\hline \multirow[t]{2}{*}{ Non-solar Glazing } & & + & & $=$ & \\
\hline & & + & & $=$ & \\
\hline \multirow[t]{2}{*}{ Doors } & & $\div$ & & $=$ & \\
\hline & & $\div$ & & $=$ & \\
\hline
\end{tabular}

\section{B. Foundation Perimeter Heat Loss}

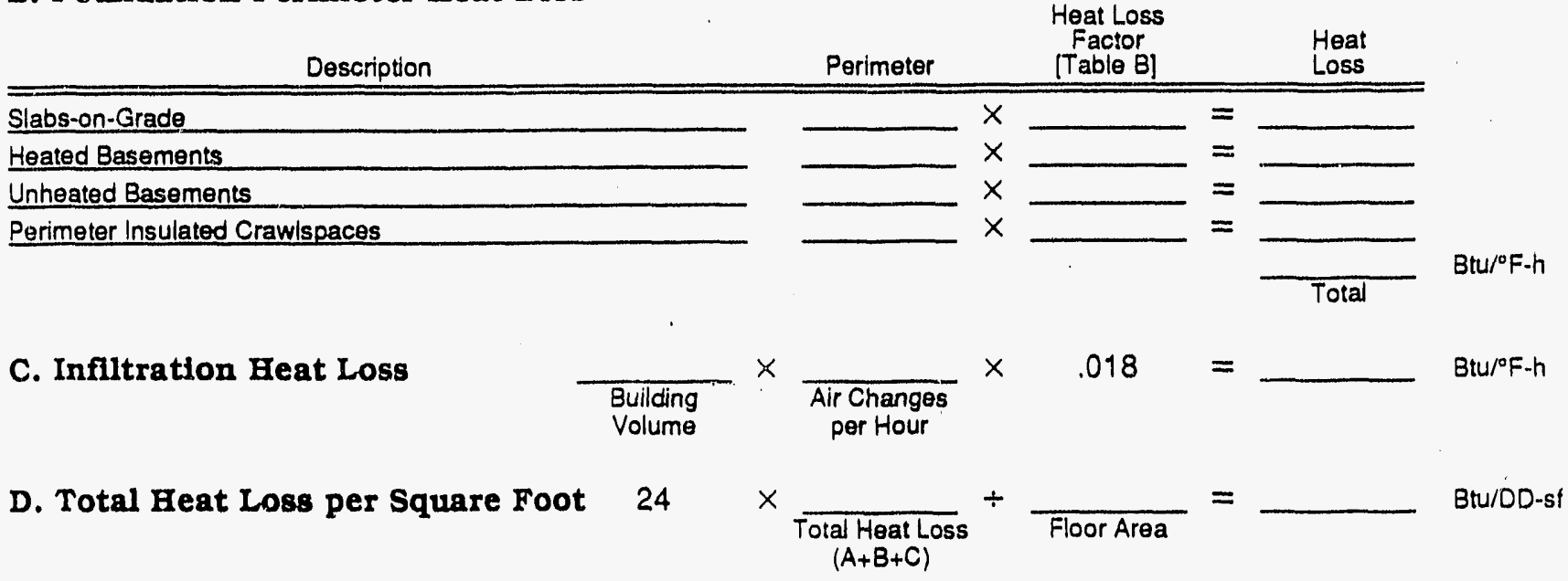

E. Conservation Performance Level

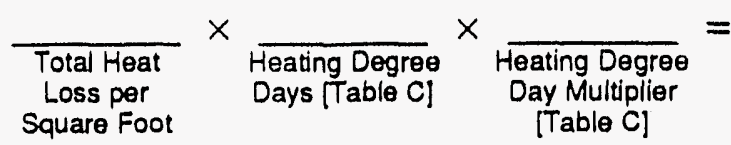

$=-B$ Btu/yr-sf

Square Foot

F. Comparison Conservation Performance (From Previous Calculation or from Table D)

Btu/yr-st 


\section{A. Projected Area of Passive Solar Glazing}

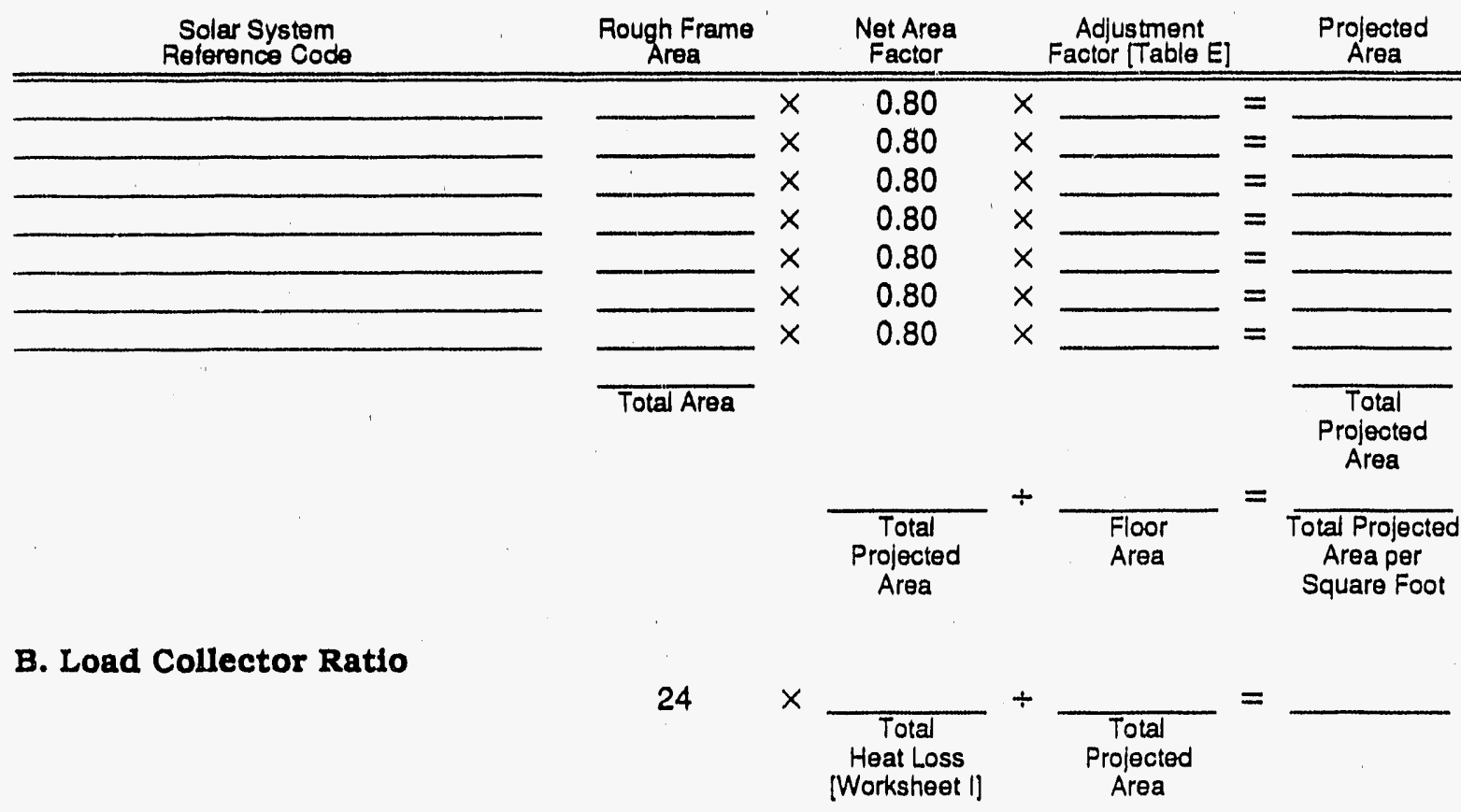

\section{Solar Savings Fraction}

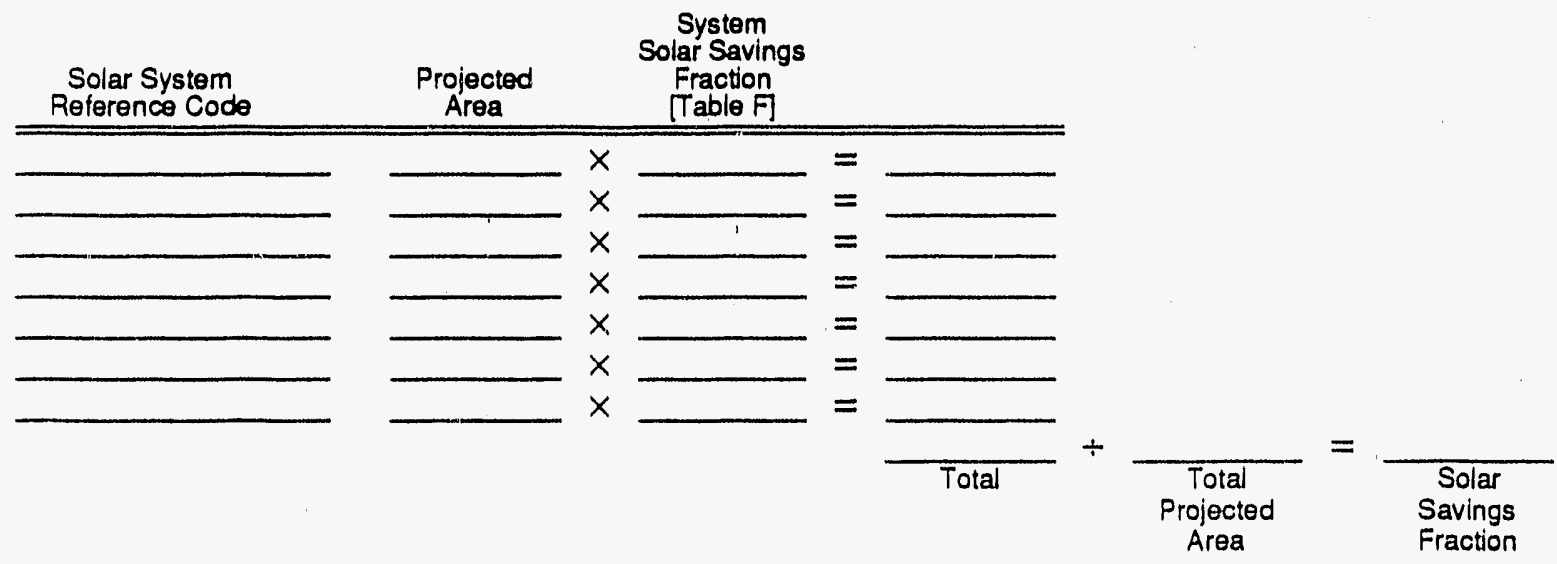

D. Auxillary Heat Performance Level

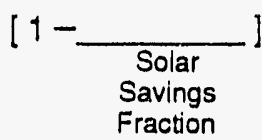

Fraction ] $x$ Conservation
Performance Performance
Level [Worksheet I Step E]
$=$

Btu/yr-sf

Btu/yr-sf

E. Comparative Aurdliary Heat Performance (From Previous Calculation or from Table G) 
A. Heat Capacity of Sheetrock and Interior Furnishings

\begin{tabular}{|c|c|c|c|c|c|}
\hline & Floor Area & & $\begin{array}{c}\text { Unit } \\
\text { Heat } \\
\text { Capacity } \\
\end{array}$ & & $\begin{array}{c}\text { Total } \\
\text { Heat } \\
\text { Capacity } \\
\end{array}$ \\
\hline Rooms with Diroct Gain & 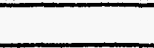 & $x$ & 4.7 & $=$ & \\
\hline Spaces Connected to Dlrect Gain Spaces & 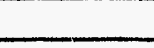 & $x$ & 4.5 & $=$ & \\
\hline
\end{tabular}

\section{B. Heat Capacity of Mas : Surfaces Enclosing Direct Gain Spaces}

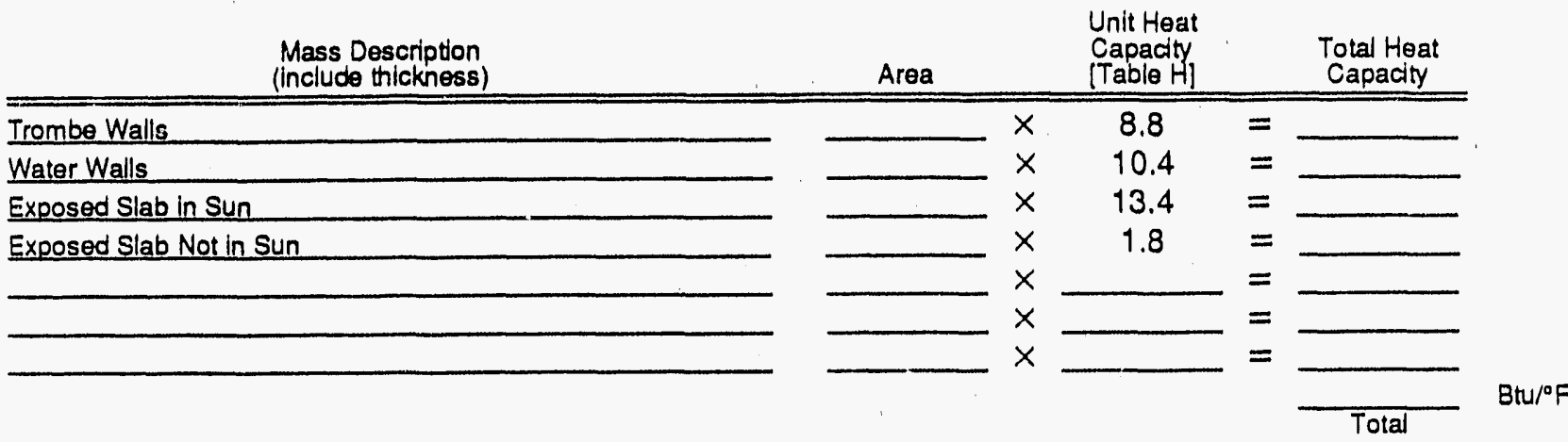

C. Heat Capacity of Mass Surfaces Enclosing Spaces Connected to Direct Gain Spaces

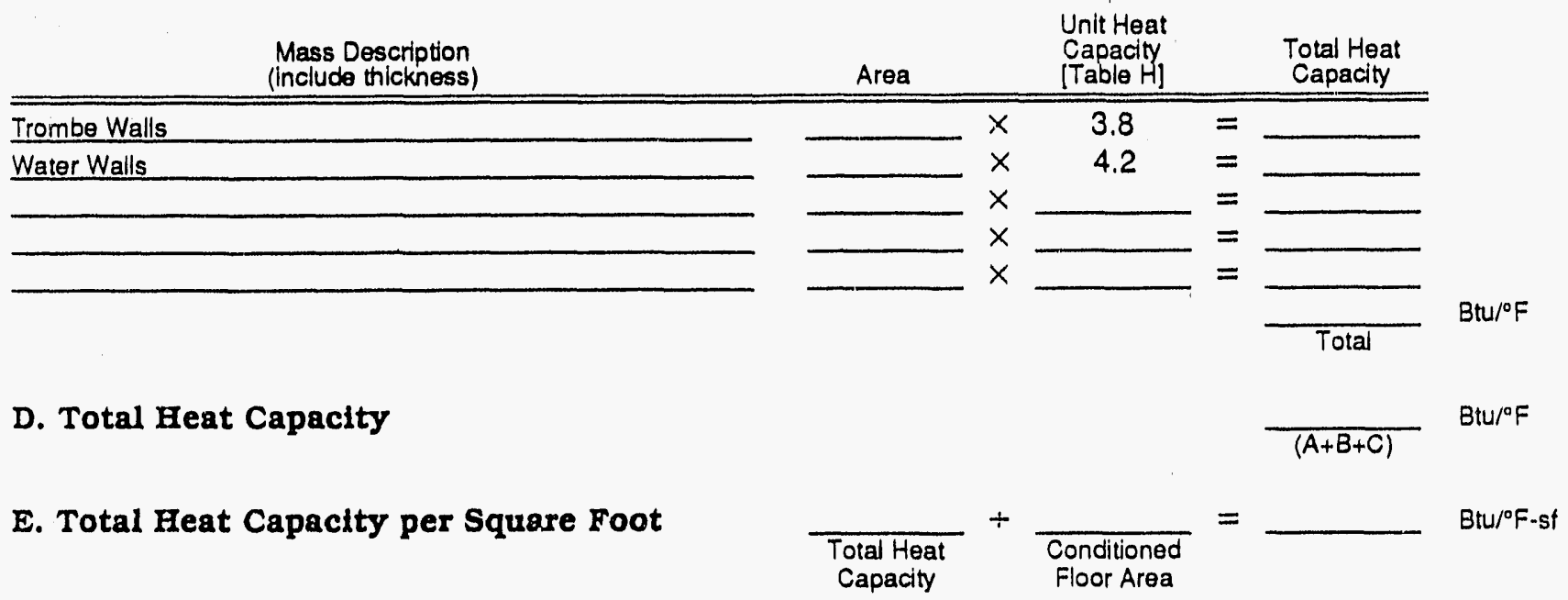

F. Clear Winter Day Temperature Swing

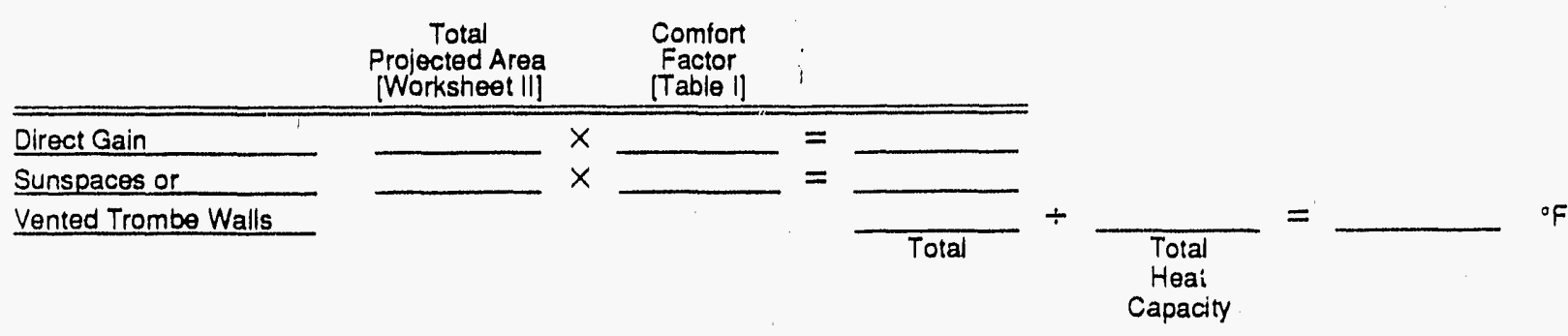

G. Recommended Maximum Temperature Swing 


\section{A. Opaque Surfaces}

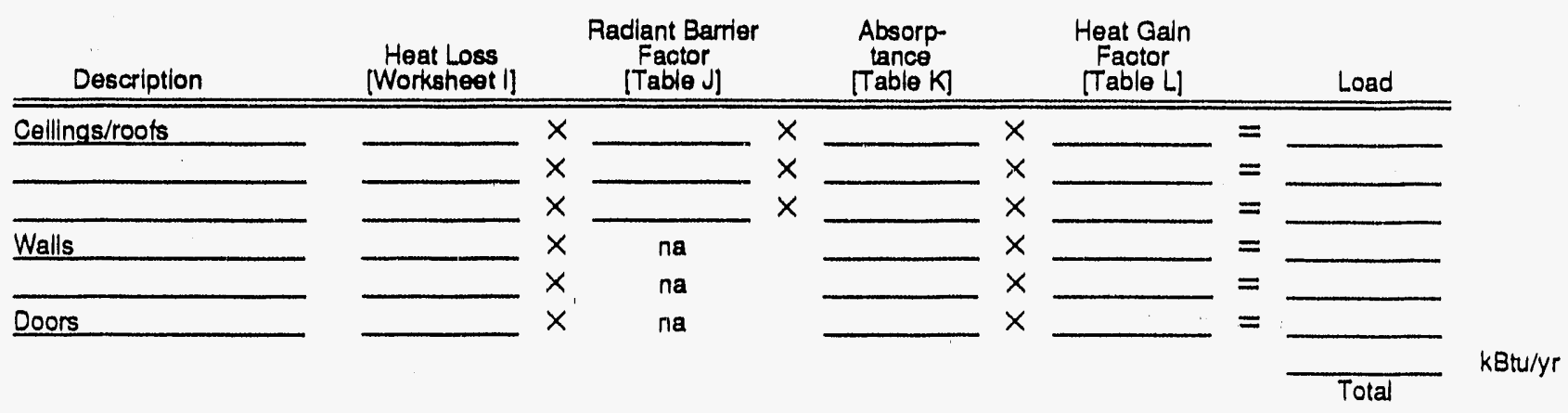

\section{B. Non-solar Glazing}

\begin{tabular}{|c|c|c|c|c|c|c|c|c|c|}
\hline Description & $\begin{array}{c}\text { Rough Frame } \\
\text { Area }\end{array}$ & & $\begin{array}{c}\text { Net Area } \\
\text { Factor }\end{array}$ & & $\begin{array}{c}\text { Shade Factor } \\
\text { [Table M] }\end{array}$ & & $\begin{array}{l}\text { Heat Gain } \\
\text { Factor [Table L] }\end{array}$ & & Load \\
\hline North Glass & & $x$ & 0.80 & $x$ & & $x$ & & $=$ & \\
\hline East Glass & & $x$ & 0.80 & $x$ & & $x$ & & $=$ & \\
\hline West Glass & & $x$ & 0.80 & $x$ & & $x$ & & $=$ & \\
\hline Skylights & & $x$ & 0.80 & $x$ & & $x$ & & $=$ & \\
\hline
\end{tabular}

\section{Solar Glazing}

Solar System

Description

Direct Gain

Storage Walls

Sunspace

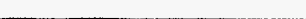

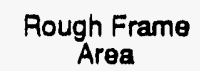

\begin{tabular}{cc}
$\begin{array}{c}\text { Net Area } \\
\text { Factor }\end{array}$ & $\begin{array}{c}\text { Shade Factor } \\
\text { [Table M] }\end{array}$ \\
\hline 0.80 & $\times$ \\
0.80 & $\times$ \\
0.80 & $\times$ \\
0.80 & $\times$
\end{tabular}

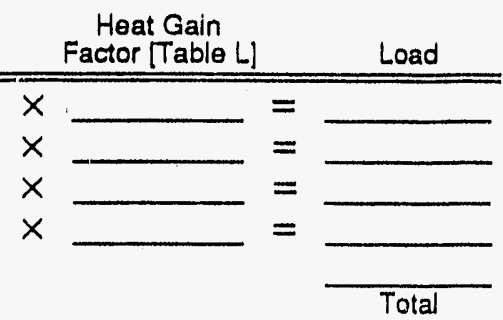

kBtu/yr

D. Internal Gain

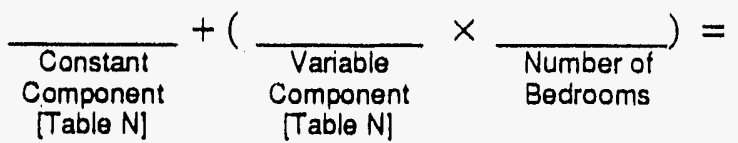

kBtu/yr

E. Cooling Load per Square Foot

1,000

$$
\times \frac{}{(A+B+C+D)}
$$

$\div \frac{}{\text { Floor Area }}=$

Btu/yr-sf

F. Adjustment for Thermal Mass and Ventilation

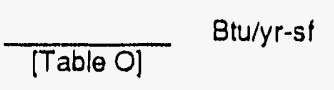

G. Cooling Performance Level

H. Comparison Cooling Performance (From Previous Calaulation or from Table P) 


\begin{tabular}{|c|c|c|c|c|}
\hline \multicolumn{5}{|c|}{$\begin{array}{l}\text { Table A-Equiralent Thermal } \\
\text { Performance of Ansemblles } \\
\text { R-values (br-F-af/Btu) }\end{array}$} \\
\hline \multicolumn{5}{|c|}{ A1-Collinge/Poole } \\
\hline \multirow[t]{2}{*}{$\begin{array}{l}\text { Attic Truss } \\
\text { Construction }\end{array}$} & R.19 & $\begin{array}{c}\text { Insulatio } \\
\mathrm{R}=30\end{array}$ & $\begin{array}{c}\text { R.value } \\
R-49\end{array}$ & $R-60$ \\
\hline & 17.4 & 27.9 & 46.9 & 57.9 \\
\hline $\begin{array}{l}\text { Framed Rafter } \\
\text { Constuction }\end{array}$ & $R \cdot 11$ & $\begin{array}{c}\text { Insulatio } \\
\mathrm{R}-19\end{array}$ & $\begin{array}{c}\text { R.value } \\
\text { R.30 }\end{array}$ & R.38 \\
\hline $\begin{array}{l}2 \times 6 \text { at } 16^{\circ} \circ 0 \\
2 \times 6 \text { at } 24^{\prime \prime} \circ c \\
2 \times 8 \text { at } 16^{\circ} \circ c \\
2 \times 8 \text { at } 24^{\circ} \circ 0 \\
2 \times 10 \text { at } 16^{\circ} \infty \\
2 \times 10 \text { at } 24^{\circ} \infty \\
2 \times 12 \text { at } 16^{\circ} \infty \\
2 \times 12 \text { at } 24^{\circ} \infty\end{array}$ & $\begin{array}{l}10.2 \\
10.4 \\
10.7 \\
10.8 \\
11.2 \\
11.2 \\
11.7 \\
11.5\end{array}$ & $\begin{array}{l}14.7 \\
15.3 \\
17.0 \\
17.6 \\
18.1 \\
18.4 \\
18.8 \\
19.0\end{array}$ & $\begin{array}{l}16.3 \\
17.1 \\
20.6 \\
21.6 \\
24.5 \\
25.5 \\
25.5 \\
27.3\end{array}$ & $\begin{array}{l}\overline{-} \\
21.1 \\
22.2 \\
25.7 \\
26.8 \\
30.1 \\
31.4\end{array}$ \\
\hline
\end{tabular}

\section{A2-Framod Walto}

\begin{tabular}{|c|c|c|c|c|}
\hline $\begin{array}{l}\text { Single } \\
\text { Wall } \\
\text { Framing }\end{array}$ & 8.7 & $\begin{array}{c}\text { Insulatio } \\
\text { R-11 }\end{array}$ & $\begin{array}{c}\text { R-value } \\
\text { R.19 }\end{array}$ & \\
\hline $\begin{array}{l}2 \times 4 \text { al } 16^{\circ} \circ \mathrm{Oc} \\
2 \times 4 \text { al } 24^{\circ \circ} \mathrm{Oc} \\
2 \times 6 \text { al } 16^{\circ} \mathrm{OC} \\
2 \times 6 \text { al } 24^{\circ} \mathrm{OC}\end{array}$ & $\begin{array}{l}6.5 \\
6.6 \\
7.0 \\
7.0\end{array}$ & $\begin{array}{l}12.0 \\
12.7 \\
14.1 \\
14.3\end{array}$ & $\frac{\overline{-}}{17.7}$ & \\
\hline $\begin{array}{l}\text { Double } \\
\text { Wall } \\
\text { Framing }\end{array}$ & \multicolumn{4}{|c|}{ Total Thickness (inches) } \\
\hline & 25.0 & 31.3 & 37.5 & \\
\hline
\end{tabular}

The R.value of insulating sheathing should be added to the values in this table.

\begin{tabular}{|c|c|c|c|c|}
\hline \multicolumn{5}{|c|}{ A3-Insulated Floors } \\
\hline Framing & \multicolumn{4}{|c|}{ Insulation R-value } \\
\hline $\begin{array}{l}2 \times 65 \text { at } 16^{\circ} \propto c \\
2 \times 6 s \text { at } 24^{*} \propto \\
2 \times 8 s \text { at } 16^{*} \propto \\
2 \times 8 s \text { at } 24^{*} \propto c \\
2 \times 10 \text { at } 16^{*} \propto c \\
2 \times 10 \text { at } 24^{\circ} \propto c \\
2 \times 12 \text { at } 16^{*} \propto c \\
2 \times 12 \text { at } 24^{*} \propto\end{array}$ & $\begin{array}{l}18.2 \\
18.4 \\
18.8 \\
18.9 \\
19.3 \\
19.3 \\
19.7 \\
19.6\end{array}$ & $\begin{array}{l}23.8 \\
24.5 \\
24.9 \\
25.4 \\
25.8 \\
26.1 \\
26.5 \\
26.7\end{array}$ & $\begin{array}{l}29 . \\
31 . \\
31 . \\
33 . \\
33 . \\
34 . \\
34 . \\
35 .\end{array}$ & $\begin{array}{ll}.9 & - \\
.5 & - \\
.7 & 36.0 \\
.4 & 37.9 \\
.4 & 39.1 \\
.7 & 39.8 \\
.5 & 41.2\end{array}$ \\
\hline \multicolumn{5}{|c|}{$\begin{array}{l}\text { These R.values indude the buffering effect of a } \\
\text { venulated crawlspace or unconditioned basement. }\end{array}$} \\
\hline \multicolumn{5}{|c|}{ 44-Windowe } \\
\hline & $\begin{array}{l}\text { Wooc } \\
\text { Fram }\end{array}$ & & & $\begin{array}{l}\text { Metal } \\
\text { Framew/ } \\
\text { Thermal } \\
\text { Break }\end{array}$ \\
\hline $\begin{array}{l}\text { Double } \\
1 / 4^{*} \text { space } \\
1 / 2 \text { space } \\
\text { Low.e }\end{array}$ & $\begin{array}{l}1.8 \\
2.1 \\
3.1\end{array}$ & & & $\begin{array}{l}1.5 \\
1.8 \\
3.0\end{array}$ \\
\hline $\begin{array}{l}\text { Triple } \\
1 / 4^{*} \text { space } \\
1 / 2^{*} \text { space }\end{array}$ & $\begin{array}{l}2.7 \\
3.3\end{array}$ & & & $\begin{array}{l}2.1 \\
27\end{array}$ \\
\hline \multicolumn{5}{|c|}{$\begin{array}{l}\text { These R.values are for the enure rough lrame window } \\
\text { opening. When storm sash is added, an additional } 1.1 \\
\text { may be added. One hall the R-value of moveable } \\
\text { insulaton may also be added, when appropnate. }\end{array}$} \\
\hline
\end{tabular}

Table A-oontinued ..

\begin{tabular}{lc}
\multicolumn{1}{c}{ A5-Door } \\
\hline $\begin{array}{l}\text { Solld wood with } \\
\text { Weatherstripping }\end{array}$ & 2.2 \\
Motal with rigid & 5.9 \\
loam core & \\
\hline
\end{tabular}

Table B-Perimeter Beat Lose

Fantors for Slabe-on-Grade and Unheated Basement: (Btu/b-F-ft)

\begin{tabular}{|c|c|c|c|c|}
\hline Im & $\begin{array}{l}\text { Slabs-on. } \\
\text { Grado }\end{array}$ & $\begin{array}{l}\text { Heated } \\
\text { Base- } \\
\text { ments }\end{array}$ & $\begin{array}{l}\text { Unheated } \\
\text { Baso } \\
\text { men's }\end{array}$ & $\begin{array}{l}\text { Insulated } \\
\text { Craw|- } \\
\text { spaces }\end{array}$ \\
\hline & $\begin{array}{l}0.8 \\
0.4 \\
0.3 \\
0.3 \\
0.2 \\
0.1\end{array}$ & $\begin{array}{l}1.3 \\
0.8 \\
0.7 \\
0.6 \\
0.4 \\
0.3\end{array}$ & $\begin{array}{l}1.1 \\
0.7 \\
0.6 \\
0.5 \\
0.5 \\
0.4\end{array}$ & $\begin{array}{l}1.1 \\
0.6 \\
0.5 \\
0.4 \\
0.3 \\
0.2\end{array}$ \\
\hline
\end{tabular}

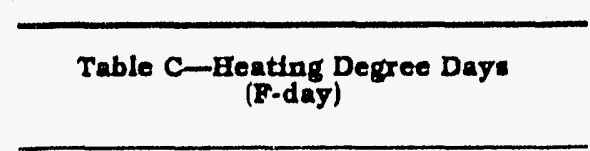

\begin{tabular}{c}
\hline Cy-Heating Dogreo Days (Base 65० $\mathrm{F}$ ) \\
Baltimore \\
4,706 \\
\hline
\end{tabular}

\begin{tabular}{|c|c|c|c|c|c|}
\hline \multicolumn{6}{|c|}{ C2-Hosting Dogreo Day Munupiier } \\
\hline Heat Loss & 9 & $\begin{array}{c}P \\
\text { Gla }\end{array}$ & $\begin{array}{l}\text { sive So } \\
\text { ing Aves }\end{array}$ & & \\
\hline $\begin{array}{l}12.00 \\
11.50 \\
11.00 \\
1.50 \\
10.00 \\
9.50 \\
9.00 \\
8.50 \\
8.00 \\
7.50 \\
7.00 \\
6.50 \\
6.00 \\
5.50 \\
5.00 \\
4.50 \\
4.00 \\
3.50 \\
3.00 \\
2.50 \\
2.00\end{array}$ & $\begin{array}{l}1.10 \\
1.10 \\
1.09 \\
1.68 \\
1.07 \\
1.06 \\
1.05 \\
1.04 \\
1.03 \\
1.01 \\
0.99 \\
0.97 \\
0.95 \\
0.93 \\
0.90 \\
0.86 \\
0.82 \\
0.77 \\
0.70 \\
0.60 \\
0.47\end{array}$ & $\begin{array}{l}1.11 \\
1.10 \\
1.10 \\
1.09 \\
1.08 \\
1.07 \\
1.07 \\
1.05 \\
1.04 \\
1.03 \\
1.01 \\
1.00 \\
0.98 \\
0.96 \\
0.93 \\
0.91 \\
0.87 \\
0.83 \\
0.78 \\
0.71 \\
0.61\end{array}$ & $\begin{array}{l}1.12 \\
1.11 \\
1.11 \\
1.10 \\
1.09 \\
1.09 \\
1.08 \\
1.07 \\
1.06 \\
1.05 \\
1.03 \\
1.02 \\
1.00 \\
0.98 \\
0.96 \\
0.94 \\
0.91 \\
0.88 \\
0.84 \\
0.79 \\
0.73\end{array}$ & $\begin{array}{l}1.12 \\
1.12 \\
1.11 \\
1.11 \\
1.10 \\
1.09 \\
1.09 \\
1.08 \\
1.07 \\
1.06 \\
1.05 \\
1.04 \\
1.02 \\
1.00 \\
0.98 \\
0.96 \\
0.94 \\
0.92 \\
0.89 \\
0.85 \\
0.80\end{array}$ & $\begin{array}{l}1.13 \\
1.12 \\
1.12 \\
1.11 \\
1.11 \\
1.10 \\
1.10 \\
1.09 \\
1.08 \\
1.07 \\
1.06 \\
1.05 \\
1.04 \\
1.02 \\
1.01 \\
0.99 \\
0.97 \\
0.95 \\
0.92 \\
0.89 \\
0.86\end{array}$ \\
\hline
\end{tabular}

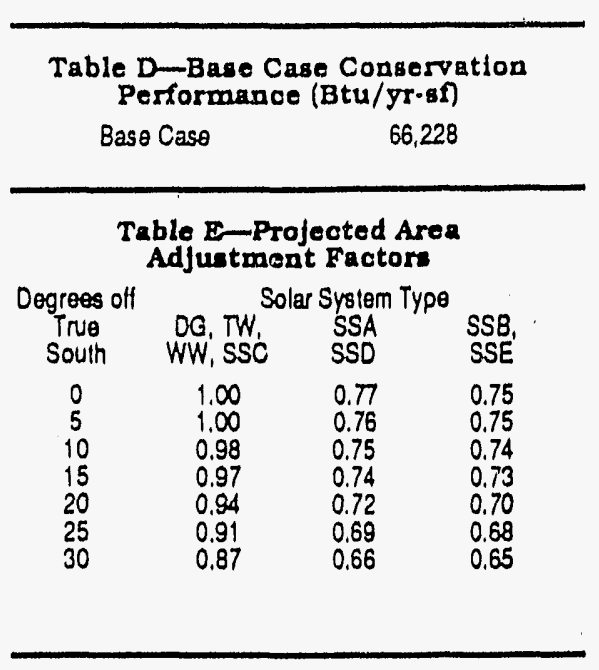

Table F-Solar System Saving Fractione

\begin{tabular}{cccc}
\multicolumn{5}{c}{$\begin{array}{c}\text { F1-Direct Gain } \\
\text { Load } \\
\text { Collector } \\
\text { Ratio }\end{array}$} & $\begin{array}{c}\text { DGC1 } \\
\text { Double } \\
\text { Glazing }\end{array}$ & $\begin{array}{c}\text { Low- } \\
\text { Glazing }\end{array}$ & $\begin{array}{c}\text { OGC3 } \\
\text { R.9 Night } \\
\text { Insulation }\end{array}$ \\
400 & 0.04 & 0.04 & 0.05 \\
300 & 0.04 & 0.05 & 0.07 \\
200 & 0.06 & 0.08 & 0.10 \\
150 & 0.08 & 0.10 & 0.12 \\
100 & 0.11 & 0.14 & 0.18 \\
80 & 0.13 & 0.17 & 0.21 \\
60 & 0.17 & 0.21 & 0.27 \\
50 & 0.19 & 0.25 & 0.32 \\
45 & 0.20 & 0.27 & 0.35 \\
40 & 0.22 & 0.29 & 0.38 \\
35 & 0.24 & 0.33 & 0.42 \\
30 & 0.27 & 0.36 & 0.47 \\
25 & 0.30 & 0.41 & 0.54 \\
20 & 0.34 & 0.48 & 0.61 \\
15 & 0.39 & 0.56 & 0.72 \\
& & & \\
\hline
\end{tabular}

\begin{tabular}{|c|c|c|c|c|}
\hline \multicolumn{5}{|c|}{ F2-Trombe Walls } \\
\hline $\begin{array}{l}\text { Load } \\
\text { Collector } \\
\text { Ratio }\end{array}$ & $\begin{array}{l}\text { TWF3 } \\
\text { Unvented } \\
\text { Non- } \\
\text { selective }\end{array}$ & $\begin{array}{c}\text { TWA3 } \\
\text { Vented } \\
\text { Non- } \\
\text { Selective }\end{array}$ & $\begin{array}{l}\text { TWJJ2 } \\
\text { Unvented } \\
\text { Selec- } \\
\text { tive }\end{array}$ & $\begin{array}{l}\text { TWL } \\
\text { Unvented } \\
\text { Night } \\
\text { Insulation }\end{array}$ \\
\hline $\begin{array}{l}400 \\
300 \\
200 \\
150 \\
100 \\
80 \\
60 \\
50 \\
45 \\
40 \\
35 \\
30 \\
25 \\
20 \\
15\end{array}$ & $\begin{array}{l}0.02 \\
0.03 \\
0.05 \\
0.07 \\
0.10 \\
0.13 \\
0.16 \\
0.19 \\
0.21 \\
0.23 \\
0.25 \\
0.28 \\
0.32 \\
0.37 \\
0.44\end{array}$ & $\begin{array}{l}0.05 \\
0.06 \\
0.08 \\
0.10 \\
0.13 \\
0.16 \\
0.20 \\
0.22 \\
0.24 \\
0.26 \\
0.29 \\
0.32 \\
0.36 \\
0.41 \\
0.48\end{array}$ & $\begin{array}{l}0.02 \\
0.04 \\
0.08 \\
0.12 \\
0.19 \\
0.24 \\
0.30 \\
0.35 \\
0.38 \\
0.42 \\
0.46 \\
0.51 \\
0.57 \\
0.64 \\
0.73\end{array}$ & $\begin{array}{l}0.60 \\
0.01 \\
0.05 \\
0.08 \\
0.14 \\
0.18 \\
0.24 \\
0.29 \\
0.31 \\
0.25 \\
0.39 \\
0.43 \\
0.49 \\
0.56 \\
0.66\end{array}$ \\
\hline
\end{tabular}




\section{Passive Solar Design Strategies}

\begin{tabular}{cccc}
\hline \multicolumn{4}{c}{ F3-Water Walls } \\
$\begin{array}{c}\text { Load } \\
\text { WWA3 } \\
\text { Collector } \\
\text { Ratio }\end{array}$ & $\begin{array}{c}\text { No Night } \\
\text { Insulation }\end{array}$ & $\begin{array}{c}\text { Nlght } \\
\text { Insulation }\end{array}$ & $\begin{array}{c}\text { WWC2 } \\
\text { Selective } \\
\text { Surface }\end{array}$ \\
400 & 0.03 & 0.00 & 0.00 \\
300 & 0.05 & 0.01 & 0.02 \\
200 & 0.07 & 0.06 & 0.07 \\
150 & 0.10 & 0.10 & 0.11 \\
100 & 0.14 & 0.18 & 0.18 \\
80 & 0.17 & 0.23 & 0.22 \\
60 & 0.21 & 0.30 & 0.30 \\
50 & 0.25 & 0.36 & 0.34 \\
45 & 0.27 & 0.39 & 0.38 \\
40 & 0.29 & 0.42 & 0.41 \\
35 & 0.32 & 0.47 & 0.45 \\
30 & 0.35 & 0.52 & 0.50 \\
25 & 0.39 & 0.58 & 0.56 \\
20 & 0.45 & 0.66 & 0.64 \\
15 & 0.53 & 0.75 & 0.73 \\
& & &
\end{tabular}

\begin{tabular}{|c|c|c|c|c|c|}
\hline & & $\mathrm{F} 4$ & 2800 & & \\
\hline $\begin{array}{l}\text { Load } \\
\text { Collecto } \\
\text { Ratio }\end{array}$ & SSA1 & SSB1 & $\begin{array}{l}\text { nspace } \\
\text { SSC1 }\end{array}$ & $\begin{array}{l}\text { Ype } \\
\text { SSD1 }\end{array}$ & SSE1 \\
\hline $\begin{array}{l}400 \\
300 \\
200 \\
150 \\
100 \\
80 \\
60 \\
50 \\
45 \\
40 \\
35 \\
30 \\
25 \\
20 \\
15\end{array}$ & $\begin{array}{l}0.09 \\
0.11 \\
0.13 \\
0.15 \\
0.19 \\
0.22 \\
0.26 \\
0.29 \\
0.31 \\
0.33 \\
0.35 \\
0.38 \\
0.42 \\
0.47 \\
0.53\end{array}$ & $\begin{array}{l}0.07 \\
0.09 \\
0.11 \\
0.12 \\
0.16 \\
0.18 \\
0.22 \\
0.24 \\
0.26 \\
0.28 \\
0.30 \\
0.33 \\
0.36 \\
0.41 \\
0.47\end{array}$ & $\begin{array}{l}0.03 \\
0.05 \\
0.07 \\
0.09 \\
0.12 \\
0.15 \\
0.18 \\
0.21 \\
0.23 \\
0.25 \\
0.27 \\
0.30 \\
0.34 \\
0.39 \\
0.46\end{array}$ & $\begin{array}{l}0.08 \\
0.10 \\
0.13 \\
0.16 \\
0.21 \\
0.25 \\
0.30 \\
0.34 \\
0.36 \\
0.38 \\
0.41 \\
0.45 \\
0.49 \\
0.55 \\
0.62\end{array}$ & $\begin{array}{l}0.06 \\
0.08 \\
0.10 \\
0.13 \\
0.17 \\
0.20 \\
0.25 \\
0.28 \\
0.30 \\
0.32 \\
0.35 \\
0.38 \\
0.42 \\
0.47 \\
0.53\end{array}$ \\
\hline
\end{tabular}

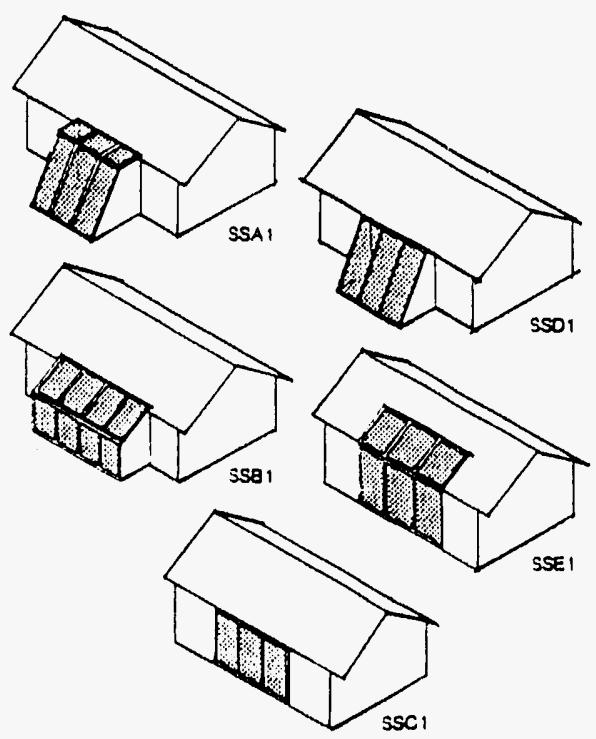

Table G-Base Case Aurdllary Beat Performance (Btu/yr-at)

Base Case 64,020

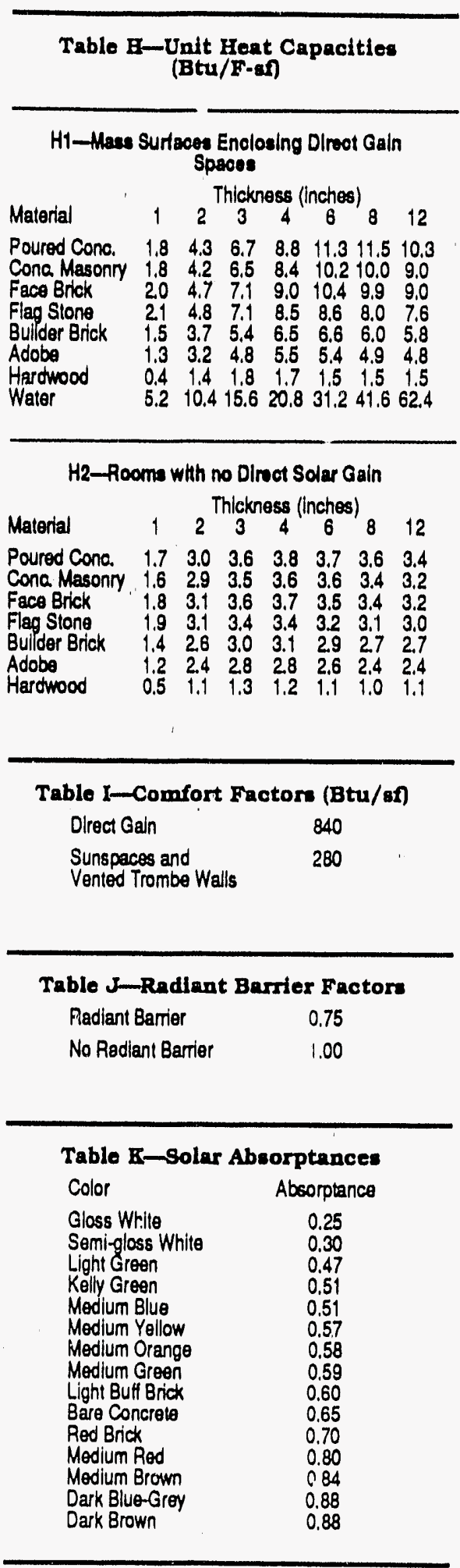

Table I-Heat Gain Factors

$\begin{array}{lc}\text { Celling/roois } & 45.7 \\ \text { Walls and Doors } & 23.2 \\ \text { North Glass } & 34.5 \\ \text { East Glass } & 63.2 \\ \text { West Glass } & 67.8 \\ \text { Skyllghts } & 123.6 \\ \text { Direct Gain Glazing } & 55.5 \\ \text { Trombe Walls and } & 11.2 \\ \text { Water Walls } & \\ \text { Sunspaces } & \\ \text { SSA1 } & 33.0 \\ \text { SSB1 } & 33.0 \\ \text { SSC1 } & 11.2 \\ \text { SSD1 } & 33.0 \\ \text { SSE1 } & 33.0\end{array}$

\begin{tabular}{|c|c|c|c|c|}
\hline \multicolumn{5}{|c|}{ Table M-Shadlng Factors } \\
\hline $\begin{array}{l}\text { Projection } \\
\text { Factor }\end{array}$ & South & East & North & $W_{e}$ \\
\hline $\begin{array}{l}0.00 \\
0.20 \\
0.40 \\
0.60 \\
0.80 \\
1.00 \\
1.20\end{array}$ & $\begin{array}{l}1.00 \\
0.86 \\
0.66 \\
0.50 \\
0.34 \\
0.29 \\
0.24\end{array}$ & $\begin{array}{l}1.00 \\
0.94 \\
0.83 \\
0.71 \\
0.60 \\
0.50 \\
0.40\end{array}$ & $\begin{array}{l}1.00 \\
0.92 \\
0.83 \\
0.75 \\
0.66 \\
0.57 \\
0.49\end{array}$ & $\begin{array}{l}1 . \\
0 . \\
0 .\end{array}$ \\
\hline
\end{tabular}

Table N-Internal Gain Factors Constant Component 2,040 kBtu/yr Variable Component $850 \mathrm{kBtu} / \mathrm{yr} \cdot \mathrm{BR}$

Table O-Thermal Mass and

Ventilation Adjustment (Btu/yr-sf)

Total Heat Night Night No Night No Night Capacity Ventw/ Ventw/No Ventw/ Vent w/No per SF Ceil. Fan Coil. Fan Ceil. Fan Cail. Fan

$\begin{array}{rrrrc}0.0 & 3,480 & 1,010 & 1,820 & .1,190 \\ 1.0 & 4,780 & 2,400 & 3,110 & 190 \\ 2.0 & 5,410 & 3,130 & 3,750 & 930 \\ 3.0 & 5,710 & 3,530 & 4,050 & 1,320 \\ 4.0 & 5,860 & 3,740 & 4,200 & 1,530 \\ 5.0 & 5,940 & 3,850 & 4,280 & 1,640 \\ 6.0 & 5,970 & 3,910 & 4,310 & 1,700 \\ 7.0 & 5,990 & 3,940 & 4,330 & 1,730 \\ 8.0 & 6,000 & 3,960 & 4,340 & 1,750 \\ 9.0 & 6,000 & 3,970 & 4,340 & 1,760 \\ 10.0 & 6,010 & 3,970 & 4,340 & 1,770\end{array}$

Total heat capacity per square toot is calculated on Worksheet III, Slep E

Table P-Base Case Cooling Performance (Btu/sf-yr) Base Case 12,081 


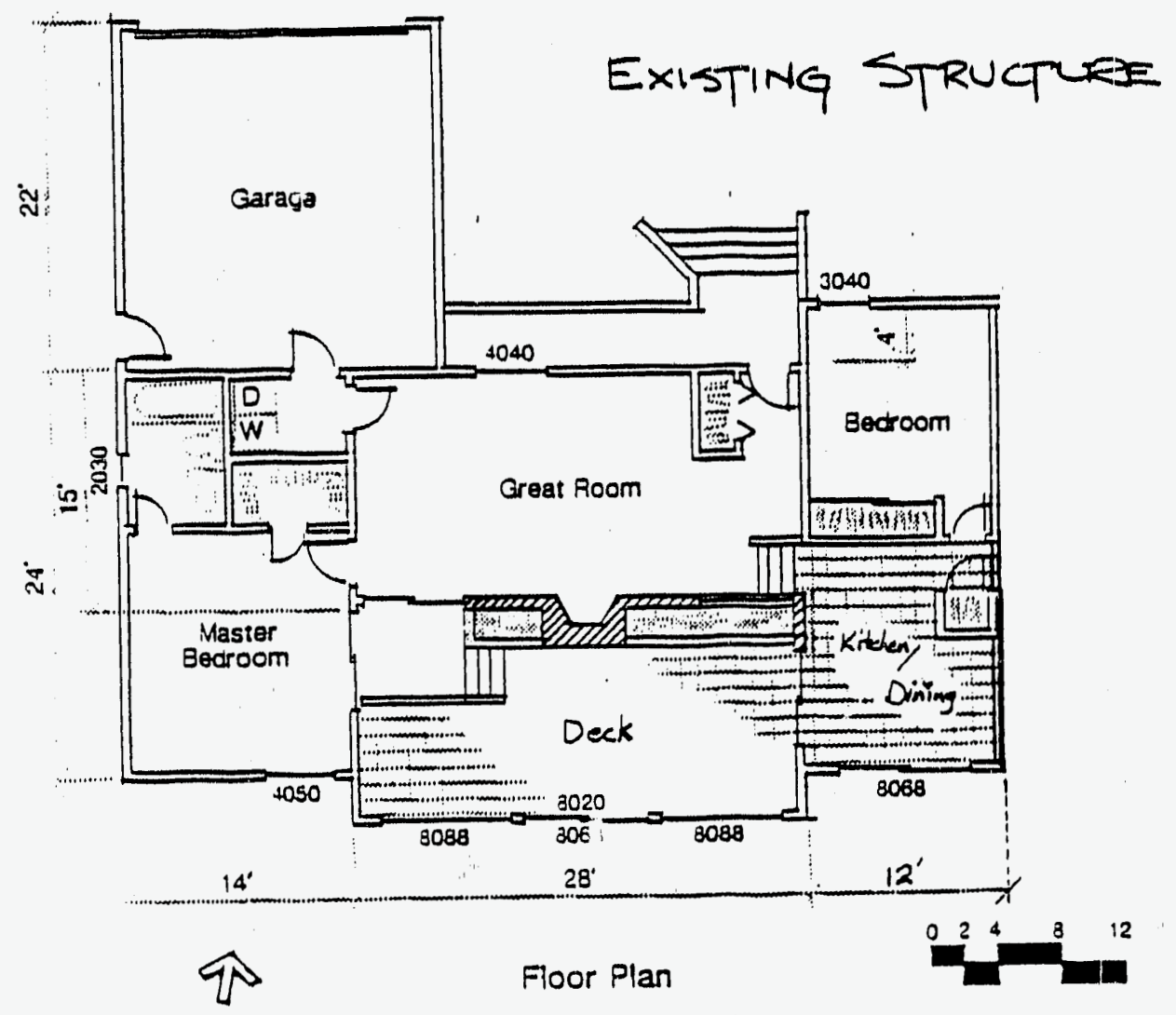

\section{Baltimore Maryland}

\section{The Worked Example}




\section{The Worked Example}

\section{Description of \\ Erample Building}

A 1,116 square foot single family home is used to lllustrate how to fill in the worksheets. A 696 square foot remodel including the addition of glazing and mass in the dining room/kdtchen and conversion of a south patio area into a semi-enclosed sunspace is used as an example. See sketches for the bullding layout. A varlety of design features have been incorporated into the house to help illustrate how to handle different situations in the worksheets.

The bullding selected has typical insulation for an exdsting home. The remodel involves: (1) increasing the celling insulation of the entre structure, (2) much improved insulation values for the walls and perimeter of the addition only, and (3) reducing the infiltration level of the entire house from $0.75 \mathrm{ACH}$ to 0.5
The east portion of the house is slab on grade. The great room and master bedroom are constructed over a basement.

The remodel includes a semenclosed sunspace with vertical glazing. The sunspace floor has a four-Inch thick slab-on-grade with quarry tile set in a mortar bed. The sunspace is separated from the conditioned portion of the house by sliding glass doors and a masonry fireplace wall. Sunspace ventilation is provided to the outside by awning windows located at the top and bottom of the south wall.

South facing windows provide direct gain solar heating to the dining area, kdtchen and master bedroom. The south glazing in the kdtchen and dining area provides heat to an exposed slab-on-grade finished with ceramic tile to provide direct gain heat storage.
The house faces 10 degrees to the east of true south.

The house is equipped with a celling fan to help reduce the air-conditioning load. North windows have an overhang with a projection factor of 0.30 . East and west windows are small and have no effective overhang because of the gable roof. South windows, including the sunspace windows, have an overhang with a projection factor of 0.20 .

Take-offs from the house are given in the worksheets. Refer to the circled values in the worksheet tables to locate where the various values which show up in the worksheets come from.

Performance is found to be satisfactory on all four worksheets. The bottom line on the work sheets, "comparison performance" refers to the house before the remodel.

$\mathrm{ACH}$.

REMODELED STRUCTRE

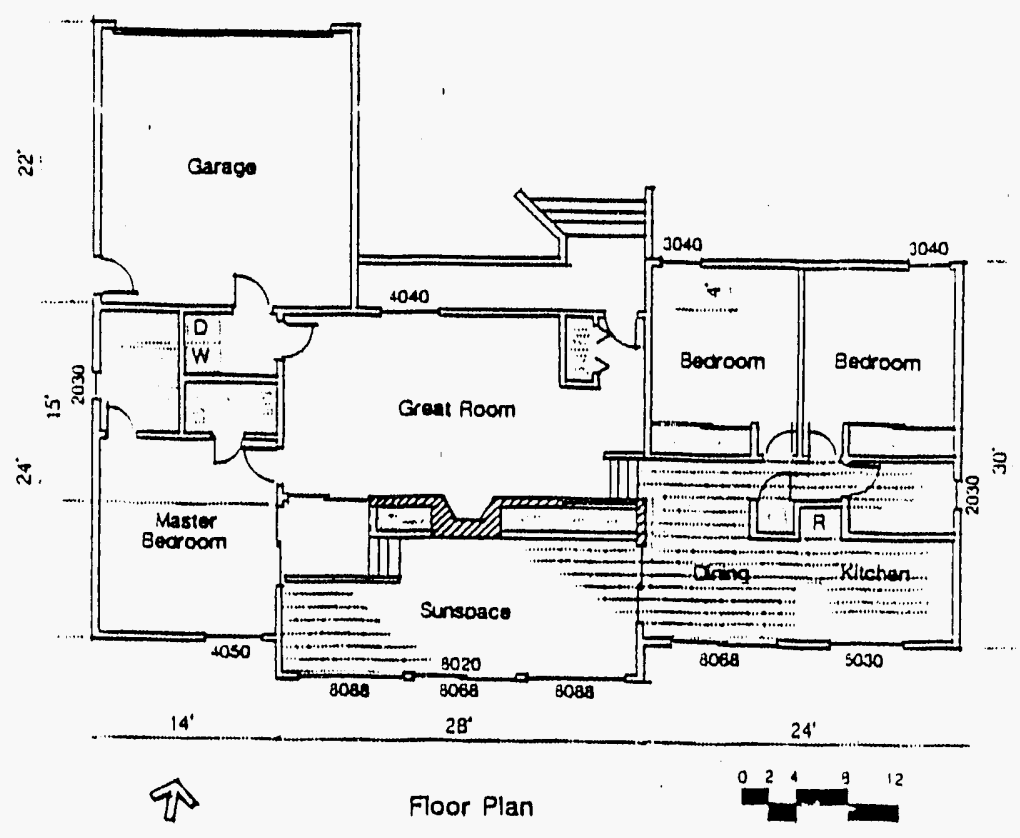




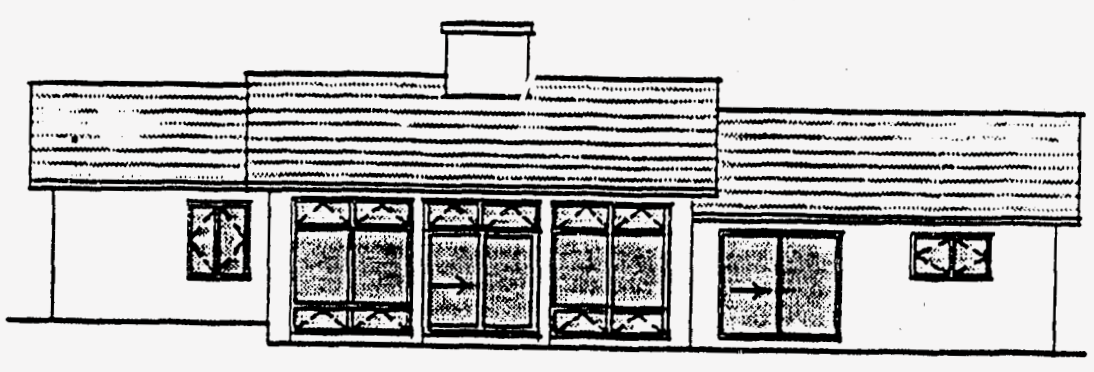

South Eevation
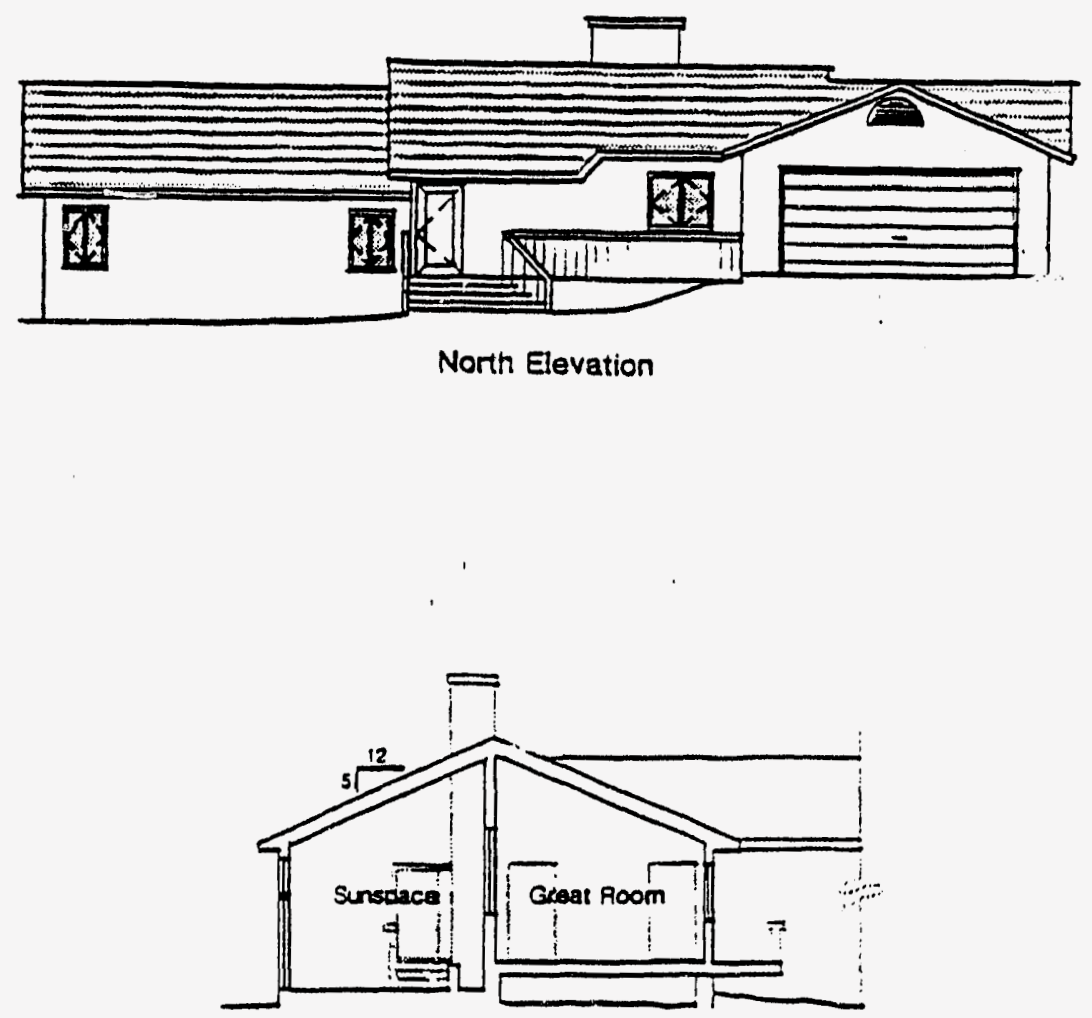

Section 


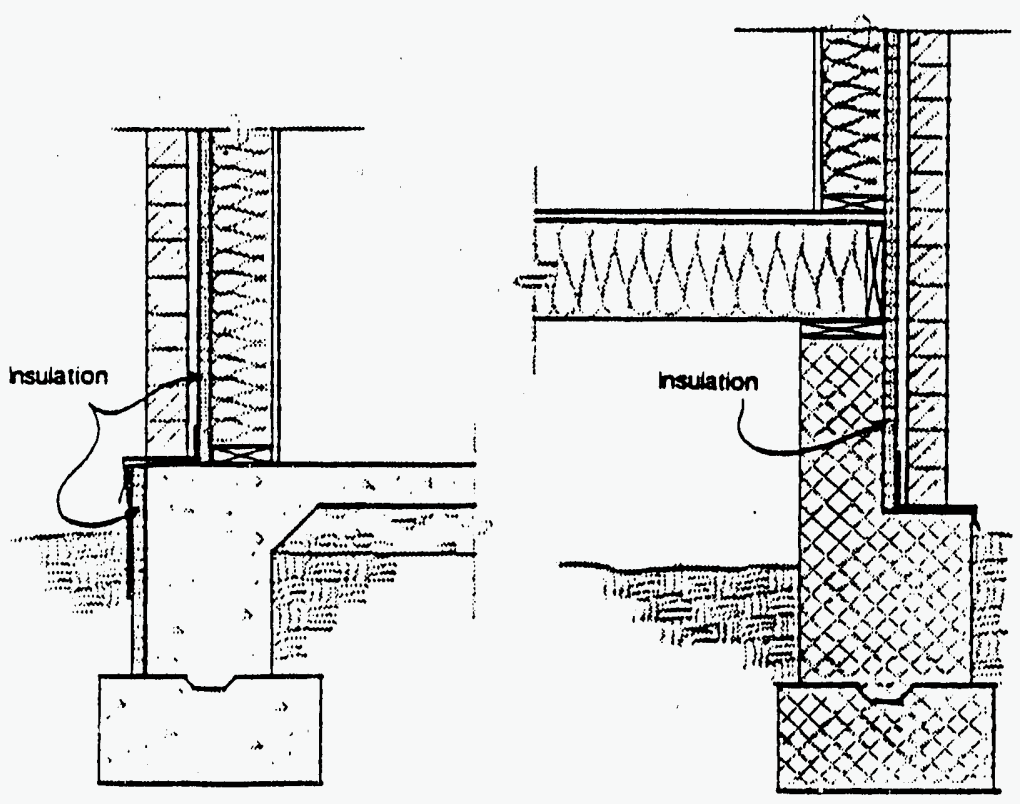


NOTE: These worksheets are completed for the example house described on the previous pages. Also the reference tables are marked up showing how the numbers are selected.

\section{Baltimore Maryland}

\section{Worksheets}




\section{General Project Information}

Proiact Name PASSIVE SOLAR REMOLEL Location BALTIVWORE, MO

Designer

Floor Area $\frac{1812}{\text { Date }} 11 / 7 / 91$

Date

\section{Worksheet I: Conservation Performance Level}

\section{A. Envelope Heat Loss}

\begin{tabular}{|c|c|c|c|c|c|}
\hline $\begin{array}{c}\text { Construction } \\
\text { Description } \\
\end{array}$ & Area & & $\begin{array}{c}\text { R-value } \\
\text { [Table A] }\end{array}$ & & $\begin{array}{l}\text { Heat } \\
\text { Loss } \\
\end{array}$ \\
\hline $\begin{array}{c}\text { Coilings/roofs R3O IN ATTKC-EXISTING + NEW } \\
R-19 \text { IN EXISTING CNTHEDRAL CEILSWYG }\end{array}$ & $\frac{1392}{420}$ & $\div$ & $\frac{27.9}{15.3}$ & $\begin{array}{l}= \\
=\end{array}$ & $\frac{50}{27}$ \\
\hline $\begin{array}{l}\text { Walls } R-\| l+R S \text { SHEATHING - REMODEL } \\
\text { R-II ELSEWHERE }\end{array}$ & $\frac{420}{792}$ & $\div$ & $\frac{17.0}{12.0}$ & $\begin{array}{l}= \\
=\end{array}$ & $\frac{25}{66}$ \\
\hline Insulated Floors & & + & & $=$ & \\
\hline Non-solar Glazing Double Glazing, $1 / 4$ sp. & 52 & + & 1.8 & $\begin{array}{l}= \\
=\end{array}$ & 29 \\
\hline Doors SOLID WOOD (WEATHER STRIPPED) & 40 & + & 2.2 & $\overline{=}$ & 18 \\
\hline
\end{tabular}

\section{B. Foundation Perimeter Heat Loss}

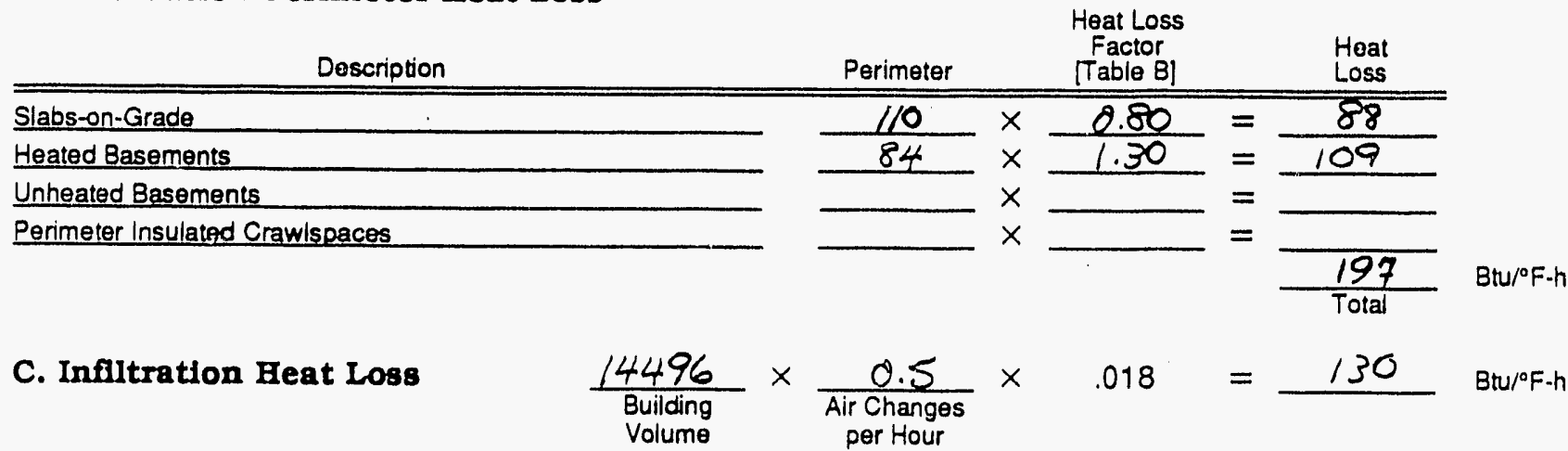

D. Total Heat Loss per Square Foot 24

$$
\times \frac{542}{\substack{\text { Total Heat Loss } \\(A+B+C)}} \div \frac{1504}{\text { Floor Area }}=-8.649 \text { Btu/DD-st }
$$

E. Conservation Performance Level

$$
\frac{8.469}{\begin{array}{c}
\text { Total Heat } \\
\text { Loss per } \\
\text { Square Foot }
\end{array}} \times \frac{4706}{\begin{array}{c}
\text { Heating Degree } \\
\text { Days [Table C] }
\end{array}} \times \frac{1.08}{\begin{array}{c}
\text { Heating Degree } \\
\text { Day Multiplier } \\
\text { Thable C] }
\end{array}}=\frac{43958}{\text { Btu/yr-st }}
$$

F. Comparison Conservation Performance (From Previous Calculation of from Table D) 


\section{Worksheet II: Auxiliary Heat Performance Level}

A. Projected Area of Passive Solar Glazing

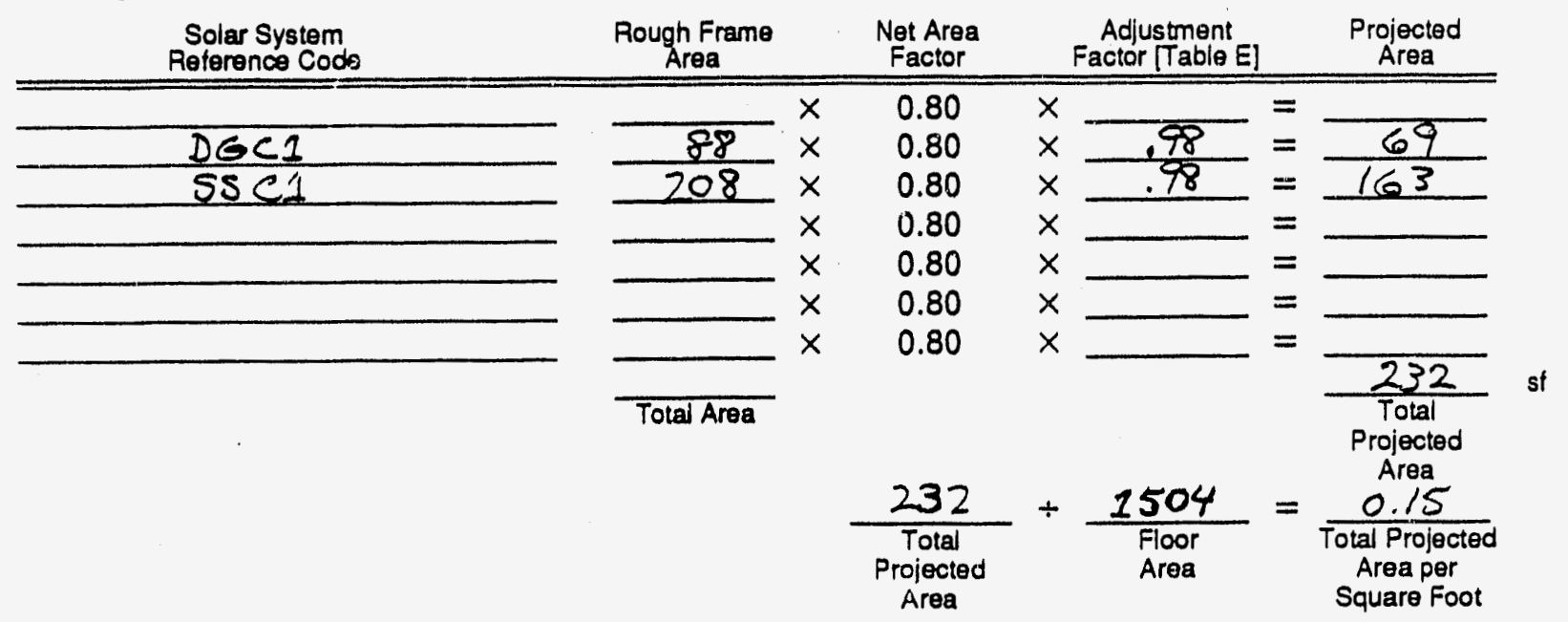

B. Load Collector Ratio

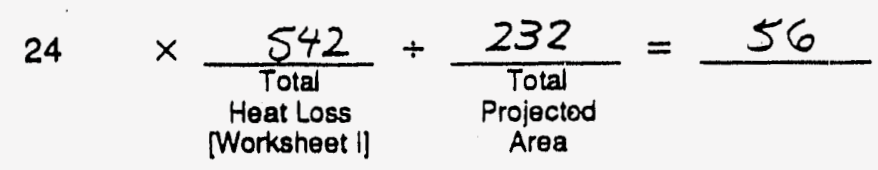

\section{Solar Savings Fraction}

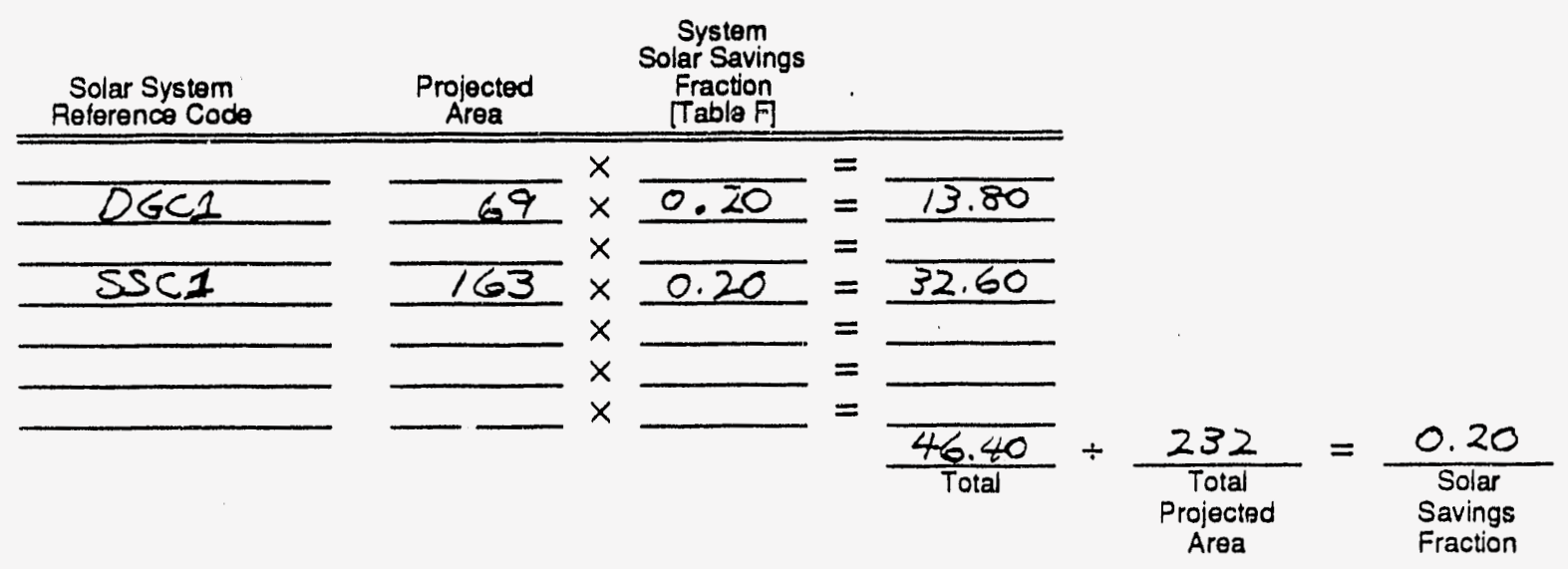

D. Auxdliary Heat Performance Level

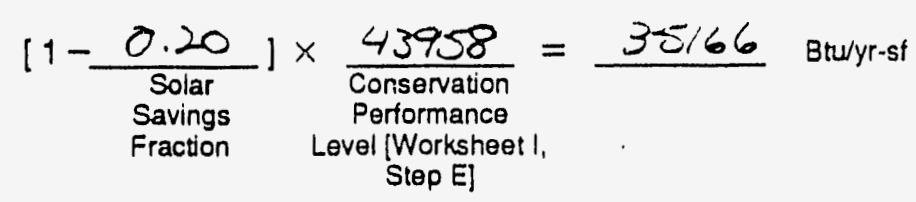

E. Comparative Aurdliary Eeat Performance (From Provious Calculation or from Table G)

64020 Btu/yr-sf 


\section{Worksheet III: Thermal Mass/Comfort}

A. Heat Capacity of Sheetrock and Interior Furnishings

\begin{tabular}{|c|c|c|c|c|c|}
\hline & Floor Area & & $\begin{array}{c}\text { Unit } \\
\text { Heat } \\
\text { Capacity }\end{array}$ & & $\begin{array}{c}\text { Total } \\
\text { Heat } \\
\text { Capacity }\end{array}$ \\
\hline Rooms with Direct Gain & 464 & $\bar{x}$ & $\overline{4.7}$ & $=$ & 2181 \\
\hline Spaces Connected to Direct Gain Spaces & 949 & $x$ & 4.5 & $=$ & 4271 \\
\hline
\end{tabular}

\section{B. Heat Capacity of Mlass Surfaces Enclosing Direct Gain Spaces}

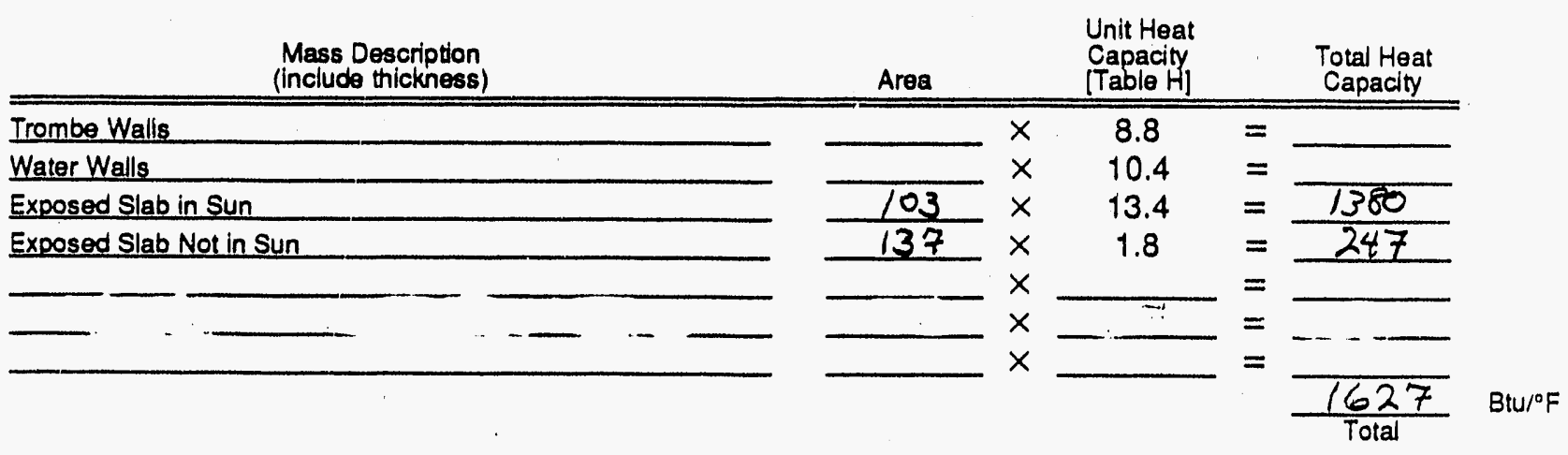

C. Heat Capacity of Mass Surfaces Enclosing Spaces Connected to Direct Gain Spaces

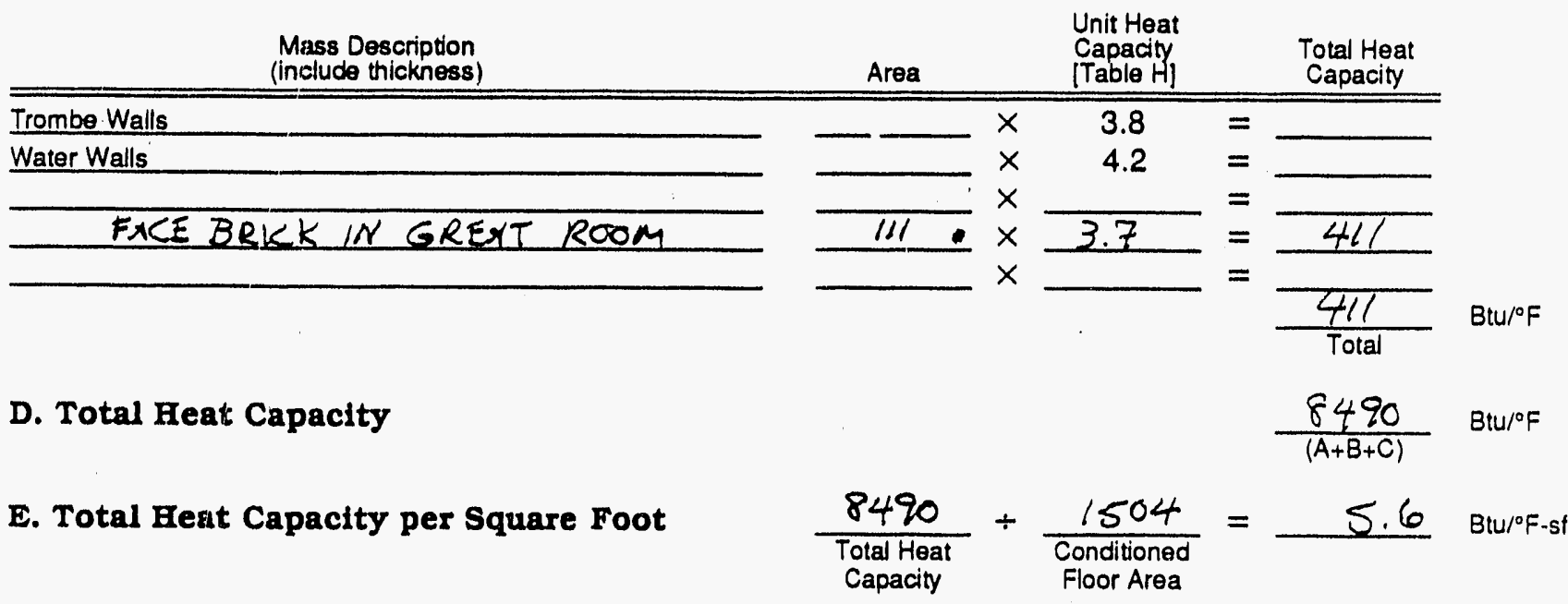

\section{F. Clear Winter Day Temperature Swing}

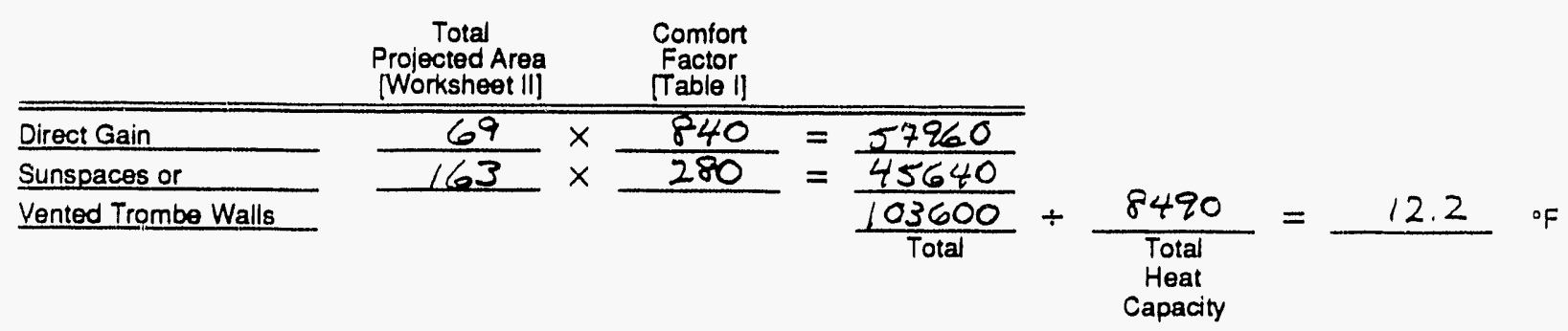

G. Recommended Maximum Temperature Swing

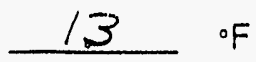

Compare Line $\mathrm{F}$ to Line $\mathrm{G}$ 
Worksheet IV: Summer Cooling Performance Leve1

A. Opaque Surfaces

\begin{tabular}{|c|c|c|c|c|c|c|c|c|c|}
\hline Description & $\begin{array}{l}\text { Heat Loss } \\
\text { Worksheet I] }\end{array}$ & & $\begin{array}{c}\text { Radiant Barrier } \\
\text { Factor } \\
{[\text { Table } \mathrm{J}]}\end{array}$ & & $\begin{array}{c}\text { Absorp- } \\
\text { tance } \\
\text { Table KI } \\
\end{array}$ & & $\begin{array}{c}\text { Heat Gain } \\
\text { Factor } \\
\text { Table LI } \\
\end{array}$ & & Load \\
\hline Ceilings/roots & 50 & $x$ & 1.00 & $x$ & 0.47 & $x$ & 45.7 & $=$ & 1074 \\
\hline & 27 & $x$ & 1.00 & $x$ & 0.47 & $x$ & 45.7 & $=$ & 580 \\
\hline & 78 & $x$ & & $x$ & 0.70 & $x$ & 23.2 & $=$ & 1267 \\
\hline Walls & 9 & $x$ & na & & 0.30 & $x$ & 23.2 & $=$ & 63 \\
\hline & & $x$ & na & & & $x$ & & $=$ & \\
\hline Doors & & $x$ & na & & & $x$ & & $=$ & \\
\hline
\end{tabular}

B. Non-solar Glazing

\begin{tabular}{|c|c|c|c|c|c|c|c|c|c|}
\hline Description & $\begin{array}{c}\text { Rough Frame } \\
\text { Area }\end{array}$ & & $\begin{array}{l}\text { Net Area } \\
\text { Factor }\end{array}$ & & $\begin{array}{c}\text { Shade Factor } \\
\text { [Table M] }\end{array}$ & & $\begin{array}{c}\text { Heat Gain } \\
\text { Factor [Table L }]\end{array}$ & & Load \\
\hline North Glass & 40 & $x$ & 0.80 & $x$ & 0.87 & $x$ & 34.5 & $=$ & 960 \\
\hline East Glass & 6 & $x$ & 0.80 & $x$ & 1.0 & $x$ & 63.2 & $=$ & 303 \\
\hline West Glass & 6 & $x$ & 0.80 & $x$ & 1.00 & $x$ & -67.8 & $=$ & 325 \\
\hline Skylights & & $x$ & 0.80 & $x$ & & $x$ & & $=$ & \\
\hline
\end{tabular}

\section{Solar Glazing}

\begin{tabular}{|c|c|c|c|c|c|c|c|c|c|}
\hline $\begin{array}{c}\text { Solar System } \\
\text { Description }\end{array}$ & $\begin{array}{c}\text { Rough Frame } \\
\text { Area }\end{array}$ & & $\begin{array}{c}\text { Net Area } \\
\text { Factor }\end{array}$ & & $\begin{array}{c}\text { Shade Factor } \\
\text { TTable M! }\end{array}$ & & $\begin{array}{c}\text { Hear Gain } \\
\text { Factor (Table L) } \\
\end{array}$ & & Load \\
\hline Direct Gain & 88 & $x$ & 0.80 & $x$ & 0.860 & $x$ & 55.5 & $=$ & 3360 \\
\hline Storage Walls & 208 & $x$ & 0.80 & $\times$ & 0.86 & $x$ & 11.2 & $=$ & 1603 \\
\hline Sunspace & & $\times$ & 0.80 & $x$ & & $x$ & & $=$ & \\
\hline & & $x$ & 0.80 & $x$ & & $x$ & & $=$ & \\
\hline & & & & & & & & & Total \\
\hline D. Internal Galn & & & 2040 & t & 850 & $x$ & 3 & $=$ & 4590 \\
\hline & . & & $\begin{array}{l}\text { Constant } \\
\text { Component } \\
\text { [Table N] }\end{array}$ & & $\begin{array}{c}\text { Variable } \\
\text { Component } \\
\text { Table N] }\end{array}$ & & $\begin{array}{l}\text { Number of } \\
\text { Bedrooms }\end{array}$ & & \\
\hline
\end{tabular}

E. Coollng Load per Square Foot $\quad 1,000 \times \frac{14 / 25}{(A+B+C+D)} \div \frac{1504}{\text { Floor Area }}=9392$ Btu/yr-st

F. Adjustment for Thermal Mass and Ventllation

$\frac{4303}{\text { Thable Ol }}$ Bu/yr-st

G. Coolling Performance Level

$\frac{5089}{(E \cdot F)}$ Bturyr-5t

B. Comparison Coollng Performance (From Previous Calaulabon of item Tade P)

120813 3tulyr-si

Compare Line $G$ to Line $H$ 


\begin{tabular}{|c|c|c|c|c|}
\hline \multicolumn{5}{|c|}{$\begin{array}{c}\text { Table A-Equivalent Thermal } \\
\text { Performance of Acemblies } \\
\text { R-values (hr-F-af/Btu) }\end{array}$} \\
\hline \multicolumn{5}{|c|}{ A1-Collinge/Rools } \\
\hline $\begin{array}{l}\text { Attic Truss } \\
\text { Construetion }\end{array}$ & $R \cdot 19$ & $\begin{array}{l}\text { Insulation } \\
\text { R-30 }\end{array}$ & $\begin{array}{l}\text { R-value } \\
\text { R-49 }\end{array}$ & $A-60$ \\
\hline & 17.4 & 27.9 & 46.9 & 57.9 \\
\hline $\begin{array}{l}\text { Framed Ratter } \\
\text { Construetion }\end{array}$ & R-11 & $\begin{array}{l}\text { insulation } \\
R-19\end{array}$ & $\begin{array}{l}\text { Revalue } \\
\text { R-30 }\end{array}$ & R.38 \\
\hline $\begin{array}{l}2 \times 6 \text { at } 16^{\circ} \circ c \\
2 \times 6 \text { at } 24^{\prime \prime} \circ c \\
2 \times 8 \text { at } 16^{\circ} \circ c \\
2 \times 8 \text { at } 24^{\circ} \circ c \\
2 \times 10 \text { at } 16^{\circ} \infty c \\
2 \times 10 \text { at } 24^{\prime \prime} \infty c \\
2 \times 12 \text { at } 16^{\circ} \infty c \\
2 \times 12 \text { at } 24^{\circ} \infty\end{array}$ & $\begin{array}{l}10.2 \\
10.4 \\
10.7 \\
10.8 \\
11.2 \\
11.2 \\
11.7 \\
11.5\end{array}$ & $\begin{array}{l}\frac{11.7}{15.33} \\
77.0 \\
17.6 \\
18.1 \\
18.4 \\
18.8 \\
19.0\end{array}$ & $\begin{array}{l}16.3 \\
17.1 \\
20.6 \\
21.6 \\
24.5 \\
25.5 \\
25.5 \\
27.3\end{array}$ & $\begin{array}{l}\bar{z} \\
21.1 \\
22.2 \\
25.7 \\
26.8 \\
30.1 \\
31.4\end{array}$ \\
\hline
\end{tabular}

\section{A2-Framod Wallo}

Single

Framing

$2 \times 4$ al $16^{\prime \prime} 00$

$2 \times 4$ at $24^{400}$

$2 \times 6$ at $16^{\circ} 0 c$

$2 \times 6$ at $24^{\circ} 0 \mathrm{C}$

Double

Wail

Framing

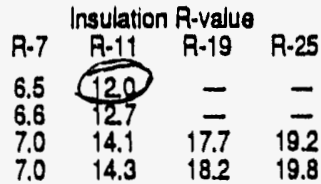

Total Thickness (inches) $\begin{array}{cccc}8 & 10 & 12 & 14\end{array}$

The $P$-value of insulating sheathing should be added to the values in this table.

\section{R-5 JHEATHIIVC}

A3r-insulated Floors

Framing

$2 \times 6 s$ at $16 " 00$

$2 \times 6$ s at $24^{\circ} \infty$

$2 \times 8$ s at $16^{4} \propto$

$2 \times 8 s$ at $24^{\circ} \infty$

$2 \times 10$ at $16^{\circ} \circ$

$2 \times 10$ at $24^{\circ} \infty$

$2 \times 12$ at $16^{\circ} \infty$

$2 \times 12$ at $24^{\circ} \infty$

These R-values include the buffering effect of a

ventilated crawlspace or unconditioned basement

\begin{tabular}{|c|c|c|c|}
\hline \multicolumn{4}{|c|}{ A4-Windows } \\
\hline & $\begin{array}{l}\text { Wood } \\
\text { Frame }\end{array}$ & $\begin{array}{c}\text { Standard } \\
\text { Metal } \\
\text { Frame }\end{array}$ & $\begin{array}{c}\text { Metal } \\
\text { Framaw/ } \\
\text { Thermal } \\
\text { Break }\end{array}$ \\
\hline \multirow{2}{*}{$\begin{array}{l}\text { Double } \\
1 / 4^{*} \text { soace } \\
1 / 2^{\circ} \text { space } \\
\text { Low- } \\
\text { Triple } \\
1 / 4^{*} \text { space } \\
1 / 2^{\circ} \text { space }\end{array}$} & $\begin{array}{l}\frac{1.0}{3.1} \\
3.1\end{array}$ & $\begin{array}{l}1.4 \\
1.6 \\
2.2\end{array}$ & $\begin{array}{l}1.5 \\
1.8 \\
3.0\end{array}$ \\
\hline & $\begin{array}{l}2.7 \\
3.3\end{array}$ & $\begin{array}{l}1.8 \\
2.2\end{array}$ & $\begin{array}{l}21 \\
27\end{array}$ \\
\hline \multicolumn{4}{|c|}{$\begin{array}{l}\text { These R.values are for the entre rough frame window } \\
\text { ocening. When storm sash is added, an additional } 1.1 \\
\text { may be aoded. One naif the R.value of moveable } \\
\text { nsulation may also be added, when aopropnale. }\end{array}$} \\
\hline
\end{tabular}

Table A-continued ..

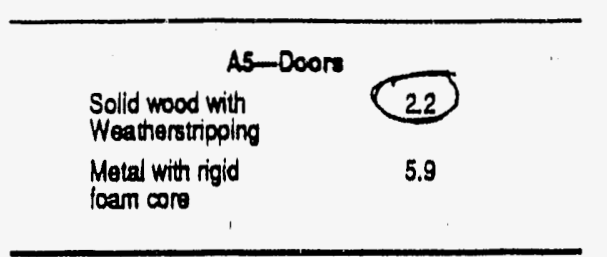

Table B-Peximeter Hent Los

Fuctors for Slabe-on-Grade and

Unhented Basementu (Btu/h-F-ft)

\begin{tabular}{|c|c|c|c|c|}
\hline $\begin{array}{l}\text { Perimeter } \\
\text { insulation }\end{array}$ & $\begin{array}{l}\text { Slabs-ón- } \\
\text { Grade }\end{array}$ & $\begin{array}{l}\text { Heatod } \\
\text { Baso- } \\
\text { ments }\end{array}$ & $\begin{array}{l}\text { Unheated } \\
\text { Baso- } \\
\text { men's }\end{array}$ & $\begin{array}{l}\text { Insulatec } \\
\text { Crawt- } \\
\text { spaces }\end{array}$ \\
\hline $\begin{array}{l}\text { None } \\
\text { R-5 } \\
R-7 \\
\text { R. } 11 \\
\text { R-19 } \\
\text { R-30 }\end{array}$ & $\begin{array}{l}0.8 \\
0.4 \\
0.3 \\
0.3 \\
0.2 \\
0.1\end{array}$ & $\begin{array}{l}1.3 \\
0.8 \\
0.7 \\
0.6 \\
0.4 \\
0.3\end{array}$ & $\begin{array}{l}1.1 \\
0.7 \\
0.6 \\
0.5 \\
0.5 \\
0.4\end{array}$ & $\begin{array}{l}1.1 \\
0.6 \\
0.5 \\
0.4 \\
0.3 \\
0.2\end{array}$ \\
\hline
\end{tabular}

\begin{tabular}{|c|c|c|c|c|c|}
\hline \multicolumn{6}{|c|}{$\begin{array}{c}\text { Table C-Heating Degree Days } \\
\text { (F-day) }\end{array}$} \\
\hline \multicolumn{6}{|c|}{ CI-Heating Degreo Daye (Base 65\% } \\
\hline \multicolumn{6}{|c|}{ Baltimore } \\
\hline \multicolumn{6}{|c|}{ C2-Heating Degree Day Multipllor } \\
\hline $\begin{array}{l}\text { Heat Loss } \\
\text { per Square } \\
\text { Foot }\end{array}$ &.$\infty$ & & sive So & .15 & .20 \\
\hline $\begin{array}{l}12.00 \\
11.50 \\
11.00 \\
10.50 \\
10.00 \\
9.50 \\
9.00 \\
8.50 \\
8.00 \\
7.50 \\
7.00 \\
6.50 \\
6.00 \\
5.50 \\
5.00 \\
4.50 \\
4.00 \\
3.50 \\
3.00 \\
2.50 \\
2.00\end{array}$ & $\begin{array}{l}1.10 \\
1.10 \\
1.09 \\
1.08 \\
1.07 \\
1.06 \\
1.05 \\
1.04 \\
1.03 \\
1.01 \\
0.99 \\
0.97 \\
0.95 \\
0.93 \\
0.90 \\
0.86 \\
0.82 \\
0.77 \\
0.70 \\
0.60 \\
0.47\end{array}$ & $\begin{array}{l}1.11 \\
1.10 \\
1.10 \\
1.09 \\
1.08 \\
1.07 \\
1.07 \\
1.05 \\
1.04 \\
1.03 \\
1.01 \\
1.00 \\
0.98 \\
0.96 \\
0.93 \\
0.91 \\
0.87 \\
0.83 \\
0.78 \\
0.71 \\
0.61\end{array}$ & $\begin{array}{l}1.12 \\
1.11 \\
1.11 \\
1.10 \\
1.09 \\
1.09 \\
1.08 \\
1.07 \\
1.06 \\
1.05 \\
1.03 \\
1.02 \\
1.00 \\
0.98 \\
0.96 \\
0.94 \\
0.91 \\
0.88 \\
0.84 \\
0.79 \\
0.73\end{array}$ & $\begin{array}{l}1.12 \\
1.12 \\
1.11 \\
1.11 \\
1.10 \\
1.09 \\
1.09 \\
1.08 \\
1.07 \\
1.06 \\
1.05 \\
1.04 \\
1.02 \\
1.00 \\
0.98 \\
0.96 \\
0.94 \\
0.92 \\
0.89 \\
0.85 \\
0.80\end{array}$ & $\begin{array}{l}1.13 \\
1.12 \\
1.12 \\
1.11 \\
1.11 \\
1.10 \\
1.10 \\
1.09 \\
1.08 \\
1.07 \\
1.06 \\
1.05 \\
1.04 \\
1.02 \\
1.01 \\
0.99 \\
0.97 \\
0.95 \\
0.92 \\
0.89 \\
0.86\end{array}$ \\
\hline
\end{tabular}

Table D-Base Case Conservation Performance (Btu/yr-5f)

Base Case 66,228

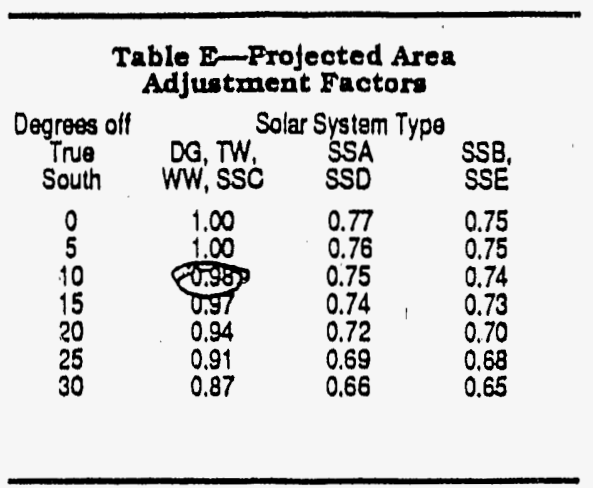

Table F-Solar System Saving Fractions

\begin{tabular}{cccc}
\multicolumn{4}{c}{ F1-Dlrect Gain } \\
$\begin{array}{c}\text { Load } \\
\text { Collector } \\
\text { Ratio }\end{array}$ & $\begin{array}{c}\text { DGC1 } \\
\text { Double } \\
\text { Glazing }\end{array}$ & $\begin{array}{c}\text { Low- } \\
\text { Glazing }\end{array}$ & $\begin{array}{c}\text { DGC } \\
\text { R-9 Night } \\
\text { Insulation }\end{array}$ \\
400 & 0.04 & 0.04 & 0.05 \\
300 & 0.04 & 0.05 & 0.07 \\
200 & 0.06 & 0.08 & 0.10 \\
150 & 0.08 & 0.10 & 0.12 \\
100 & 0.11 & 0.14 & 0.18 \\
80 & 0.13 & 0.17 & 0.21 \\
60 & 0.17 & 0.21 & 0.27 \\
58 & 0.19 & 0.25 & 0.32 \\
45 & 0.20 & 0.27 & 0.35 \\
40 & 0.22 & 0.29 & 0.38 \\
35 & 0.24 & 0.33 & 0.42 \\
30 & 0.27 & 0.36 & 0.47 \\
25 & 0.30 & 0.41 & 0.54 \\
20 & 0.34 & 0.48 & 0.61 \\
15 & 0.39 & 0.56 & 0.72 \\
& & & \\
\hline
\end{tabular}

\begin{tabular}{|c|c|c|c|c|}
\hline \multicolumn{5}{|c|}{ F2-Trombe Walls } \\
\hline $\begin{array}{l}\text { Load } \\
\text { Collector } \\
\text { Ratio }\end{array}$ & $\begin{array}{l}\text { TWF3 } \\
\text { Unvented } \\
\text { Non- } \\
\text { selective }\end{array}$ & $\begin{array}{c}\text { TWA3 } \\
\text { Vented } \\
\text { Non- } \\
\text { selecilve }\end{array}$ & $\begin{array}{l}\text { TWJ2 } \\
\text { Unvented } \\
\text { Solec- } \\
\text { tive }\end{array}$ & $\begin{array}{c}\text { TWL } \\
\text { Unvented } \\
\text { Night } \\
\text { Insulation }\end{array}$ \\
\hline $\begin{array}{l}400 \\
300 \\
200 \\
150 \\
100 \\
80 \\
60 \\
50 \\
45 \\
40 \\
35 \\
30 \\
25 \\
20 \\
15\end{array}$ & $\begin{array}{l}0.02 \\
0.03 \\
0.05 \\
0.07 \\
0.10 \\
0.13 \\
0.16 \\
0.19 \\
0.21 \\
0.23 \\
0.25 \\
0.28 \\
0.32 \\
0.37 \\
0.44\end{array}$ & $\begin{array}{l}0.05 \\
0.06 \\
0.08 \\
0.10 \\
0.13 \\
0.16 \\
0.20 \\
0.22 \\
0.24 \\
0.26 \\
0.29 \\
0.32 \\
0.36 \\
0.41 \\
0.48\end{array}$ & $\begin{array}{l}0.02 \\
0.04 \\
0.08 \\
0.12 \\
0.19 \\
0.24 \\
0.30 \\
0.35 \\
0.38 \\
0.42 \\
0.46 \\
0.51 \\
0.57 \\
0.64 \\
0.73\end{array}$ & $\begin{array}{l}0.00 \\
0.01 \\
0.05 \\
0.08 \\
0.14 \\
0.18 \\
0.24 \\
0.29 \\
0.31 \\
0.35 \\
0.39 \\
0.43 \\
0.49 \\
0.56 \\
0.66\end{array}$ \\
\hline
\end{tabular}




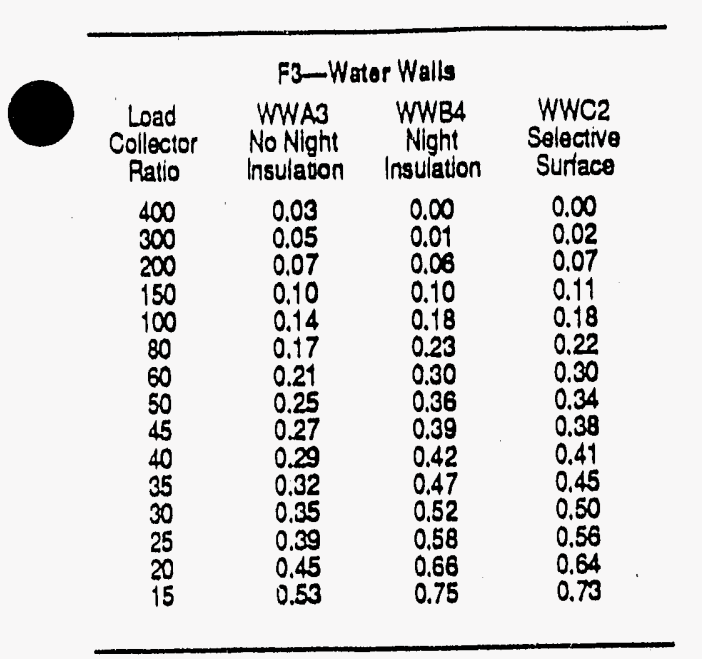

\begin{tabular}{|c|c|c|c|c|c|}
\hline \multicolumn{6}{|c|}{ F4-Sumperes } \\
\hline $\begin{array}{l}\text { Load } \\
\text { Collecto } \\
\text { Ratio }\end{array}$ & SSA1 & SSB1 & $\begin{array}{c}\text { nspace } \\
\text { SSC1 }\end{array}$ & $\begin{array}{l}Y P{ }^{\prime} \\
\text { SSD1 }\end{array}$ & SSE1 \\
\hline $\begin{array}{l}400 \\
300 \\
200 \\
150 \\
100 \\
80 \\
100 \\
50 \\
45 \\
40 \\
35 \\
30 \\
25 \\
20 \\
15\end{array}$ & $\begin{array}{l}0.09 \\
0.11 \\
0.13 \\
0.15 \\
0.19 \\
0.22 \\
0.26 \\
0.29 \\
0.31 \\
0.33 \\
0.35 \\
0.38 \\
0.42 \\
0.47 \\
0.53\end{array}$ & $\begin{array}{l}0.07 \\
0.09 \\
0.11 \\
0.12 \\
0.16 \\
0.18 \\
0.22 \\
0.24 \\
0.26 \\
0.28 \\
0.30 \\
0.33 \\
0.36 \\
0.41 \\
0.47\end{array}$ & $\begin{array}{l}0.03 \\
0.05 \\
0.07 \\
0.09 \\
0.12 \\
0.15 \\
0.178 \\
6.21 \\
0.23 \\
0.25 \\
0.27 \\
0.30 \\
0.34 \\
0.39 \\
0.46\end{array}$ & $\begin{array}{l}0.08 \\
0.10 \\
0.13 \\
0.16 \\
.21 \\
0.25 \\
0.30 \\
0.34 \\
0.36 \\
0.38 \\
0.41 \\
0.45 \\
0.49 \\
0.55 \\
0.62\end{array}$ & $\begin{array}{l}0.06 \\
0.08 \\
0.10 \\
0.13 \\
0.17 \\
0.20 \\
0.25 \\
0.28 \\
0.30 \\
0.32 \\
0.35 \\
0.38 \\
0.42 \\
0.47 \\
0.53\end{array}$ \\
\hline
\end{tabular}
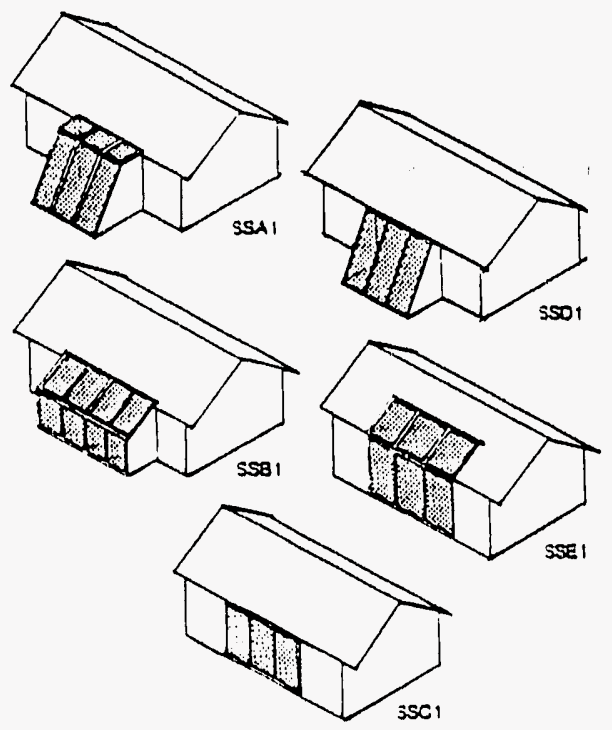

Table G-Base Case Auriliary Heat Performance (Btu/gr-sh) Base Case .64.020

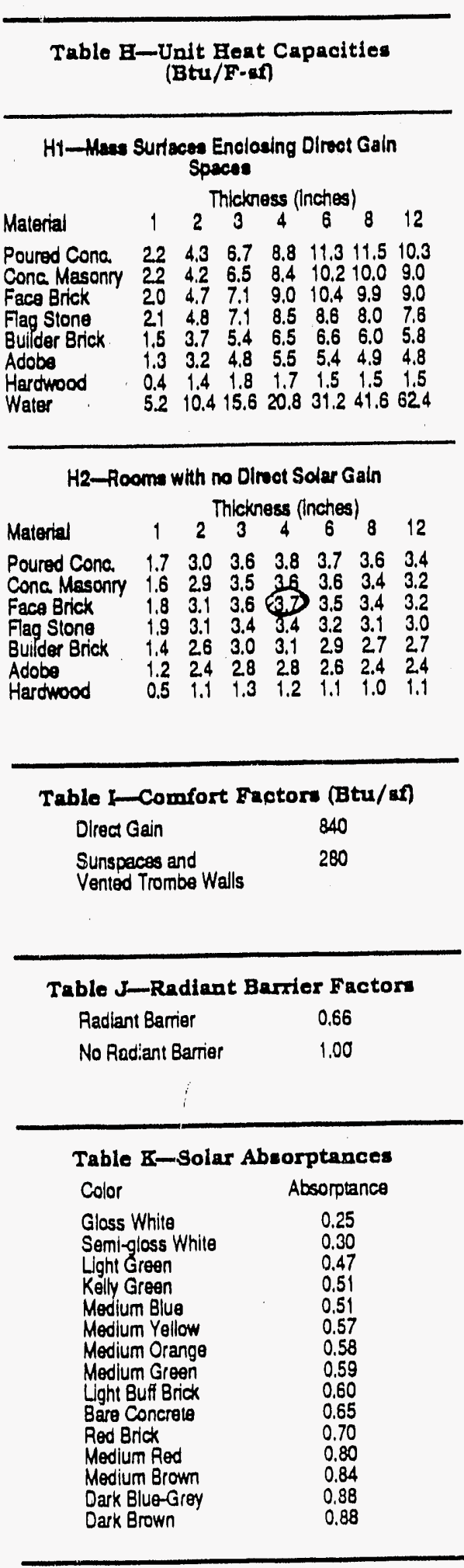

Table L-Feat Gain Faotors

Ceilling/rools

Walls and Doors

North Glass

Wast Glass

Skyllights

Direct Gain Glazing

Trombo Walls and

Water Walls

Sunspaces

SSA1

SSB1

SSC1

SSD 1

SSE 1

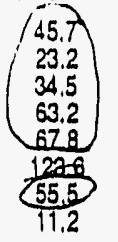

$\frac{55.5}{11.2}$

33.0
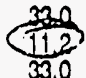

33.0

\begin{tabular}{|c|c|c|c|c|}
\hline \multicolumn{5}{|c|}{ Table M-shading Factor } \\
\hline $\begin{array}{l}\text { Projection } \\
\text { Factor }\end{array}$ & South & $\mathrm{Ea}$ & North & $W_{0}$ \\
\hline $\begin{array}{l}0.00 \\
0.20 \\
0.40 \\
0.60 \\
0.80 \\
1.00 \\
1.20\end{array}$ & $\begin{array}{l}1.00 \\
0.86 \\
0.66 \\
0.50 \\
0.34 \\
0.29 \\
0.24\end{array}$ & $\begin{array}{l}0.98 \\
0.83 \\
0.71 \\
0.60 \\
0.50 \\
0.40\end{array}$ & $\begin{array}{l}100 \\
0.92 \\
0.83 \\
0.75 \\
0.66 \\
0.57 \\
0.49\end{array}$ & $\begin{array}{l}0.94 \\
0.83 \\
0.71 \\
0.60 \\
0.50 \\
0.40\end{array}$ \\
\hline
\end{tabular}

Table N-Internal Gain Factor Constant Componen $2040 \times B$ Buyr Variable Componen $850 / k B t U y r-B R$

Table O-Thermal Mass and Ventilation Adjustment (Btu/yr-sf)

Total Heat Night Night No Night No Night Capacity Ventw/ Ventw/No Ventw/ Ventw/No per SF Cail. Fan Cail. Fan Cail. Fan Ceil. Fan

$\begin{array}{rrrrr}0.0 & 3,480 & 1,010 & 1,820 & .1,190 \\ 1.0 & 4,780 & 2,400 & 3,110 & 190 \\ 2.0 & 5,410 & 3,130 & 3,750 & 930 \\ 3.0 & 5,710 & 3,530 & 4,050 & 1,320 \\ 4.0 & 5,860 & 3,740 & 4,200 & 1,530 \\ 5.0 & 5,940 & 3,850 & 14,280 & 1,640 \\ 6.0 & 5,970 & 3,910 & 4,310 & 1,700 \\ 7.6 & 5,990 & 3,940 & 4,330 & 1,730 \\ 8.0 & 6,000 & 3,960 & 4,340 & 1,750 \\ 9.0 & 6,000 & 3,970 & 4,340 & 1,760 \\ 10.0 & 6,010 & 3,970 & 4,340 & 1,770\end{array}$

Total heat capacity per square loot is calculated on Worksheot III, Slep E

Table P-Base Case Cooling Performance (Btu/sf-ge) Base Case 12,031 


\section{Clossary}

Auxiliary Beating Syotem: a term for the system (gas, electric, oll, etc.) which provides the non-solar portion of the house's heating energy needs, referred to as the "auxdlary heat."

British Thermal Unit (Btu): a unit used to measure heat. One Btu is about equal to the heat released from burning one kdtchen match.

Conservation: in addition to energy conservation in the general sense, the term is used to refer to the non-solar, energy-saving measures in a house which are primarlly involved with Improving the bullding envelope to guard against heat loss -- the insulation, the air inflitration reduction measures, and so forth.

Direct Gain: a passive solar system in which the sunirght falls directly into the space where it is stored and used.

Glazing: often used interchangeably with window or glass, the term actually refers to specifically just to the clear material which admits sunilght, and so can also be plastic. Double and triple glazing refer to two or three panes.

Indirect Gain: a passive solar system in which the sunlight falls onto thermal mass which is positioned between the glazing and the space to be heated, 1.e. a Thermal Storage Wall or Trombe Wall.

Low-Emissivity: the term refers to a surface's ability to absorb and re-radiate heat. A materlal with a low emissivity absorbs and re-radiates relatively small amounts of heat. Low-emissivity or "low$e^{\prime \prime}$ glass sandwiches a thin layer of metallic fim or coating between two panes of glass. The low- glass blocks radiant heat, so it will tend to keep heat energy inside the house during the winter, and keep heat energy outside the house during the summer.
Pawaive solar: design and construction techniques which help a bullding make use of solar energy by non-mechanical means, as opposed to active solar techniques which use equipment such as roof-top collectors.

Phaso-Change Materials: materials such as salts or waxes which store and release energy by changing "phase"; most store energy when they turn liquid at a certain temperature and release energy when they turn solid at a certain temperature, but some remain solid but undergo chemical changes which store and release energy. Phase change materials can be used as thermal mass but few products are commercially avallable at this time.

Purchased Energy: although the terms are often used interchangably, a house's "purchased energy" is generally greater than Its "auxdlary heat" because heating systems are seldom $100 \%$ efficient, and more energy is purchased than is actually dellvered to the house.

R-Values a unit that measures the resistance to heat flow through a glven matertal. The higher the R-value, the better insulating capability the material has. The R-value is the reciprocal of the $U$-value. (see below)

Radiant Barrier: reflective materlal used in hot cllmates to block radiant heat, particularly in a house's roof.

Shading Coefflient: a measure of how much solar heat will be transmitted by a glazing matertal, as compared to a single pane of clear uncoated glass, which has a shading coefficient (SC) of 1. For example, clear double-pane glass might have an SC in the range of .88 .

Reflective glass might have SC's of .03.06. In general, lower shading coefficients are desirable when heat gain is a problem.

Sunspace: passive solar system sometimes also referred to as an isolated gain system, where sunlight is collected and stored in a space separate from the living space, and must be transferred there elther by natural convection or by fans.
Suntempering: a modest form of a direct gain passive solar system; suntempered houses increase south-facing glass to about 7 percent of a total floor area, but add no thermal mass beyond the "free" mass already in a typical house -. gypsum board, framing, conventional furnishings and floor coverings.

Temperature Swing: a measure of the number of degrees the temperature in a space will vary during the course of a sunny winter day without the furnace operating; an indicator of the amount of thermal mass in the passive solar system.

Thermul Mases: matertal that stores energy, although mass will also retain coolness. The thermal storage capacity of a matertal is a measure of the material's abllity to absorb and store heat. Thermal mass in passive solar bulldings is usually dense materlal such as brick or concrete masonry, but can also be thle, water, phase change materials, etc.

Thermal storage Wall: a passive solar system also sometimes called Trombe Wall or indirect gain system; a soithfacing glazed wall, usually made of masonry but can also be made of contalners of water.

Trombe Wall: a thermal storage wall, referred to by the name of its inventor, Dr. Fellx Trombe.

U-Value: a unit representing the heat loss per square foot of surface area per degree $F$ of temperature difference (see $\mathrm{R}$-value above). 


\section{References}

\section{General}

1. A Sunbullder's Prtmer, National Renewablc Energy Laboratory - NREL (formerly SERl).

2. Passtue: It's a Natural, NREL.

3. The Passive Solar Construction Handbook, Steven Winter Associates/Northeast Solar Energy Center/Natlonal Concrete Masunry Association/Portland Cement Association/Brick Institute of America. Avallable for $\$ 29.95$ plus $\$ 3.00$ handling, from Steven Winter Assoctates, Attn: Publications, 6100 Emplre State Bullding, New York, N.Y. 10001

4. Suntempering in the Northeast, Steven Winter Associates. Avallable from them at the address above for $\$ 9.50$.

5. Balcomb, U.D. Passive Solar Design Handbook, Volume I. II, III. Avallable from National Technical Information Service, U.S. Dept. of Commerce, 5285 Port Royal Road, Springfield, Va, 22161, $\$ 32.00$ each for I and II, $\$ 12.00$ for III.

6. Jones, R, et al. Passive Solar Heating Analysis. This volume supercedes and expands Volume II, III, and supplements of the Passive Solar Design Handbook (Ref, 5). Avallable from ASHRAE, Publications, 1791 Tullie Circle NE. Atlanta, Ga, 30329, $\$ 30.00$ for ASHRAE members, $\$ 60.00$ for non-members.

7. Llving With the sun (for consumers) and Bullding With the Sun (for bullders), PPG Industries.

8. The Passive Solar Information Guide, PSIC.

9. Passive Solar Trends. Technical briefs from PSIC.

a. Inflitration in Passive Solar Construction

b. The State of the Art in Passive Solar Construction

c. Passive Solar in Factory-Built Housing

d. Radlant Barters: Top Performers in Hot Cllmates e. 'Glazings: The Design Considerations Aren't As Clear As Glass

f. Ideas for Passive Solar Remodeling

g. Passive Homes in the Marketplace (Class C Studies)

h. Daylighting in Commerolal Bulldings

1. Human Comfort and Passive Solar Design

J. Passtve Design for Commercial Bulldings

k. Passtve Solar: Princlples and Products

1. Increasing Design Flexibillty

m. Utllitles and Passive: Predicting the Pay-off

\section{Insulation}

10. NAHB Insulation Manual, National Assockation of Home Bullders, National Research Center. Avallable from NAHB Bookstore, 15th and M Streets N.W., Washington, D.C. 20005. (202) 8220200 .

11. Luschkofi, James $\mathrm{K}$. The Aurtight: House: Using the Altight Drywall Approach, lowa State University Research Foundation. Avallable for \$14.95; Attn: Sarah Terrones, EES Bullding, lowa State Uriversity, Ames, LA. 50011

\section{Appliances}

12. Saiving Energy and Money with Home Appliances, Environmental Sclence Department, Massachusetts Audobon Soclety/American Council for an Energy Emcient Economy, Avallable for $\$ 2.00$ apiece from ACEE, 1001 Connecticut Ave. N.W., Suite 535, Washington D.C. 20036
13. Wilson, Alex. Consumer Guide to Home Energy Efficiency. American Counoll for an Energy Emclent Economy. Washington, DC.

\section{Energy Efflcient Construction}

14. Boe, B. and L. Schwartz, T. Porterfield, Builder's Fleld Guide to Energy Efficient Construction DOE/BP. 1427: October 1990. Oregon State University, Corvallis, OR 97331.

\section{Slte Planning}

15. Bullder's Guide to Passive Solar Home Design and Land Development. National Fenestration Counctl. Avallable for $\$ 12.00$ from NFC, 3310 Harrison. White Lakes Professional Bullding, Topeka, KS. 66611

16. Site Planning for Solar Access, U.S. Department of Housing and Urban Development/American Planning Assoctation. Avallable for $\$ 6.50$ from Superintendent of Documents, U.S. Government Printing Office, Washington D.C. 20402

\section{Sunspaces}

17. Jones, Robert W. and Robert D. McFarland. The Sunspace Primer: A Guide for Passive Solar Heattng, avallable for \$32.50 from Van Nostrand Reinhold, 1155 th Avenue, New York, N.Y. 10003

18. Greenthouses for Living, from Steven Winter Associates, Attn: Publications, 6100 Empire State Bullding, New York, N.Y. $10001, \$ 6.95$.

19. Concept $I V$, from Andersen Corporation, Bayport, MN. 55003, \$6.95.

20. Passive Solar Greenhouse Design and Construction, Ohio Department of Energy/John Spears, 8821 Suver Spring, Md., 20910. 


\section{More Information}

Conservation and Renewable Energy Inquiries and Referral Service (CARERR) 1-800-523-2929, Renewable Energy Information, Box 8900, Sllver Spring, Md. 20907

National Awocintion of Bome Builders Attention: Energy and Home Environment

15th \& M. Streets N.W. Washington, D.C. 20005

National Concrete Mnsongy Ascociation

Attention: Energy Engineer

2302 Horse Pen Raad

Herndon, Va. 22070

Brick Inntitute of America Attention: Energy Englneer 11490 Commerce Park Drtve Suite 300

Reston, Va. 22091

National Renewable Energy Laboratory Atterition: Solar Bulldings Program 1617 Cole Boulevard

Colden. Co. 80401

Solar Eneres Induntries Arsociation

777 N. Capitol Street, NE \#805

Washington, DC 20002

National Appropriate Technology

Assistance Serolice

P.O. Box 2525

Butte, MT 59702

1-800-428-2525

ESEC

300 Street, Road 401

Cape Canavral, FL 32920

Passive Solar Induntries Council 1090 Vermont Avenue, Sulte 1200 Washington, DC 20005 


\section{Example Tables}

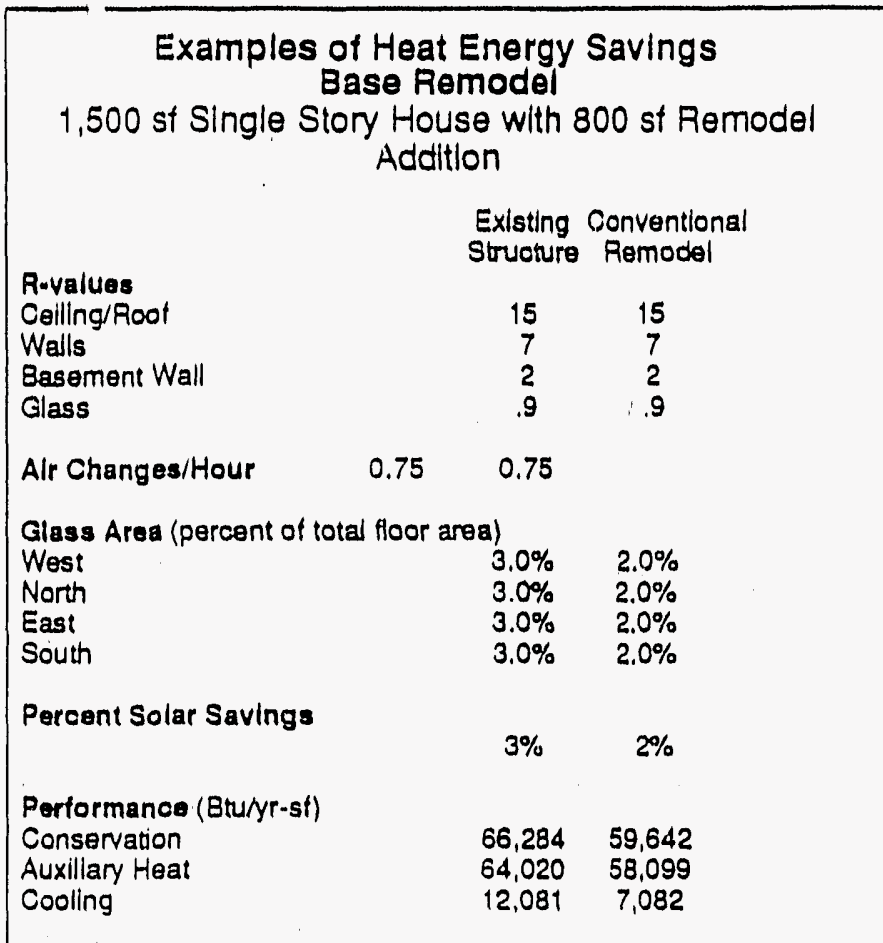

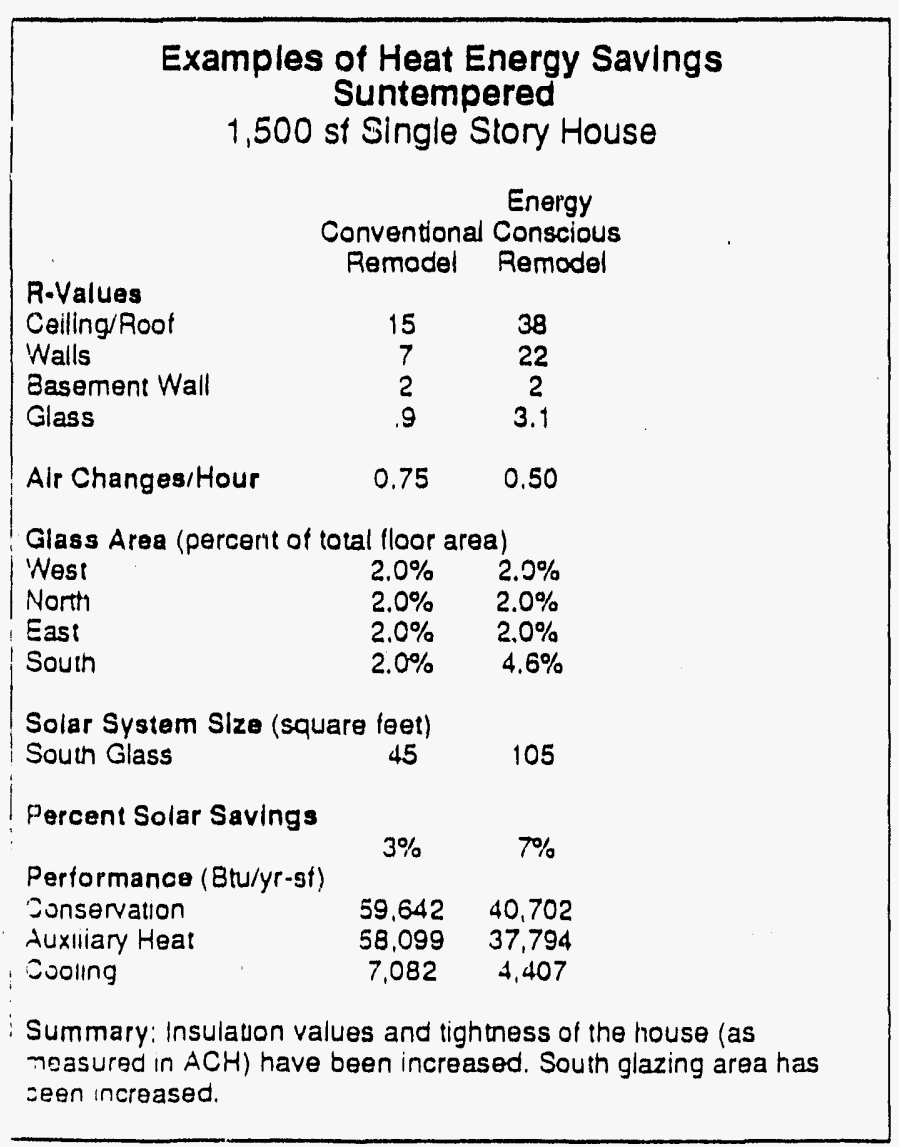

\begin{tabular}{|c|c|c|}
\hline \multicolumn{3}{|c|}{$\begin{array}{c}\text { Examples of Heat Energy Savings } \\
\text { Passive Solar-Direct Gain } \\
1,500 \text { st Single Story House with } 800 \text { si Addition }\end{array}$} \\
\hline & $\begin{array}{l}\text { Convention } \\
\text { Remodel }\end{array}$ & $\begin{array}{l}\text { Energy } \\
\text { Conscious } \\
\text { Remodel }\end{array}$ \\
\hline $\begin{array}{l}\text { R-values } \\
\text { Celling/Root } \\
\text { Walls } \\
\text { Plasement Wall } \\
\text { Glass }\end{array}$ & $\begin{array}{r}15 \\
7 \\
2 \\
9\end{array}$ & $\begin{array}{c}38 \\
22 \\
2 \\
3.1\end{array}$ \\
\hline Alr Changes/Hour & 0.75 & 0.50 \\
\hline $\begin{array}{l}\text { Glass Area (percent of } \\
\text { West } \\
\text { North } \\
\text { East } \\
\text { South }\end{array}$ & $\begin{array}{c}\text { total floor ar } \\
2.0 \% \\
2.0 \% \\
2.0 \% \\
2.0 \%\end{array}$ & $\begin{array}{l}2.0 \% \\
2.0 \% \\
2.0 \% \\
6.3 \%\end{array}$ \\
\hline $\begin{array}{l}\text { Added Thermal Mass } \\
\text { Percent of Floo: Area }\end{array}$ & $0.0 \%$ & $11.5 \%$ \\
\hline $\begin{array}{l}\text { Solar System Size (sq } \\
\text { South Glass } \\
\text { Added Thermal Mass }\end{array}$ & $\begin{array}{c}\text { vare (eet) } \\
45 \\
0\end{array}$ & $\begin{array}{l}145 \\
264\end{array}$ \\
\hline Percent Solar Savings & $3 \%$ & $9 \%$ \\
\hline $\begin{array}{l}\text { Performanoa (Btu/yr-s) } \\
\text { Conservation } \\
\text { Auxillary Heat } \\
\text { Coolling }\end{array}$ & $\begin{array}{c}59,642 \\
58,099 \\
7,082\end{array}$ & $\begin{array}{c}40,595 \\
36,838 \\
3,200\end{array}$ \\
\hline $\begin{array}{l}\text { Summary: Insulation ar } \\
\text { facing glazing has been } \\
\text { examples, added mass } \\
\text { south glass area. }\end{array}$ & $\begin{array}{l}\text { nd tightness } \\
\text { substantlall } \\
\text { area is assu }\end{array}$ & $\begin{array}{l}\text { have been increased. South- } \\
\text { increased. For these } \\
\text { med to be six times the added }\end{array}$ \\
\hline
\end{tabular}




\begin{tabular}{|c|c|c|}
\hline \multicolumn{3}{|c|}{$\begin{array}{c}\text { Examples of Heat Energy Savings } \\
\text { Passive Solar-Sunspace } \\
1,500 \text { st Single Story House with } 800 \text { sf Addition }\end{array}$} \\
\hline \multicolumn{3}{|c|}{$\begin{array}{cl} & \text { Energy } \\
\text { Conventional Conscious } \\
\text { Remodel Remodel }\end{array}$} \\
\hline $\begin{array}{l}\text { R-Values } \\
\text { Ceiling'Roof } \\
\text { Walls } \\
\text { Basement Wall } \\
\text { Glass }\end{array}$ & $\begin{array}{r}15 \\
7 \\
2 \\
9\end{array}$ & $\begin{array}{l}38 \\
22 \\
2 \\
3.1\end{array}$ \\
\hline Alr ChangesiHour & 0.75 & 0.50 \\
\hline $\begin{array}{l}\text { Glass Area (pursent of tot } \\
\text { West } \\
\text { North } \\
\text { East } \\
\text { South (windows) } \\
\text { Sunspaca }\end{array}$ & $\begin{array}{l}\text { tal floor ar } \\
2.0 \% \\
2.0 \% \\
2.0 \% \\
2.0 \% \\
0.0 \%\end{array}$ & $\begin{array}{l}\text { ea) } \\
2.0 \% \\
2.0 \% \\
2.0 \% \\
2.0 \% \\
4.3 \%\end{array}$ \\
\hline $\begin{array}{l}\text { Solar System Slze (squar } \\
\text { South Glass } \\
\text { Sunspace Glass } \\
\text { Sunspaco Thermal Mass }\end{array}$ & $\begin{array}{c}\text { (eet) } \\
45 \\
0 \\
j\end{array}$ & $\begin{array}{c}45 \\
100 \\
300\end{array}$ \\
\hline Percent Solar Savings & $3 \%$ & $10 \%$ \\
\hline $\begin{array}{l}\text { Pertormance (Btu/yr-sf) } \\
\text { Conservauon } \\
\text { Auxiliary Heat } \\
\text { Cocling }\end{array}$ & $\begin{array}{c}59,642 \\
58,099 \\
7,082\end{array}$ & $\begin{array}{r}40,595 \\
36.556 \\
2,771\end{array}$ \\
\hline \multicolumn{3}{|c|}{$\begin{array}{l}\text { Summary: Insulation and tightness have been increased. The } \\
\text { sunspace assumed here is semi-enclosed (surrounded on three } \\
\text { sices by conoitioned rooms of the house, as in Figure SSC } 1 \text { of the } \\
\text { worksheets), with vertical south glazing. The common wall is a } \\
\text { thermal mass wall made of masonry. Sunspace glazing is } \\
\text { assumed to be double. }\end{array}$} \\
\hline
\end{tabular}

\begin{tabular}{|c|c|c|}
\hline \multicolumn{3}{|c|}{$\begin{array}{c}\text { Examples of Heat Energy Savings } \\
\text { Passive Solar-Thermal Storage Wall } \\
1,500 \text { st Single Story House with } 800 \text { si Addition }\end{array}$} \\
\hline \multicolumn{3}{|c|}{$\begin{array}{cc} & \text { Energy } \\
\text { Conventional Conscious } \\
\text { Remodel Remodel }\end{array}$} \\
\hline \multicolumn{3}{|l|}{ R-Values } \\
\hline $\begin{array}{l}\text { Coiling/Roof } \\
\text { Walls }\end{array}$ & $\begin{array}{r}15 \\
7\end{array}$ & $\begin{array}{l}38 \\
22\end{array}$ \\
\hline Basement Wall & 2 & 2 \\
\hline Glass & 9 & 3.1 \\
\hline Alr Changes/Hour & 0.75 & 0.50 \\
\hline \multicolumn{3}{|c|}{ Glass Area (percent of total floor area) } \\
\hline West & $2.0 \%$ & $2.0 \%$ \\
\hline North & $2.0 \%$ & $2.0 \%$ \\
\hline East & $2.0 \%$ & $2.0 \%$ \\
\hline South & $2.0 \%$ & $2.0 \%$ \\
\hline Thermal Storage Wall & $0.0 \%$ & $4.3 \%$ \\
\hline \multicolumn{3}{|c|}{ Solar System Slze (square feet) } \\
\hline South Glass & & 0 \\
\hline Thermal Storage Wall & 0 & 100 \\
\hline \multicolumn{3}{|l|}{ Percent Solar Savings } \\
\hline & $3 \%$ & $11 \%$ \\
\hline \multicolumn{3}{|l|}{ Performance (Btu/yr-sf) } \\
\hline $\begin{array}{l}\text { Conservation } \\
\text { Auxiliary Heat } \\
\text { Cooling }\end{array}$ & $\begin{array}{r}59,642 \\
58,099 \\
7,082\end{array}$ & $\begin{array}{r}40,595 \\
35,844 \\
1,860\end{array}$ \\
\hline \multicolumn{3}{|c|}{$\begin{array}{l}\text { Summary: In the case of a Thermal Storage Wall, south-facing } \\
\text { glazing and thermal mass are incorporated together. The estimates } \\
\text { here assume a } 12 \text {-inch thick concrete Thermal Storage Wall with a } \\
\text { selective surtace and single glazing. }\end{array}$} \\
\hline
\end{tabular}

\begin{tabular}{|c|c|c|}
\hline \multicolumn{3}{|c|}{$\begin{array}{l}\text { Cooling Potential } \\
\text { Existing Structure } 12,081 \text { Btu/yr-st }\end{array}$} \\
\hline Strategy & $\begin{array}{l}\text { Energy } \\
\text { Savings } \\
\text { (Btwyr-si) }\end{array}$ & $\begin{array}{l}\text { Percent } \\
\text { Savings }\end{array}$ \\
\hline $\begin{array}{l}\text { No Night Ventilation } \\
\text { without coiling lans } \\
\text { with coiling tans }\end{array}$ & $\begin{array}{c}0 \\
2,820\end{array}$ & $\begin{array}{l}0 \% \\
23\end{array}$ \\
\hline $\begin{array}{l}\text { Night Ventilation } \\
\text { without coiling lans } \\
\text { with cailing fans }\end{array}$ & $\begin{array}{l}2.200 \\
4.480\end{array}$ & $\begin{array}{l}18 \\
37\end{array}$ \\
\hline $\begin{array}{l}\text { High Mass }{ }^{2} \\
\text { without ceiling lans } \\
\text { with celling tans }\end{array}$ & $\begin{array}{l}+10 \\
300\end{array}$ & $\frac{1}{2}$ \\
\hline \multicolumn{3}{|c|}{$\begin{array}{l}1 \text { With nignt ventlaucn, :he nouse is ventlatec at night wnen } \\
\text { :emperature and humidity concitions are iavciacle. }\end{array}$} \\
\hline $\begin{array}{l}2 \text { A "high mass" } \\
\text { least equal io the }\end{array}$ & $\begin{array}{l}\text { with a therm } \\
\text { area. }\end{array}$ & iss area at \\
\hline
\end{tabular}




\section{Technical Basis for the Builder Guidelines}

\section{How the Builder Guidelines Were Produced}

The text of the Bullder Guddelines book is generated by merging two computer iles. The first is a word-processor tile containing the text: it does not change from location to location. The second contains numbers and text and is location dependent This second ille is produced by running a computer program that calculates performance numbers based on long-term monthly weather and solar data complled by the National Oceanic and Atmospherlc Administration for a particular location. The merge operation slots the numbers and text in the second flle into their correct locations in the first fle. This is then laser printed to produce the camera-ready manuscript.

\section{More than a Decade of Experience}

The concentrated effort of research, design, construction, monitoring, and evaluation of actual bulldings that started at the First Passive Solar Conference in Albuquerque in 1976 has continued up to the present. It is estimated that more than 200,000 passive solar homes have been built in the United States during this time. This wealth of experience has been reviewed by NREL. the Technical Committee of PSIC, and by the Standing Committee on Energy of the National Association of Home Builders and is disulled into these Guidelines.

\section{Analysis Procedures}

The analysis procedures used throughout the Guidelines were developed using simple, well-established methods for estimating the performance of passive solar heatng and natural cooling strategles. These procedures (described below) were developed at the
Los Alamos National Laboratory with funding from the U.S. Department of Energy Solar Buildings Program. See the references for more iniormation.

\section{Annual Heat Loss (Worksheet I)}

The heat-loss calculation is based on a straightforward summation of the traditional elements that make up the bullding heat-loss coefficient (excluding the solar components). The worksheet procedure estimates the annual heat loss by multplying the heat-loss coefficient by annual degree days (tumes 24 to convert from days to hours). Degree days for each month were determined using an appropriate base temperature that accounts for an assumed thermostat setting of 70 degrees, an assumed internal heat generation of $36 \mathrm{Btu} /$ day per sq ft of floor area, and the total bullding loss coefficient. This forms the basis of the table of heating degree day multipliers. The result of the worksheet is an estumate of the annual heat required to maintain comfort, excluding both positive and negative effects resulting from the solar components. in this estumate, no solar heating credit is given to east, west, and north windows, because it is assumed that these will be protected by vegetation or other shading in accordance with the Bullder Guideline recommendations. This is a conservative assumption because there will always be some solar gain through these windows.

\section{Annual Auxiliary Heat (Worksheet II)}

The tables of passive solar savings fractions are calculated using the solar load ratio (SLR) method (references 1 and 2). Monthly solar savings fractlon (SSF) values are determined using correlation fits to the results of hourly computer simulation calculations for a variety of climates. These 12 values are converted into an annual value and entered into worksheet Tables Fl-F4. The SLR method gives answers that agree within about $5 \%$ of the hourly computer simulations and within $11 \%$ of the measured passive solar performance of 55 buildings monitored under the Solar Bulldings Program. The SSF estimates account properly for both solar galns and heat losses through the solar aperture and, thus, correct for omitting the solar components from the calculation of annual heat luss.

\section{Temperature Swing (Worksheet III)}

The temperature swing estimate on worksheet III is based on the diumal heat capacity (dhc) method (reference 3 ). The method is an analytic procedure in which the total heat stored in the building during one day is estimated by summing the effective heat storage potental of the all the various materials in the building for a 24-hour periodic cycle of solar input. Rooms with direct gain are assumed to have radiative coupling of the solar heat to the mass. Rooms connected to rooms with direct gain are assumed to have convective coupling, which is rather less effective, especialiy for massive elunents. The dho of the sneetrock, framing, and fumiture is approximated as 4.5 or $4.7 \mathrm{Btu} /{ }^{\circ} \mathrm{F}$ per sq ft of floor area. Worksheet Tables $\mathrm{H} 1$ and $\mathrm{H} 2$ list the increased value of diumal heat capacity for various conventional materials that are oiten used to provide extra heat storage. assuming these materials replace sheetrock 
The only numbers in worksheet III that are location dependent are the comfort factors, taken from Table 1 . The direct-gain comfort factor is $61 \%$ of the solar gain transmitted through vertical. south-facing double glazing on a clear January day. The driving effect of sunspaces and vented Trombe walls is assumed to result in one-third this value, based on data from monitored buildings. The origin of the $61 \%$ factor is described in the references.

\section{Annual Auxiliary Cooling (Worksheet $\mathrm{IV}$ )}

The purpose of including the summer cooling entumates in the Builder Guidelines is to (1) determine if design elements added to promote passive solar heating will cause excessive summer cooling loads and (2) provide a rough estimate of the effectiveness of solar shading and natural cooling strategles. The analysis method is based on a modified monthly degree-day procedure in which the day is divided into day and night periods (reference 4). All estimates are dertved from correlations based on hourly computer simulations. Solar, conduction, and Internal gains are estumated for each half-day period in each month. Delay factors are used to account for heat carryover from day to night and night to day. The results are estimates of annual sensible cooling delivered by the air conditioner and do tot include latent loads.

Because the the original Los Alamos monthly procedure is too complex to be implemented in a worksheet, a simplified procedure is adopted on worksheet IV. Heat Gain Factors and Internal Gain Factors in Tables $L$ and $N$ are the rivulated annual incremental cooling loads resulting from a one-unit incremental change in the respective heat input parameter (that is, a one-unit change in UA, glazing area, or number of bedrooms). The combined heat load resulting from all inputs is summed and then adjusted for thermal mass and venulation. This correction includes a constant required to match the calculated cooling load of the existing building. This linearlsed procedure gives accurate estimates for cooling loads that are less than about $150 \%$ of the exdsung building; however, it underestimates very large cooling loads in poorty designed bulldings.

The adjustment factors for ventilation properly account for maintaining comfort in hot and humid climates. Vertllation is restricted to tumes when the outside dew-point temperature is less than $62^{\circ} \mathrm{F}$. This restriction avoids ventllation when high humidity might cause discomfort.

\section{Not for Sizing Equipment}

All heating and cooling values given in the Builder Guidelines Tables and numbers calculated using the worksheets are for annual heat delivered or removed by the mechanical heating or cooling system. You cannot directly use these numbers for sizing the capactiy of this equipment. The methods developed by the American Soclety of Heating, Refrigerating, and Alr Conditioning Engineers for sizing equipment are wellestablished and are recommended. You may wish, however, to supply a copy of the design worksheets to the mechanical contractor so they can learn what Rvalues and glass areas are specifled. This will allow them to more accurately size the equ'inment to be used. The purpose of the guldance provided in these booklets is to minimize the opurating time and resources consumed by this equipment.

\section{Using the Worksheets in Nearby Locations}

The applicability of worksheets I and II can be extended somewhat by using the base- $65 \cdot F$ degree-day value for a site which is close to the location for which the worksheet tables were generated. We recommend limiting such applications to sites where the annual heating degreedays are within plus or minus $10 \%$ of the parent location and where it is reasonable to assume that the solar radiation is about the same as in the parent location. The procedure is simple: Use the measured base- $65^{\circ} \mathrm{F}$ degree-day value in worksheet I, line F, instead of the degree-day value for the parent location.

Worksheet III depends unly slight'y on location. The only variables are the Comfort Factors in Table 1, which only change with lautude. Thus, this worksheet can be used anywhere within 4 degrees of latitude of the parent location.

The coolling estumate obtained from worksheet IV is specific to the location. Within the same vicinity and within plus or minus $20 \%$, the result could be adjusted, based on a ratlo of coolling degree days. However, this adjustment is not done automatically within the worksheet.

\section{Getting Data}

Heating and cooling degree-day data can be obtained from the National Climatic Center, Asheville, NC. Refer to Climatography of the United States No. 81 which lists monthly normals for the pertod $1951-1980$ on a state-by-state basis. More than 2400 locations are listed in this data base. 


\section{References}

1. J. Douglas Balcomb, Robert W. Jones, Robert D. McFarland, and Willlam O. Wray, "Expanding the SLR Method", Passive Solar Journal, Vol. 1, No. 2, 1982. pp. 67-90. Avallable from the American Solar Energy Society, 2400 Central Ave. Unit B-1, Boulder, CO 80301.

2. J. Douglas Balcomb, Robert W. Jones, Robert D. McFarland, and William $O$. Wray, Passive Solar Eleating Analyais, American Society of Heating. Refrigerating, and Alr-Conditioning Engineers, 1984. Avallable from ASHRAE, 1719 Tullie Circle, NE, Atlanta, GA 30329.

3. J. Douglas Balcomb and William O. Wray, Paseive Solur Eleating Analynis, Supplement One, Thermal Mines iffects and Additional sLR Correlations, American Society of Heating, Refrigerating, and Air Conditioning Engineers, 1987. See ASHRAE address above.

4. Robert D. McFarland and Glorla Lazarus, Monthly Aurillary Coollng Eatimation for Reaidential Buildings, LA-11394-MS, Los Alamos National Laboratory, Los Alamos, NM 87545, 1989.

5. J. Douglas Balcomb and Alexander B. Lekov, Algorithms for Builder Guidelines, SEKI/TP-254-3492, National Renewable Energy Laboratory, Golden $\mathrm{CO}$. Also contained in the Proceedings of the 14th Passive Solar Conference, Denver, June 19-23, 1989. See ASES address abnve. 


\section{Example}

Passive Solar Design Strategles

PSIC's Guldelines for Bullders

Passive Solar Industries Council

U. S. Department of Energy Solar Butldings Program

Solar Energy Research Institute Los Alamos National Laboratory Charles Eley Assoctates 


\section{Introduction}

\section{Purpose}

The purpose of this document is to explain how to use the passtve solar worksheets avallable from the Passive Solar Industries Councll. Separate Worksheets booklets are avallable for specific locations throughout the continental USA. Each booklet contains detalled technical data for a specific location. Although the example presented in this booklet is for a moderate midAtlantic climate, the procedure is presented in a general manner and is intended to be used for all locations.

In addition to the

Worksheets booklets and this Example booklet, Guddelines booklets for specific locations are also avallable from the Passtve Solar Industries Counctl.

\section{General Description of Worksheets}

The Worksheets booklet for each location provides an easy-to-use calculation procedure, allowing the designer to estimate the performance level of a particular bullding design and compare it against a base-case performance level or against the performance of the bullder's more conventional house.
A separate worksheet is provided for each of four separate performance levels performance level and associated target. These are described below:

Worksheet I: Conservation Performance Level: the estumated heat energy needed by the bullding each year from both the solar and auxdllary heating systems. The units are Btu/yr-sf.

Worksheet II: Auxillary Heat Performance Level: the estimated heat that must be provided each year by the auxdliary heating system. This worksheet accounts for the solar savings. The units are Btu/yr-sf.

Worksheet III: Thermal Mass/Comfort: the temperature swing expected on a clear winter day with the auxdllary heating system not operating. The units are ${ }^{\circ} \mathrm{F}$.

Worksheet IV: Summer Cooling Performance Level: the estimated annual cooling load of the bullding. The units are Btu/yr-sf.
The estimates from

Worksheets I and II are based on a heating thermostat setting of $70^{\circ} \mathrm{F}$. The estimates from Worksheet IV are based on a cooling thermostat setting of $78^{\circ} \mathrm{F}$ with no celling fans and $82^{\circ} \mathrm{F}$ with ceilling fans.

The worksheets are supported by a number of data tables. The data tables are given a letter designation and are referenced when applicable next to each worksheet entry.

A description and drawings of the example bullding are provided below, followed by completed worksheets. Data tables have also been included when approprate.

Each step of the worksheets is then explained in detall. 
Description of Example Bullding

A 1,504 square foot passive solar, single-familly home is used to lllustrate how to use the worksheets. A floor plan. bullding elevations, bullding sections and detalls are shown below.
The bullding has an attached sunspace. The sunspace floor has a four-inch thick slab-ongrade with quarry tile set in a mortar bed. The sunspace is separated from the conditioned portion of the house by sliding gllass doors and a masonry ireplace wall. Awning windows located at the top and bottom of the south wall provide outside ventllation for the sunspace.
South facing windows provide direct gain solar heating to the dining area, ktchen and master bedroom. The south glazing in the kdtchen and dining area provides heat to an exposed slab-on-grade.

The east portion of the house is slab-on-grade construction. The great room and master bedroom suite are ratsed floor construction. The slab-on-grade floor in the ldtchen and dining area is finished with ceramic tle so that the floor may function as thermal mass.

The exterlor doors are metal with a foam core center.

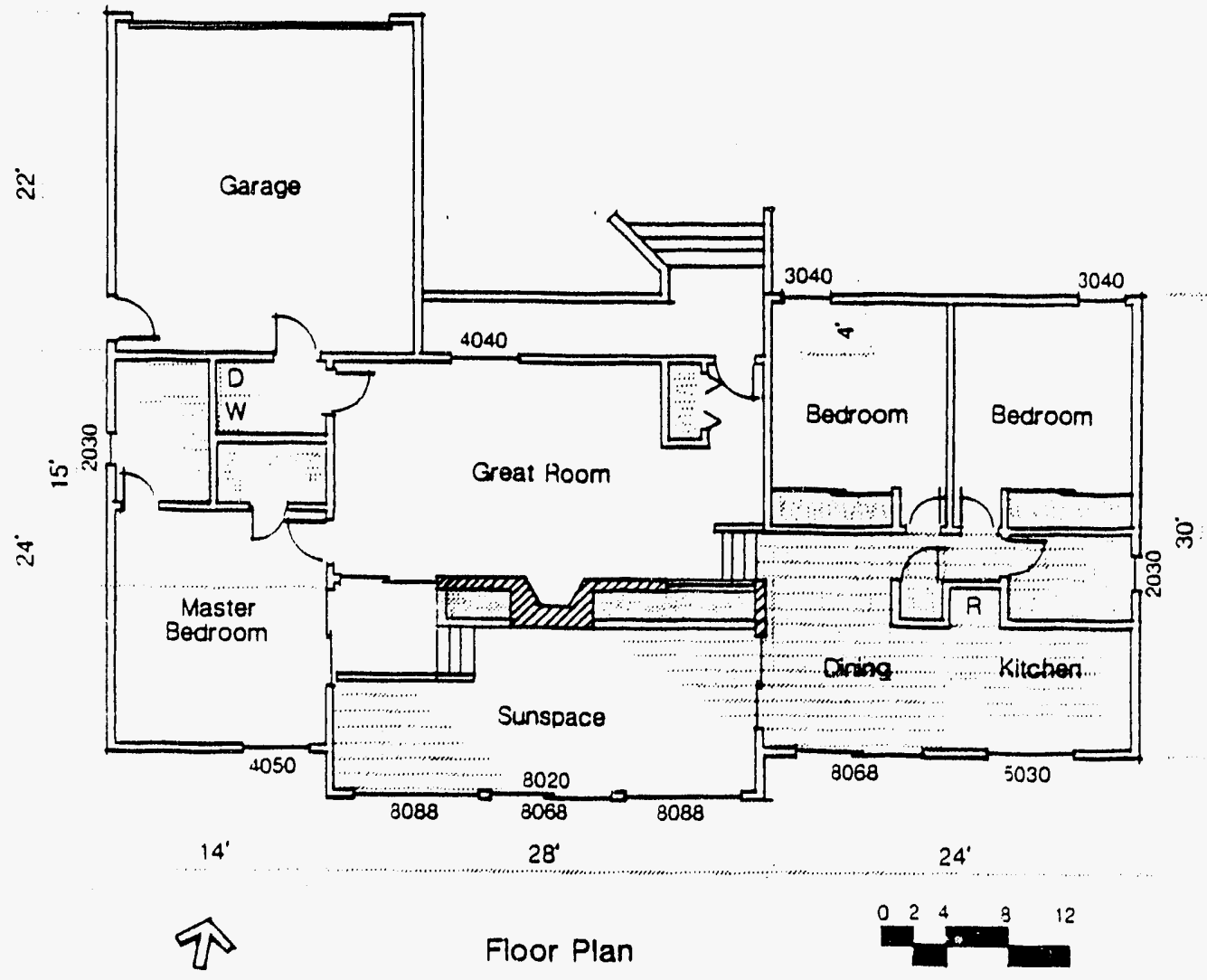




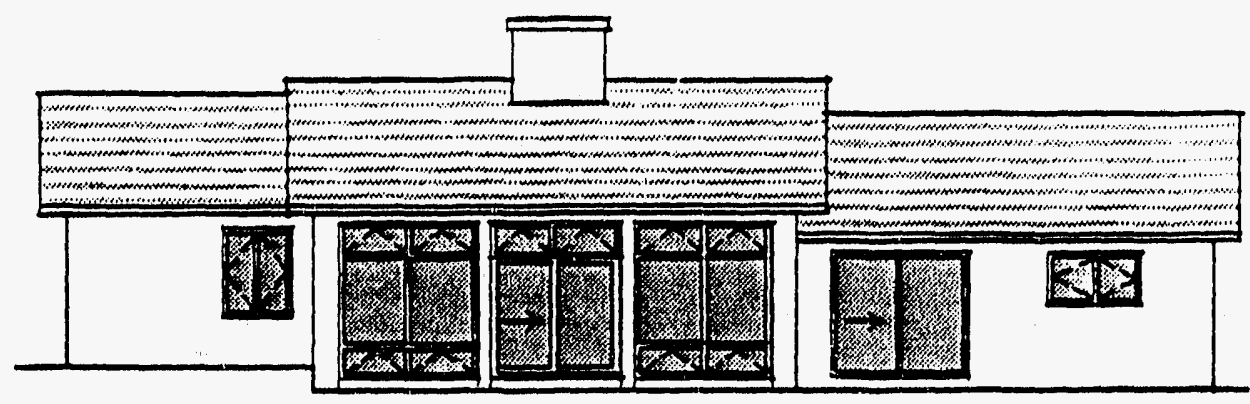

South Elevation

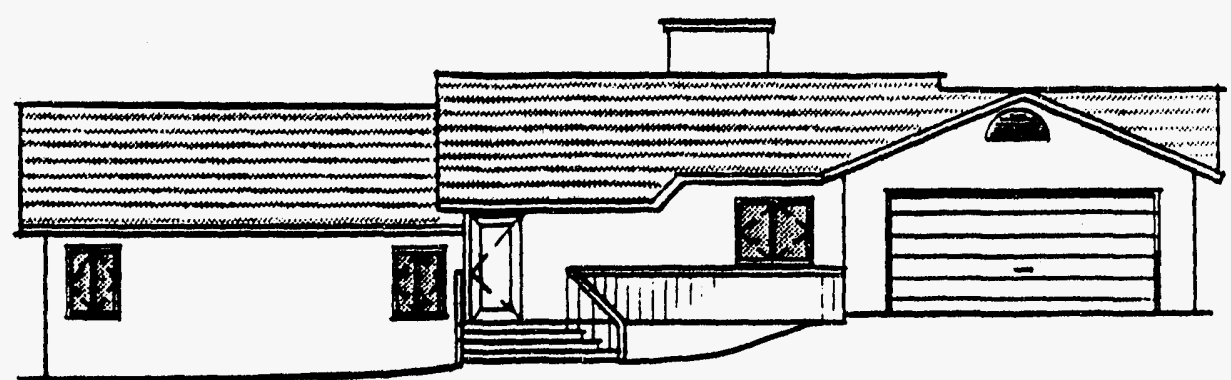

North Elevation

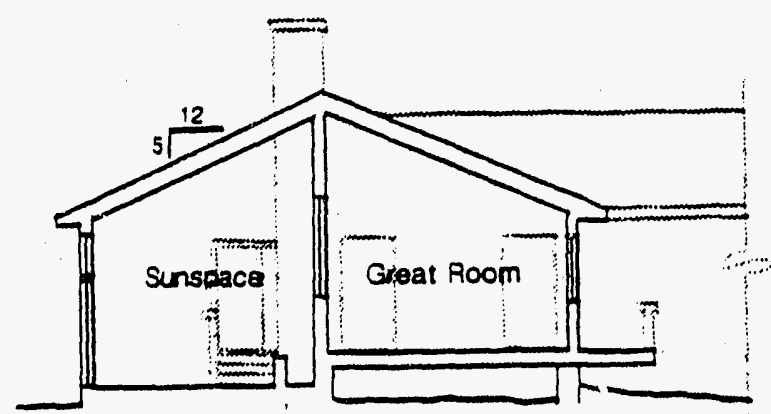

Section
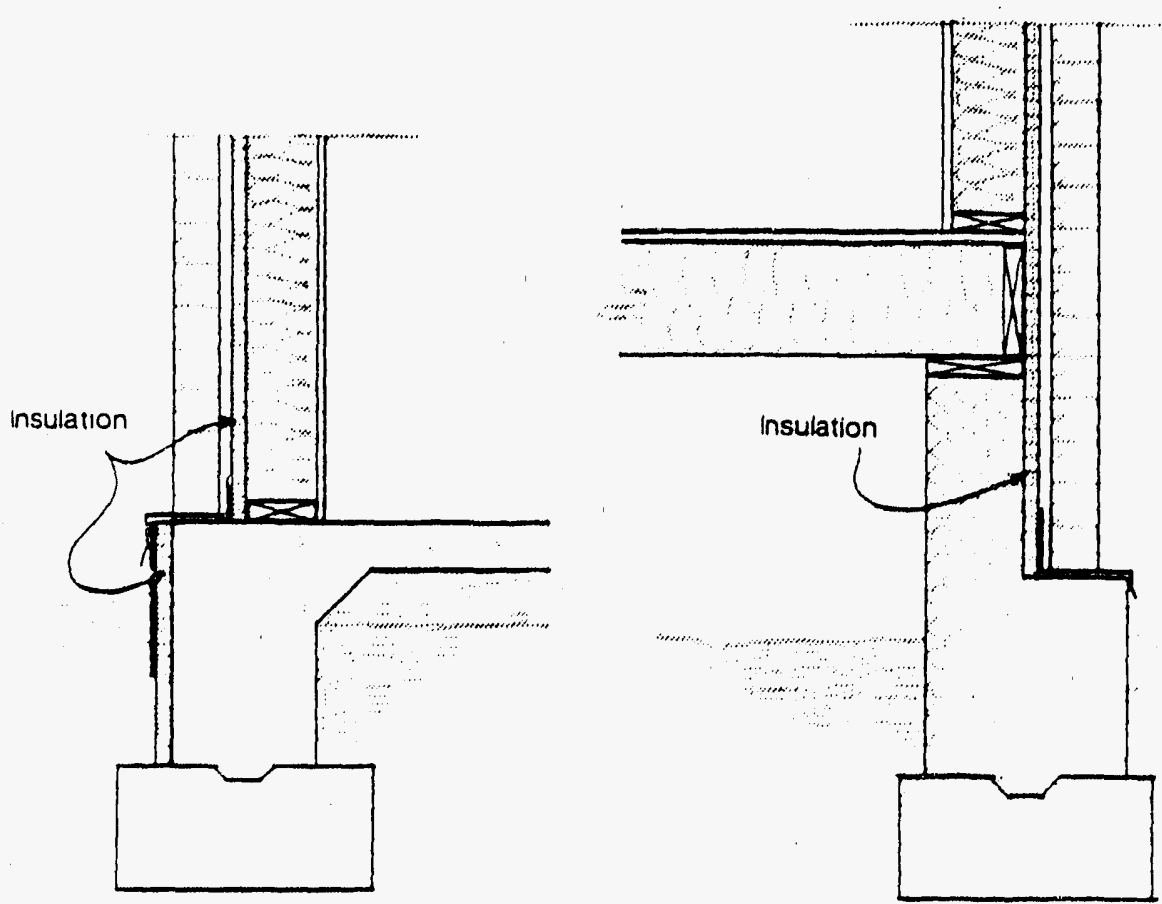
General Project Information

Proiec Name EXAMPLE BUILDINt

Location ANYTONA, ULSA

Designer

Poor Ares 1504 si

Dare

Worksheet I: Conservation Performance Level

A. Earelope Heat Loss

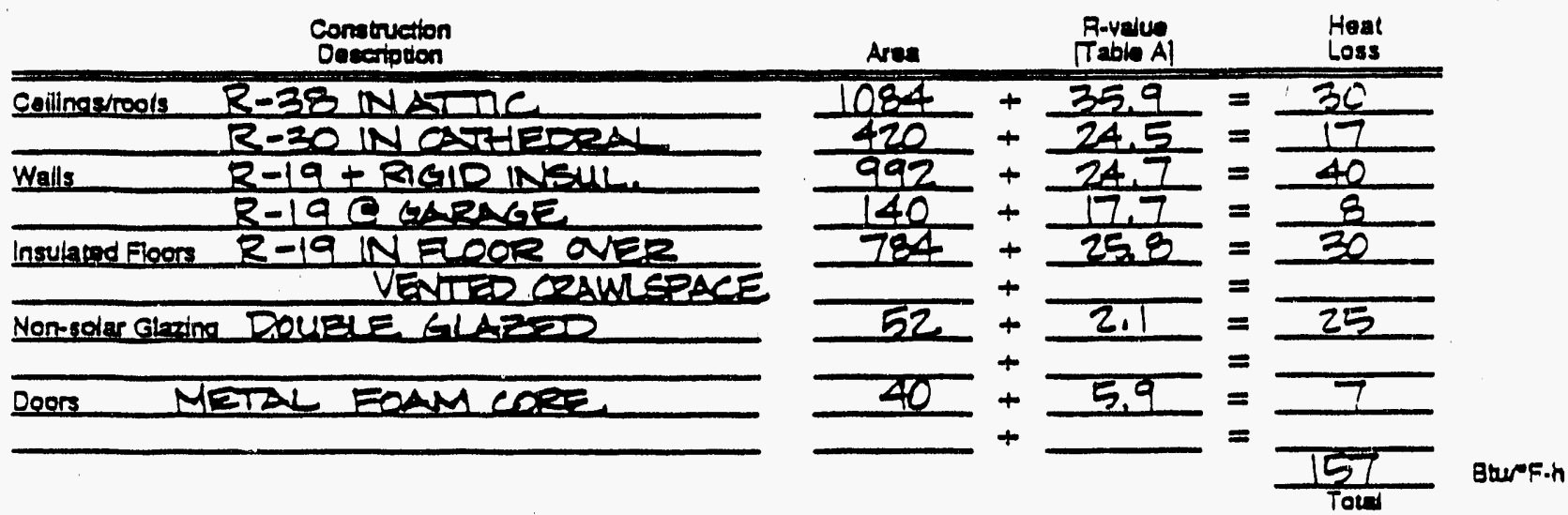

B. Foundation Perimeter Beat Loss

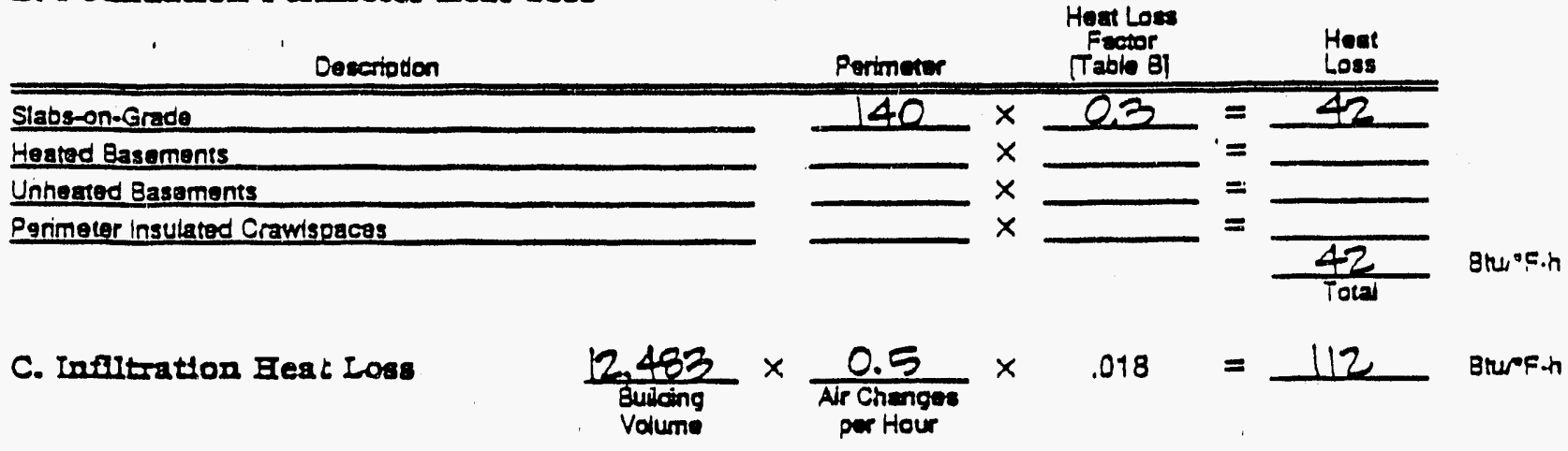

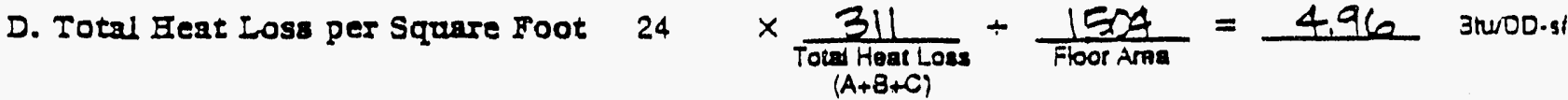

E. Conserpation Performance Level

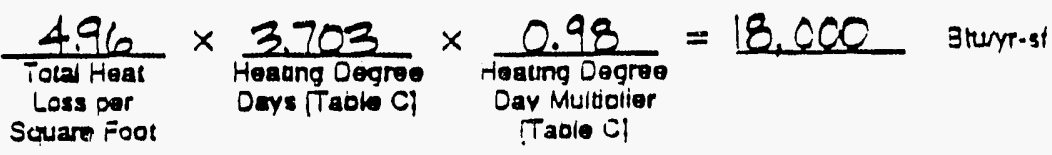

F. Comparison Conservation Performance (From Promous Cavalation or trom Table o)

25,380 irurr.s:

Compare Llne E, to Ldne F 


\section{Worksheet I: \\ Conservation Performance Level}

Worksheet I is essentially a heat loss calculation, simular to the type of calculation made to size heating and coollng equipment. The major difference is that the calculation does not consider heat loss through any of the passtve solar systems. The following bullding components in the example bullding are not considered in the calculation:

- Heat loss through drect gain solar glazing.

- Heat loss through walls and windows that separate the house from the sunspace.

If the example bullding had Trombe walls or water walls, heat loss through these passive solar systems would also be excluded from the calculation.

Heat loss from the passive solar systems is excluded since the solar savings fractions in Worksheet II take these losses into account.
Step A. Envelope Heat Loss

The first step is to calculate the heat loss through the bullding envelope. The bullding envelope consists of all walls, roofs, floors, non-solar windows and doors that enclose the condittoned space of the house.

Heat loss for each envelope component is calculated by dividing the surface area of the component by the total R-value. The total envelope heat loss is the sum of the heat loss for all of the envelope components.

Table A in the Worksheets booklet contains $R$-values that may be used in the calculation. There are actually five separate tables labeled A1, A2, A3, A4 and $A 5$. A separate table is provided for cellings/roofs, walls, floors, winclows and doors. The R-values in these tables include the thermal resistance of both the insulation and other materials that typically make up the construction assembly such as exterlor sheathing and sheetrock. They also account for framing members that penetrate the insulation and reduce the effecttveness.
Cellings / Roofs

There are two types of celling/roof construction in the example bullding. R-38 mineral insulation is located in an attic space, and R-30 insulation is located in the framed cathedral celling. The total R-value is selected from Table Al for each celling/roof component. The values in Table A1 account for the buffering effect of the attic (when applicable), the celling materlal (sheetrock) and the effect of framing.

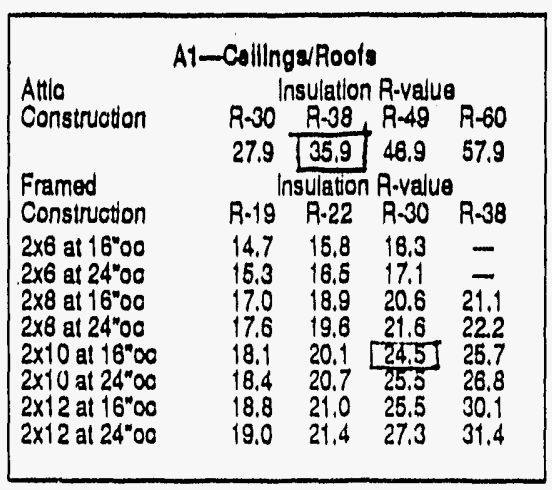

The area and $R$-value of the two different types of construction are entered on two lines of the table under "cellings/roofs" and the heat loss is calculated by dividing the surface area by the total R-value. Note that the celling over the sunspace is not included in this calculation. 


\section{Walls}

There are two types of wall construction in the example bullding. The typical exterlor wall is of $2 \times 6$ wood frame construction with R-19 mineral insulation in the cavity, An Insulating sheathing with an R-7 rating is attached to the exterior surface of the framing. The wall is finished with $1 / 2$ inch sheetrock on the inside and a brick veneer on the outside.

The second type of wall construction separates the house from the garage. This wall is also of $2 \times 6$ wood frame construction with R-19 in the cavity, but it does not have the insulating sheathing or the brick veneer. Note that the walls that separate the house from the sunspace are not included.

It is necessary to measure the surface area of each type of wall construction. The surface area may be determined by multiplying the length of wall by the average height and subtracting the area of doors and windows.
The R-value of each wall type is determined from Table A2 in the Worksheets booklet. The R-value of both wall types is 17.7 from the table, but since the first wall type has R-7 insulating sheathing, this is added to the value from the table so that 24.7 is used in the calculations. These $R$-values along with the associated areas are entered on two lines of the table and the heat loss is calculated by dtwding each surface area by the corresponding R-value.

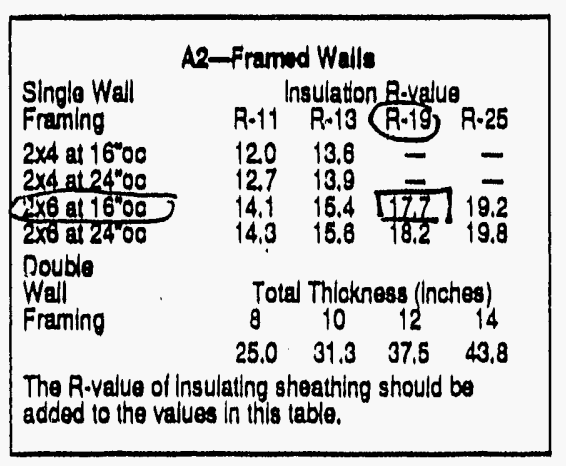

\section{Floors}

Only the raised floor is considered in this step of the heat loss calculation; heat loss from the slab-on-grade floor is considered in Step B. There is one type of ratsed floor construction in the example bullding. R-19 mineral insulation is placed between $2 \times 10$ floor joists at 16 inches on center; the crawlspace beneath is ventllated.
The total R-value is selected from Table A3, which considers the buffering effect of the crawlspace as well as framing and the floor materials. The area and $R$-value is entered on one line of the table and the heat loss is calculated by dividing the area by the R-value.

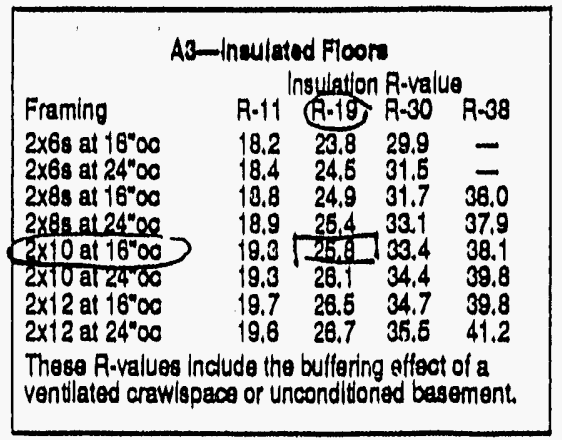

Had there been different insulation conditions for the radsed floor, an additional line of the table would be completed for each condition.

If the example bullding had insulated floors over a garage or unheated basement, these components would also be included in this step.

As an alternative to insulating between the floor joists, the perimeter walls of the crawlspace could have been insulated and floor insulation eliminated. When this technique is used, the perimeter heat loss method in Step B should be used. Step A only includes floors when insulation is placed in the floor assembly. 


\section{Non-solar Glazing}

Next, heat loss from the nonsolar glazing is calculated. Note that the passive solar direct gain glazing is not included. Also the windows that separate the house from the sunspace are nixc included.

The rough frame opening of each window is generally used for the window area. This is because the $R$-values presented in Table A4 and most heat loss data presented by window manufacturers is for the rough frame opening. Using the rough frame opening also makes it easter to estimate window areas since windows are usually spectfled on the plans in terms of the rough frame dimensions.

\begin{tabular}{|c|c|c|c|}
\hline \multicolumn{4}{|c|}{ A-WIndowe } \\
\hline & $\begin{array}{l}\text { Wood } \\
\text { Frame }\end{array}$ & $\begin{array}{c}\text { Slandard } \\
\text { Metal y } \\
\text { Frame }\end{array}$ & $\begin{array}{l}\text { Matal } \\
\text { Frame } \\
\text { W/ Thermal } \\
\text { Break }\end{array}$ \\
\hline \multicolumn{4}{|c|}{ 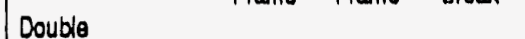 } \\
\hline $\begin{array}{l}1 / 4^{*} \text { space } \\
1 / 2 * \text { space } \\
\text { Low-e }\end{array}$ & $\frac{1.8}{\frac{2.1}{3.1}}$ & $\begin{array}{l}1.4 \\
1.6 \\
2.2\end{array}$ & $\begin{array}{l}1.5 \\
1.8 \\
3.0\end{array}$ \\
\hline $\begin{array}{l}\text { Triple } \\
\text { 1/4" space } \\
1 / 2 " \text { specos }\end{array}$ & $\begin{array}{l}2.7 \\
3.3\end{array}$ & $\begin{array}{l}1.8 \\
22\end{array}$ & $\begin{array}{l}2.1 \\
2.7\end{array}$ \\
\hline \multicolumn{4}{|c|}{$\begin{array}{l}\text { These R-values are for the entire rough framed } \\
\text { window opening. When stom sash is addod, an } \\
\text { additional } 11 \text { may bo added. One hall the R-value } \\
\text { of moveable insulation may also be addod, when } \\
\text { appropriate. }\end{array}$} \\
\hline
\end{tabular}

Windows in the example bullding are all double-pane wood windows with a $1 / 2$ inch air space between the panes. The R-value for this window type is 2.1, selected from Table A4.

The non-solar window area is taken from the bullding plans. These values are entered in the table and the heat loss is calculated by dividing the window area by the window $R$-value. If the example bullding had more than one window type (different R-values), then additional lines of the table would be completed.

\section{Doors}

The doors are the last component of the envelope to consider. The example bullding has two exterfor doors: the maln entrance and an additional door to the garage. These have a total surface area of 40 square feet and an $R$-value is selected from Table A5. Note that the door that separates the garage from the exterior is not included since the garage is unconditioned.

\begin{tabular}{|c|c|}
\hline \multicolumn{2}{|c|}{ A5-Doors } \\
\hline Sollid wood with & 22 \\
\hline $\begin{array}{l}\text { Metal with rigid } \\
\text { loam core }\end{array}$ & 5.9 \\
\hline
\end{tabular}

These values are entered in the table anci the heat loss is calculated by dividing the door areas by the R-value. If the example bullding had more than one door type (dufferent $R$-values), then additional lines of the table would be completed.

Total

The heat loss of all components of the bullding envelope is summed at the bottom of the table and this completes Step A of the worksheet. 


\section{Step B. Foundation Perimeter Heat Loss}

Foundation heat loss from slabs. on-grade, basements and insulated crawlspaces is estimated by multiplying the length of perimeter times an approprlate heat loss factor taken from Table $B$.

The dining area, kdtchen and secondary bedrooms in the example house have slab-ongrade construction. R-7 insulation is installed around the perimeter.

The heat loss factor for the slab edge is 0.3 , selected from Table B. The heat loss factor is multiplied by the perimeter to calculate the heat loss. The units of heat loss, using the permeter method, are the same as for the bullding envelope calculated in the previous step. Note that sunspace slab is not included in this calculation. The slab edge perimeter adjacent to the crawlspace and the sunspace is also excluded.

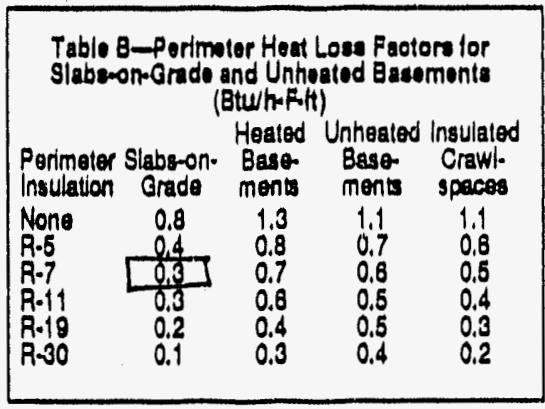

When a ratsed floor assembly is not insulated, for instance, over crawispaces insulated at the perimeter or basements, heat loss occurs primarlly at the perimeter.

The example house does not have a basement or a heated crawlspace, but if it did, the foundation heat loss would be calculated by multplying the permeter of these elements by a heat loss factor selected from Table B.

When houses have heated basements, heat loss from basement walls located above grade would be included in Step A.

Step C. Inflitration Heat Loss The herat loss from infiltration or air leakage is estimated by multiplying the bullding volume times the alr changes per hour times a heat loss factor of 0.018 .

The example building is estimated to have an infiltration rate of 0.50 based on local bullding expertence.
The bullding volume is calculated by multiplying the average celling helght by the conditioned floor area. In this example the average celling height is $8.3 \mathrm{ft}$. The conditioned floor area is 1,504 sf which does not include the garage or the sunspace. The resultung bullding volume is 12,483 cubic feet.

The units of infiltration heat loss are Btu $/{ }^{\circ} \mathrm{F}-\mathrm{h}$, the same as for the budlding envelope and the foundation perimeter.

\section{Step D. Total Heat Loss per Square Foot}

The total bullding heat loss is the sum of the heat loss for the bullding envelope (Step A), the foundation perimeter (Step B) and infiltration (Step C). For residences this value will range between 200 and 500 . It represents the Btu of heat loss from the building envelope over the period of an hour when it is one ' $F$ colder outside than inside. This total heat loss, of course, does not include heat loss from the solar systems, including direct gain glazing.

The result of Step $D$. huwever, is the annual heat loss per degree day per square foot. This value is calculated by multiplying the total heat loss by 24 hours/day and dividing by the conditioned floor area. 


\section{Step E. Conservation Performance Level}

Once the total heat loss per square foot is calculated, the conservation performance level may be calculated by multiplying the total heat loss per square foot (Step D) by the heating degree days times the hoating degree day multipller.

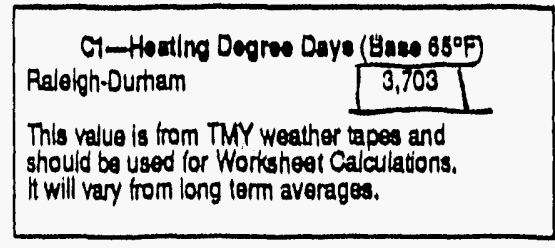

The heating degree days are selecter from Table $\mathrm{C} 1$ and based on speciflc locations. The heating degree day multiplier is selected from Table $\mathrm{C} 2$ and is based on the total heat loss per square foot (Step D) and the passtve solar glazing area per square foot of floor area (Worksheet II, Step A).

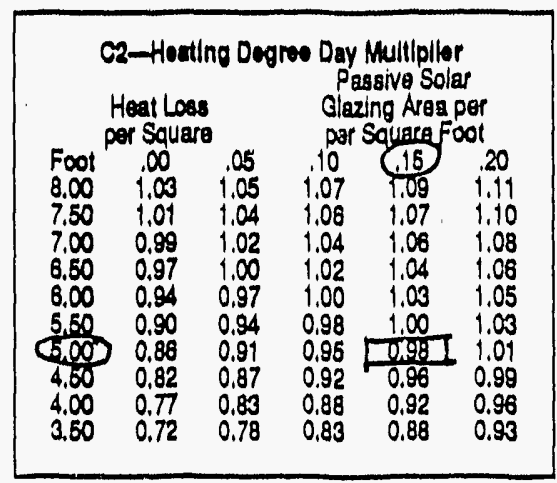

The conservation performance level for the example bullding is compared to the base case conservation performance level in the next step.

\section{Step F. Comparison} Conservation Performance The conservation performance level for the proposed design may be compared to the base case performance level for the area. glven in Table $D$.

Tablo D-Base Case Consorvation Pertormanos
(Btu/yrofi)
Base Case 25,380

Alternattvely, the conservation performance level may be compared to other bullding designs constdered by the bullder to be typical of the area. In this case, the worksheets would first be completed for the typical design and the results of these calculations would be entered in Step $F$.

If the conservation performance level of the proposed bullding (Step E) is greater than the base case or typical-design conservation performance level, the designer should consider additional bullding insulation or reduced non-solar glass area. 


\section{Worksheet II: Aurilliary Heat Performance Level}

A Projected Area of Passire Solar Glazdng

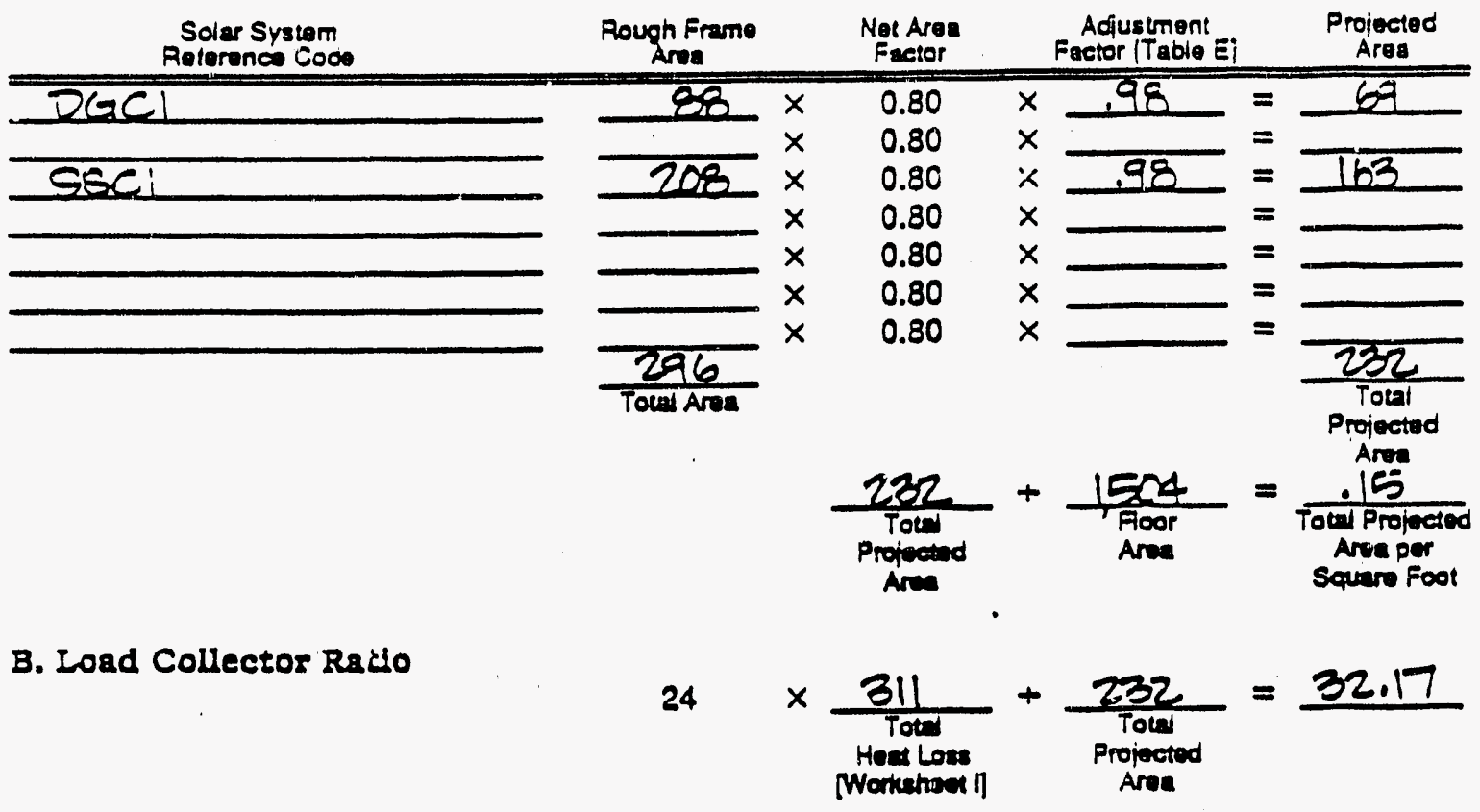

C. Solar Sarings Fraction

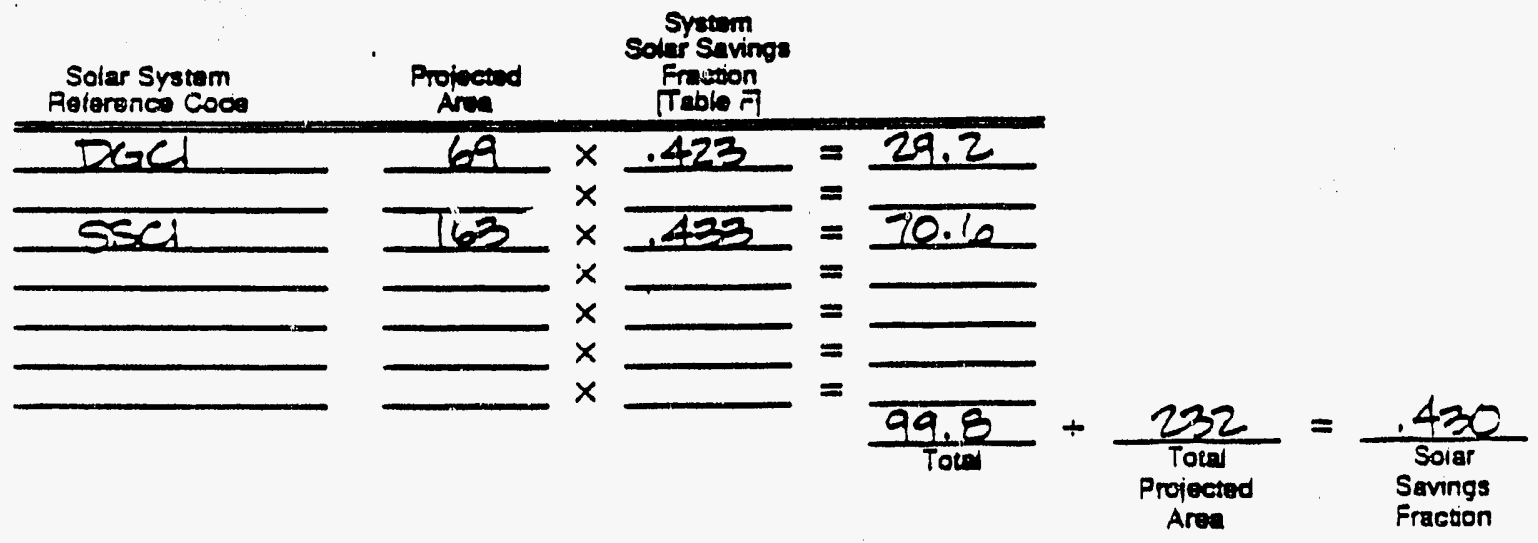

D. Audllary Eeat Performance Level

$$
\left[1-\frac{.43}{\substack{\text { Solar } \\ \text { Sevings } \\ \text { Fracion }}}\right] \times \frac{18,000}{\substack{\text { Conservacion } \\ \text { Portormanco } \\ \text { Lover Workstioer I. } \\ \text { Step E] }}}=10,260 \text { Brwyr.st }
$$

E. Corn parative Ausdllary Beat Performance (From Provious Calaulaion or from TabloG)

23,099 sturyr-si 
Worksheet II:

Auriliary Heat Performance Level

Worksheet II is used to estumate the savtigs from passtve solar systems and to estrmate the auxdlary heat performance level. This is the anount of heat that must be provided to the bullding each year after the solar savings have been accounted for.

The example bullding has two solar systems: direct gain south glazing and a sunspace.

\section{Step A. Projected Area of Passive Solar Glazing}

The first step is to calculate the projected area of the solar glazting. The projected area of passive solar glazang is the area projected on a plane facing true south (the actual glazing may be orfented slightly east or west of true south). The projected solar glawng also accounts for sioped glazdng in certaln types of sunspaces.

For most solar systems the projected area may be calculated by multuplying the actual glaxing area troes an adjustment factor taken from Table $\Xi$.

Alternatively, the projected area may be determund by mabong a scaled elevation drawng of tise building. lookeng eacrly north. Suriace areas may then be measured from the scaled elevation drawing. Tiss concept is Hustraced is the igure below.

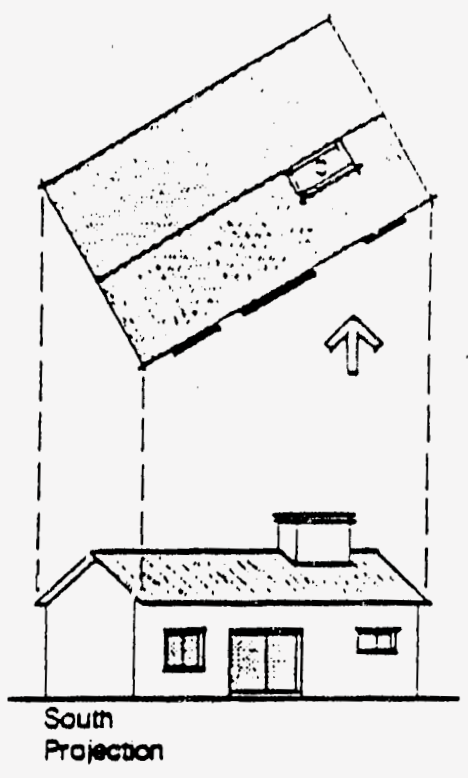

Propored Arew of Pacalve Solar Gizzing The soler savings fracion is based on the projected area of solar gierang.

The woriesheet allows the user to enter the rough Irame area of solar glazang. stace it is generally easter to measure this. The rough trame area is multiplied by a net area factor of 0.80 to account for window traming and mullions. If the net glass area is entered. the net araa lactor is 1. $\infty$.

The ample building has two separate passive solar systems: direct gain and a sunspace. This means that two lines of the table zusst be completed. If the example building had other types of solar systems. for instance Tromide walls or water walls, addituoral Hnes in the table rould be completed.

In the arst coluran. the reierence code for each rype of solar system is entered along arth a description of the system.
The reference codes are showt. on Tables Fl through $\mathrm{F} 4 \mathrm{io}$ varyous types of solar systerns. More information about the system types is proviced in the discussion under step $C$ of this workshest. The reierence code for the direct gat systaz. "st "DCCI" because night Lisuiation is not proposed. The reference code for che sunspace is "SSCI" since all the surspace glazing is vertical.

The south wall of the eample buلiding actually faces $10^{\circ}$ east of south because of site conditions. The adjustent factor is therefore 0.98 for both solar systeras as selected from Table E. Each solar system area is muitiplied by the net area factor and the approprlate adjusment factor to calculate the projected area. Both the total projected area and the toral area are surmorsed at the bottorn of the table.

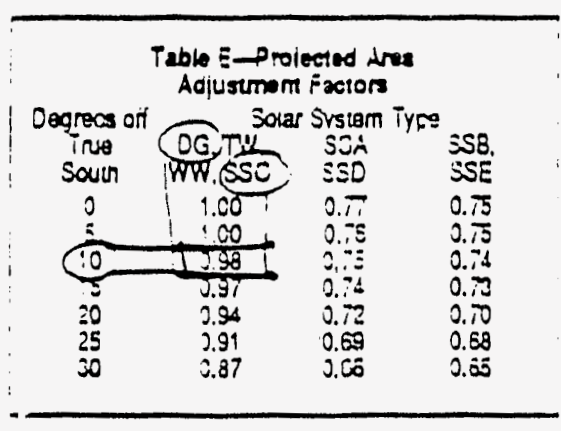

The last par of Step A is to ilride the total projected area by the conditloned lcor area. glving the total projecred area per square foot. This ralue is used In Worksheet i. Step $\equiv$ to derermane the heaung degres day roultiplier. 
Step B. Load Collector Ratio

The load collector ratio is calculated by taking the total heat loss from Worksheet I. Step $D$ and multiplying this value times 24 (hours/day) and dividing by the total projected area of the solar glazing calculated in the previous step.

\section{Step C. Solar Savings Fraction} The next step is to calculate the solar savings fraction for the butlding. This is calculated as a weighted average of the solar savings fraction for the separate passtve solar systems. The weightings are based on projected area.

The solar systems used in this step should be identical to those used above in Step $A$. The first two columns are simply carried down from the first and last columns in Step A.

The solar savings fraction fur each individual system is taken from Tables F1 through F4 based or the load collector ratio calculated in Step B and the type of solar system. Table FI is for direct gain systems, Table F2 for thermal storage wells, Table F3 for water walls and Table P4 for sunspaces. There are multiple columns in each table that account for system design features such as night insulatiun or selective surfaces.
A reference code, for instance "DGC1", is also provided for each solar system varlation. These references are entered on the worksheet "Solar System. Reference Code". They are also a key to addittonal intormation about each solar system as provided in Passive Solar Heattng Analysis and other reference manuals.
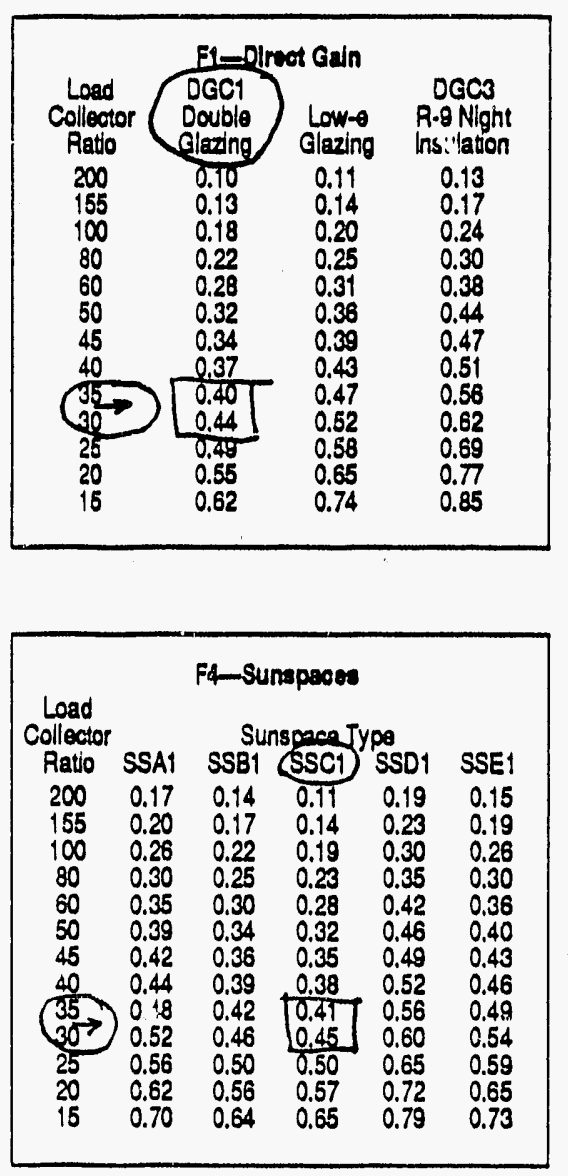

The solar savings fraction for each system is multiplied by the projected area and totaled at the bottom of the table. This total is then divided by the total projected area from Step A to calculate the weighted average solar savings fraction for the whole bullding.

The solar savings fractions are based on reference designs. The assuinptions made about these reference designs are summarzed below.

\section{Dtrect Gain}

The direct gain reference designs are all assumed to have doublepane glass and sufflcient heat storage to limit the clear day temperature swing to $13^{\circ} \mathrm{F}$. For the case with night insulation. the thermal resistance is assumed to be R-9.

\section{Trombe Walls}

The Trombe wall reference designs are all assumed to have double-pane glass. The mass wall is assumed to be 12 inches thick and construct 'd of masonry or concrete.

\section{Water Walls}

The water wall reference ciesigns are all assumed to have doublepane glass. The water tank is assumed to be nine inches thick. extending continuously in front of the glazing surface. The space between the water tank and the glazing is assumed to be sealed. 


\section{Surspaces}

Data is provided for ftve sunspace referemce designs as Whustrated on the follow'ng figure. Double glazting is assumed for all reference designs. Reference destgns SSAl. SSB 1 and SSD 1 are assurned to have opaque eno walls. All are assumed to have a concrete or masonry floor about six inches thick and a masonry or concrete comron wail separating the sunspace from the living areas of the house. The glazing for destgis SSAI and SSD 1 is assumed to be sloped at an angle of $50^{\circ}$ trom the hortzon. The sloped glazting in designs $B$ and $E$ is assumed to be at an angle of $30^{\circ}$.
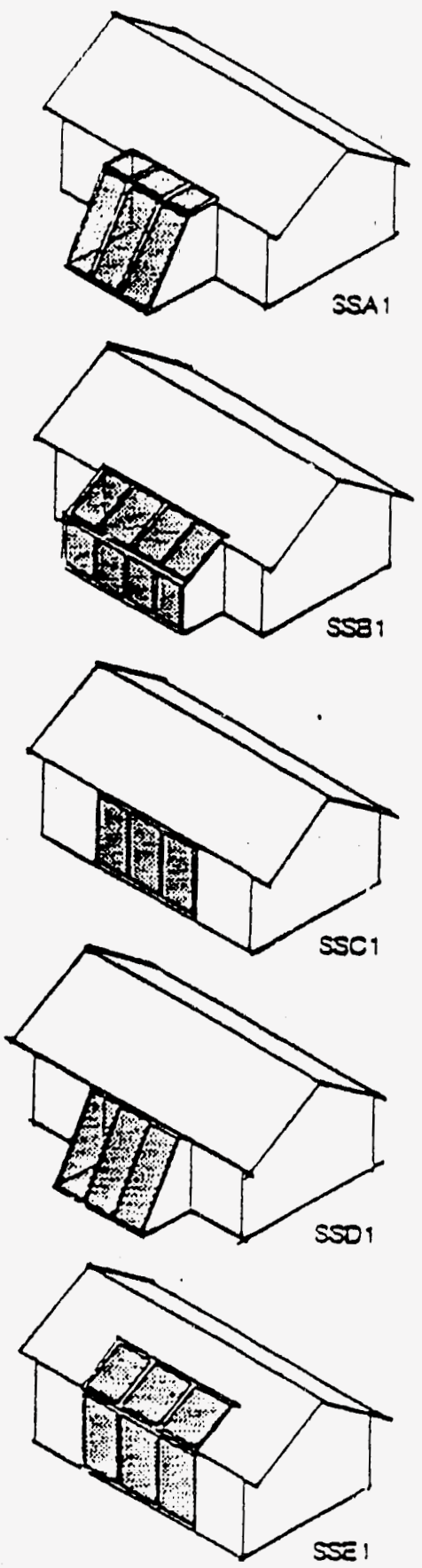

Sunsouce Rerenence Deaigne Date is pronded for five ypes of sunspacas.

\section{Step D. Audliarg Eeat Performance Level}

The aurdllary heat performance level is calculated by multuplying the conservation performance level from Worksineet I, Step $E$. trnes one minus the solar savtigs fraction. calculated in the previous step. This value represents the amount of heat that must be provided to the juilding by the auxdllary heating system(s).

\section{Step E. Comparative Audllary Eeat Parformance}

The calculated auxdlary heat performance level may be compared to the performance level for a typical basecase bullding in the area. This may be taken from Table $G$ and is 23.099 Btu/ys-sf.

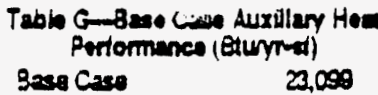

Alternattvely, the performance leve! zay be compared to a previous worksheer valculation made for a typical bulder house.

If the audellary heat performance level calculatea in Step $D$ were arger than the base case audilary heat periormance. the designer should consider lncreasing the size of the solar systems, adding additional solar systems or tncreasing insulation levels. 
Worksheet III: Thermal Mass/Comfort

A. Eeat Capacity of Sheetrock and Interior Furaishings

\begin{tabular}{|c|c|c|c|c|c|}
\hline & Foor Area & & $\begin{array}{c}\text { Urit } \\
\text { Heat } \\
\text { Caoacin } \\
\end{array}$ & & $\begin{array}{r}\text { Tolal } \\
\text { Heal } \\
\text { Caoacil } \\
\end{array}$ \\
\hline Rooms with Direct Gain & 464 & $x$ & 4.7 & $=$ & 213 \\
\hline Spaces Connected to Direct Gain Soraces & 949 & $x$ & 4.5 & $=$ & 427 \\
\hline
\end{tabular}

B. Eleat Capactty of Mass Surfaces Enclosiag Direct Gadr Spaces

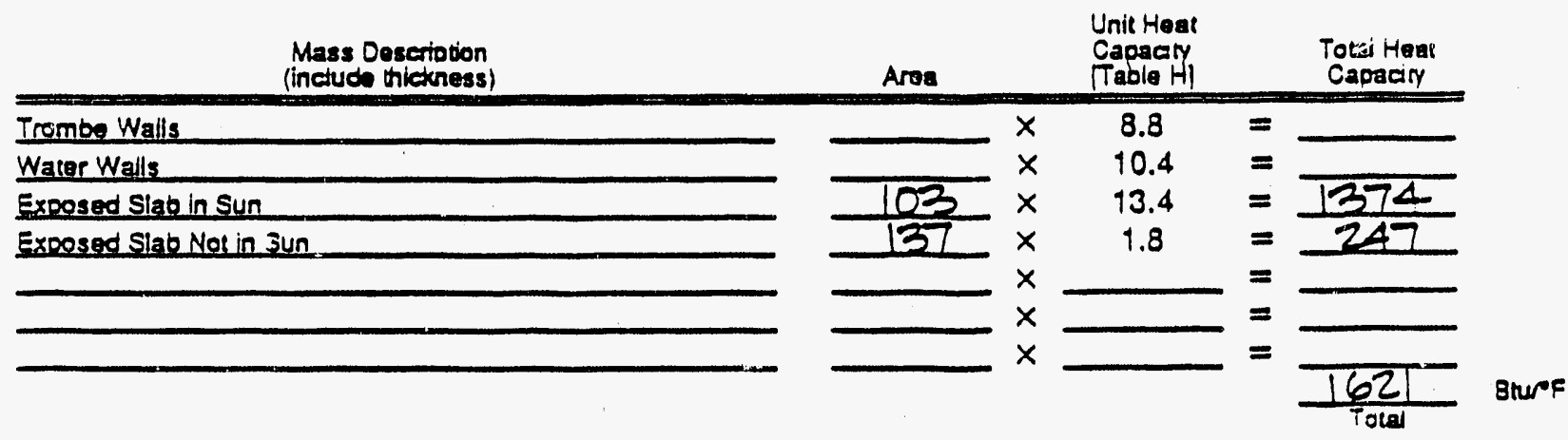

C. Eeat Capacity of Mass Surfaces Enciostog Spaces Connected to Dlrect Gatn Spaces

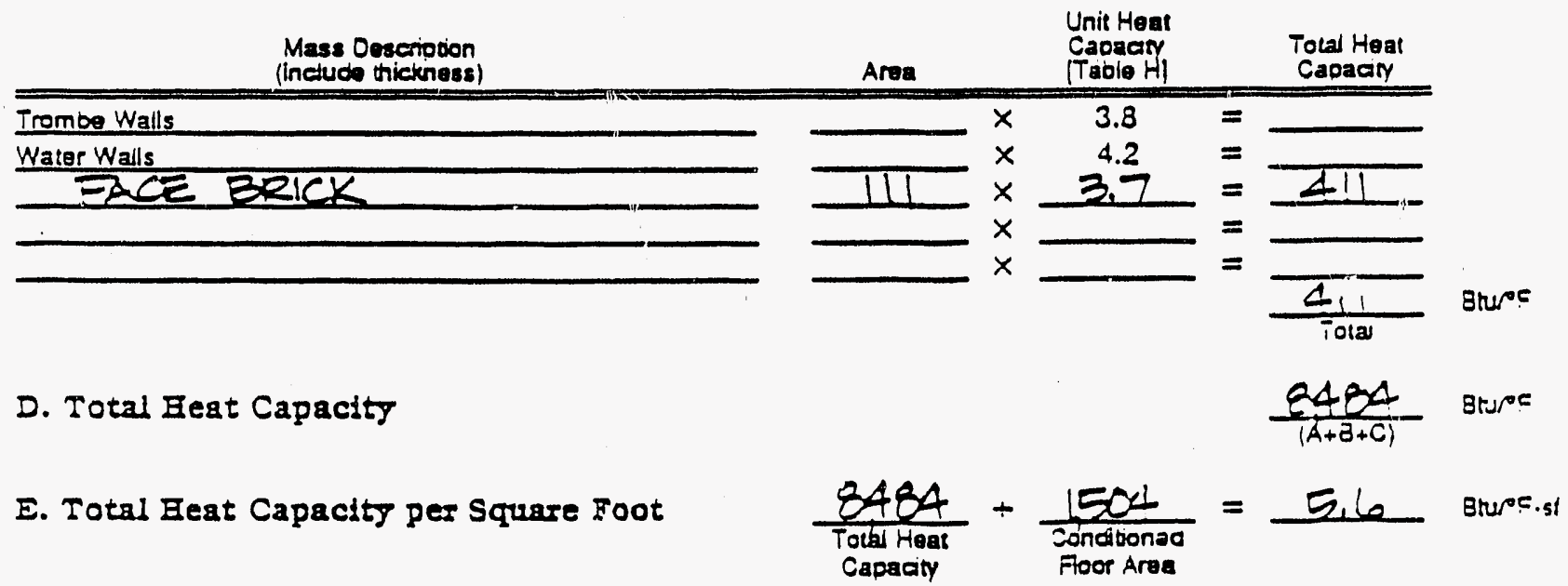

F. Clear Whter Day Temperatwre Swing

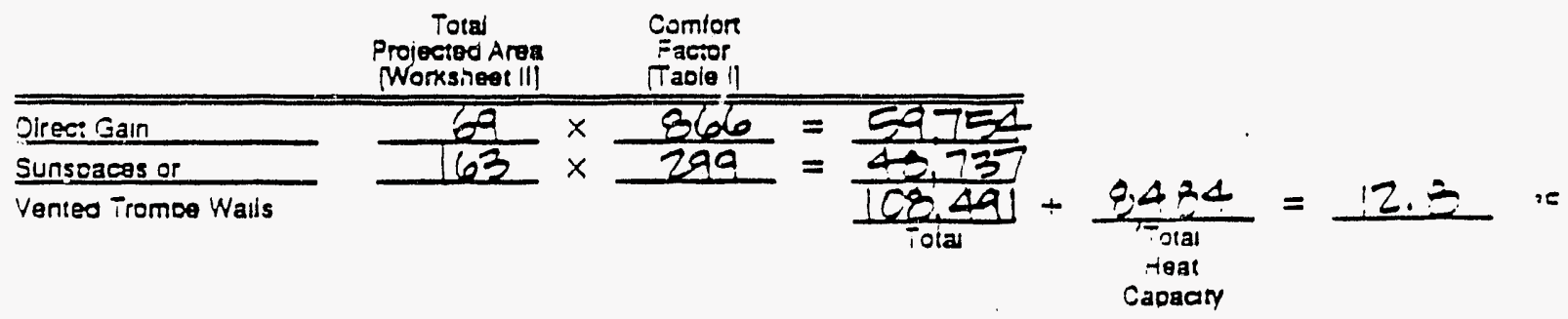

G. Recommended Madmum Temperature Swing

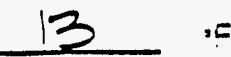

Compare Ldne $F$ to Line G 


\section{Worksheet III:} Thermal

\section{Mass/Cormfort}

This worksheet is used to calculate the thermal

mass/comfort periormance level. which is the remperature swing expected on a clear winier day with the auxdlary heating system not operating. A high remperature swing would indicate that inadequate thermal mass is provided in the butlding design. which not only creates discomfort but decreases solar heating performance.

The general procedure of the worlesheet is to calculate the effectrve heat capacity of mass elements located arthith the conditioned space of the buliding. The total effective heat capactry is then combined with the direct gain protected area to estronate the clear winter day temperature swing. Note that thermal mass elemencs located within unconditioned spaces such as the surspace are not Included in this calculation.
Step A Eleat Capactiy of Sheetrock and Interior

\section{Furatubings}

The Irst step is to estirnace the effectre heat capacity associared with low-mass constructon and intertor furmishings. To complete this step it is necessary that two sub-ayens be tdentifled withdo tho lududing: those areas that rowive ditrect solar gatns and those arieas that are connected to rooms that recetve direct solar gatos. Thts is because the mass of sheetrock and furntshings located to direct gata rooms is more effecture. Roows that are separated from direct gain spaces by more thas one door should not be inciuded in edther category.
In the exandie buldins, tis maste: becroor.. dinlug ara and kutcher. are all direcr gaur. spaces. The secondar: bedrooms, bathrooms and master bedroom closet are directly connected to the direc: galn spaces. The uttily room and entry foyer are not considered in this calculation since they are not connected to a drect gadn space. These areas are llustrated for the example bulding.

The direct gatn space is multiplied by 4.7 and the spaces connected to drect gatn spaces are multiplied by 4.5 . These products are sumned and represent the effective heat capacity assoctated with the sheetrock and interlor furnishings.

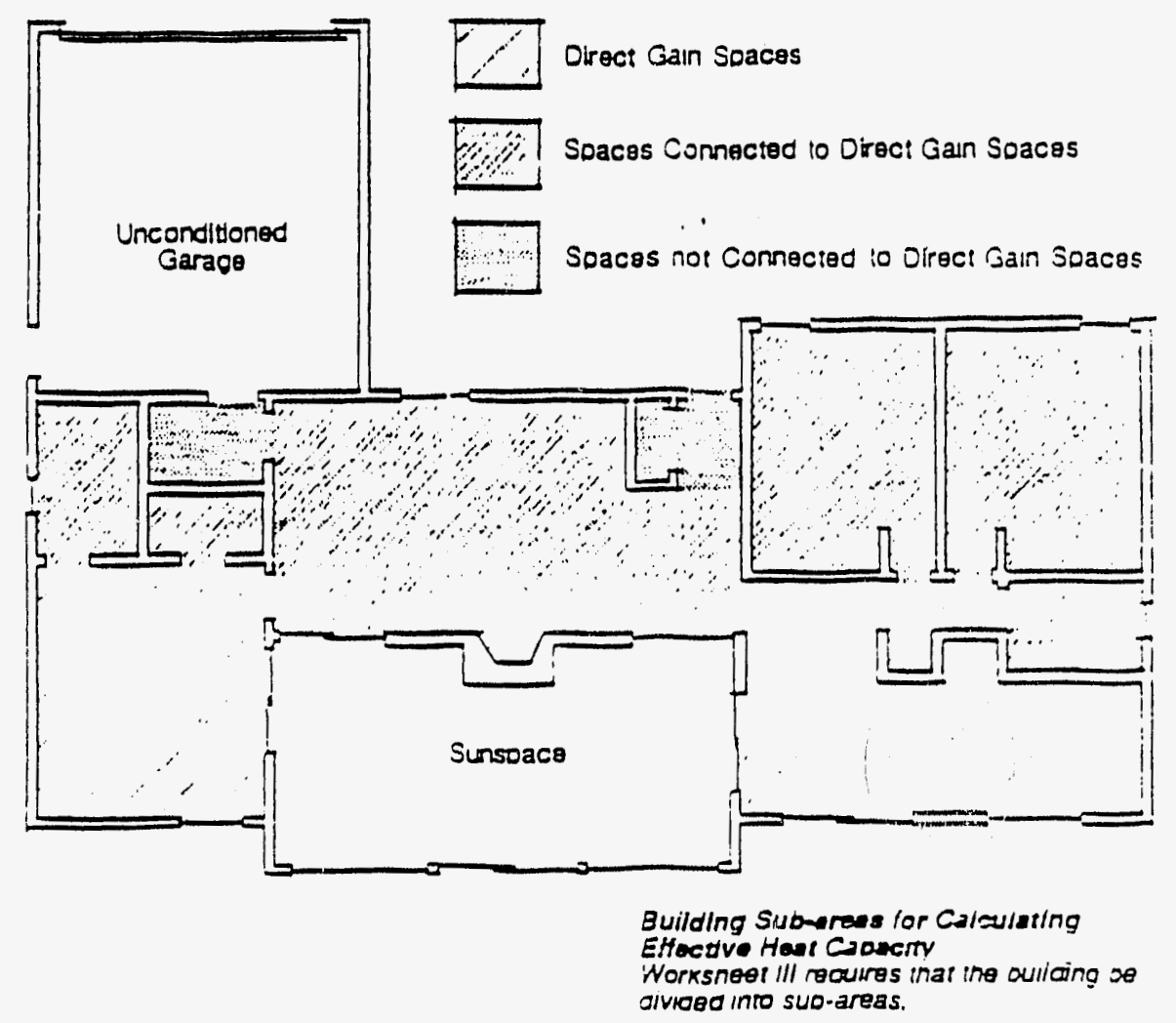


Step B. Heat Capacity of Mass Surfaces Enclosing Direct Galn Spaces

The heat capacity of thermal mass elements (other than sheetrock and furnishings) that enclose the direct gain spaces is considered in this step. The surface area of each element is measured from the bullding plans and multiplied by the unit heat capacity. The unit heat capacity is printed directly in the table for Trombe walls, water walls, and exposed slabs-ongrade. The unit heat capacity for other mass elements is selected from Table $\mathrm{H}$. Note that thermal mass located in the sunspace is not included in this calculation.

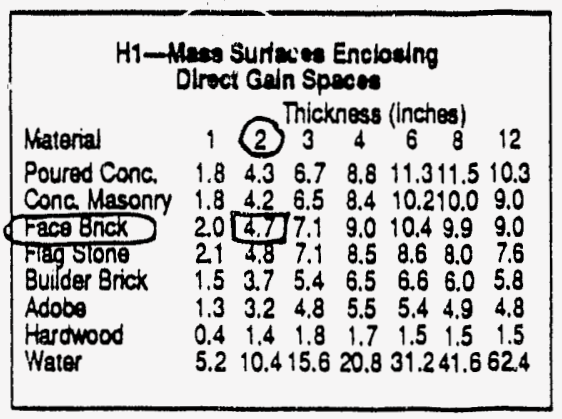

Exposed slabs-on-grade include those with a surface of vinyl tule, ceramic tlle or other matertals that are highly conductuve. Slabs that are covered with carpet should not be considered to be exposed. The exposed slab area should be further reduced, when approprtate, to account for throw rugs and furntshings.

The exposed slab area is then subdtulded into two areas: that which is expected to be in the sun and that which is not. As a rule-of-thumb, slab area should be considered in the sun only when it is located directly behind south glazing. In any event, the slab area assumed to be in the sun should not exceed 1.5 times the south glass area.

In the rxample bullding, the slabs-on-grade located in the kdtchen and dining room are located within direct gain spaces. Some of this area is considered to be in the sun and the remainder not. These surface areas are entered in the table and multilled by the appropriate unit heat capacity. The products are then summed at the bottom of the table.
Step C. Heat Capacity of Mass Surfaces Enclosing Spaces Connected to Direct Gain Spaces

The same type of calculation is performed for mass surfaces that enclose spaces connected to direct galn spaces. The primary difference is the unit heat capacity flgures taken from Table H2 instead of Table H1.

In the example bullding, the fireplace wall and hearth are considered in this category. This area and the undt heat capactty is entered in the table and multiplied by each other. This represents the total effective heat capacity of mass elements that enclose the spaces connected to direct gain spaces.

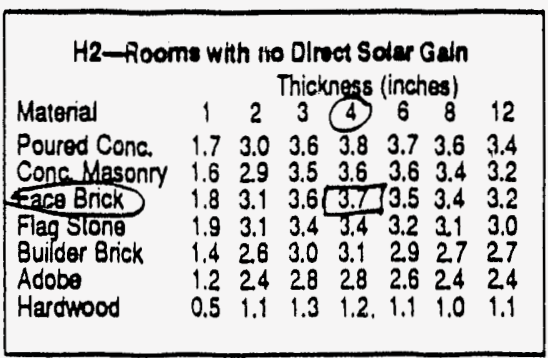


Step D. Total Heat Capacity The total heat capacity is the sum of the heat capacity from Steps A, B and C. This represents the effecttve heat capacity of all thermal mass within the bullding.

Step E. Total Heat Capactty per Square Foot

The total heat capacity calculated in Step D is divided by the total floor area of the bullding to get the total heat capacity per square foot. The floor area used in this calculation should not include the sunspace or other unconditioned spaces. This value is calculated here for conventence, but it is not used untll Worksheet $I V$ is completed.
Step F. Clear Winter Day Temperature Swing

The clear winter day temperature swing is calculated In Step F. The projected area of all drect gain glazing is entered in the first row. This includes all drect gain systems either with or without night insulation. In the second row, the projected area of sunspace glazing and Trombe walls vented to the Indoors is entered. Unvented Trombe walls and water walls are not included in this calculation since solar gain from these systems does not contribute to the temperature swing of the conditioned space.

The appropriate comfort factor is entered in the second column, selected from Table I. The projected areas are multiplied by the approprate comfort factors and summed. This sum is then divided by the total heat capacity from Step $D$ to yield the clear winter day temperature swing.

l'able L-Comiort Factors (Btw/st)
Direct Gain
Sunspaces and
Vented Trombe Walls

Step G. Recommended Mardmum Temperature Swing The comfort performance target for all locations is $13^{\circ} \mathrm{F}$, If the comfort performance level calculated in Step $F$ had been greater than $13^{\circ} \mathrm{F}$, addittonal thermal mass should be added to the bullding or direct gain glazing should be reduced. 
Worksheet $\Pi$ : Summer Cooling Pefformance Leve!

A. Opaque Suriaces

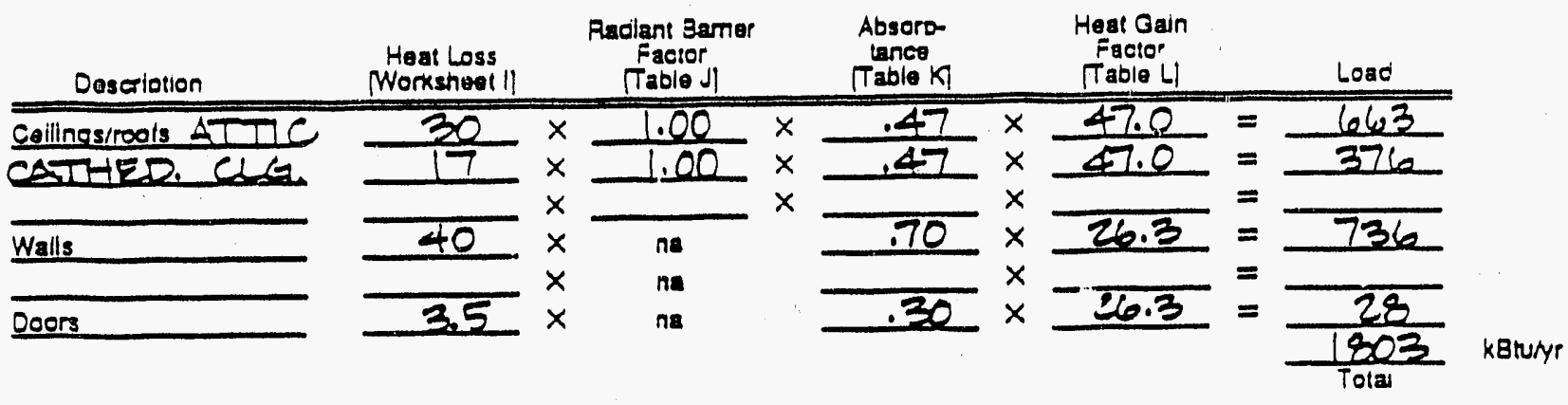

\section{B. Non-solar Giaztog}

\begin{tabular}{|c|c|c|c|c|c|c|c|c|c|}
\hline Descipton & $\begin{array}{c}\text { Rough Frume } \\
\text { Area }\end{array}$ & & $\begin{array}{l}\text { Nat Arva } \\
\text { Facter }\end{array}$ & & $\begin{array}{c}\text { Shade Factor } \\
\text { Trable M] }\end{array}$ & & $\begin{array}{l}\text { Heat Gain } \\
\text { Facror (Tabie L) }\end{array}$ & & Load \\
\hline North Glass & 40 & $x$ & 0.80 & $x$ & - & $x$ & & $=$ & 995 \\
\hline East Glass & 6 & $x$ & 0.80 & $x$ & .00 & $x$ & 6 & $=$ & 331 \\
\hline West Glass & 6 & $x$ & 0.80 & $x$ & .00 & $x$ & .2 & $=$ & 351 \\
\hline Skyliohts & & $x$ & 0.80 & $x$ & & $x$ & & $=$ & \\
\hline
\end{tabular}

\section{Solar Glazing}

\begin{tabular}{|c|c|c|c|c|c|c|c|c|c|}
\hline $\begin{array}{c}\text { Soler System } \\
\text { Deseription }\end{array}$ & $\begin{array}{c}\text { Rough Frame } \\
\text { Area }\end{array}$ & & $\begin{array}{c}\text { Net Area } \\
\text { Factor }\end{array}$ & & $\begin{array}{c}\text { Shade Factor } \\
\text { [Table Mi }\end{array}$ & & $\begin{array}{c}\text { Heat Gain } \\
\text { Factor Table Li }\end{array}$ & & Load \\
\hline Direce Gain & 83 & $x$ & 0.80 & $x$ & .83 & $x$ & $E 5.0$ & $=$ & 3214 \\
\hline Storage Walls & & $x$ & 0.80 & $x$ & & $x$ & & $=$ & \\
\hline Sunsoace $<$ & 205 & $x$ & 0.80 & $x$ & .83 & $x$ & 12.2 & $=$ & \\
\hline & & $x$ & 0.80 & $x$ & & $\times$ & & $=$ & \\
\hline
\end{tabular}

D. Internal Gado

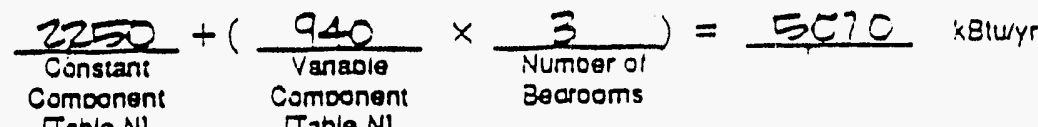
TTable Nl [Table N]

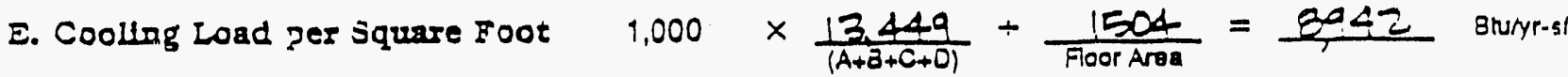

F. Adjugtment for Thermal Kass and Ventllation

736 gru/yr-si

G. Coollng Performance Level $\frac{8205}{B \cdot \bar{E}:}$ stryr.st

H. Comparison Coollag Performance (From Prenous Cuaviason or trom iade P) q-ibio sturr.st 


\section{Worksheet IV: Summer Cooling Performance Level}

Worksheet $I V$ is used to calculate the summer coollng performance level. This is the heat that would need to be renuved from the bullding by an air condittoner in order to malntaln comfort during the summer.

The worksheet accounts for four sources of cooling load: opaque surfaces exposed to the sun, non-solar windows, passtve solar systems, and internal gain. These loads are then adjusted to account for venttlation and thermal mass.

\section{Step A. Opaque Surfaces}

Not all upaque surfaces contribute to the cooling load of the building; only those surfaces exposed to sunllght (cellings/roofs and walls) are included in the calculation. For each celling and wall surface Listed on Worksheet I and exposed to the sun, the heat loss should be carried over to this worksheet along with a consistent description. This heat loss is then multiplied by a radiant barrer factor when approprate (from Table J), the absorptance (from Table $\mathrm{K}$ ) and a heat gain factor (from Table L). The end product of this calculation is an estimate of the annual cooling load that is assoctated with each surface in thousards of Btu per year (kBtu/yr).

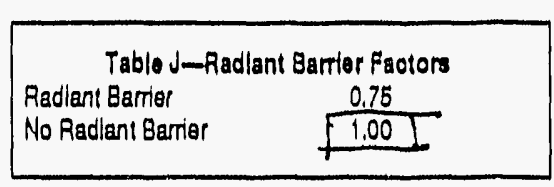

\begin{tabular}{|c|c|}
\hline \multicolumn{2}{|c|}{ Table K-Solar Absorptanoses } \\
\hline 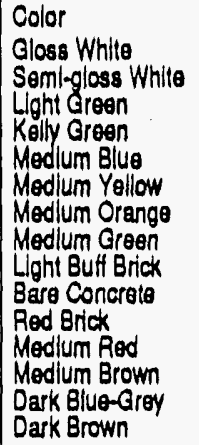 & $\begin{array}{c}\text { Absorptanco } \\
0.25 \\
0.30 \\
0.47 \\
0.51 \\
0.51 \\
0.57 \\
0.58 \\
0.69 \\
0.60 \\
0.65 \\
0.70 \\
0.80 \\
0.84 \\
0.88 \\
0.88\end{array}$ \\
\hline
\end{tabular}

\begin{tabular}{|c|c|c|}
\hline \multicolumn{3}{|c|}{ Tablo L-Hoat Gain Faotors } \\
\hline $\begin{array}{l}\text { Ceilling/roois } \\
\text { Walls and Doors } \\
\text { North Glass } \\
\text { East Glass } \\
\text { West Glass } \\
\text { Skyllights } \\
\text { Dirroct Gain Glazing } \\
\text { Trombe Walls and } \\
\text { Water Walls }\end{array}$ & $\begin{array}{c}47.0 \\
26.3 \\
37.0 \\
68.9 \\
73.2 \\
134.2 \\
55.0 \\
12.2\end{array}$ & \\
\hline $\begin{array}{l}\text { SUnSpaces } \\
\text { SSA1 } \\
\text { SSB1 } \\
\text { SSC1 } \\
\text { SSD 1 } \\
\text { SSE1 }\end{array}$ & $\begin{array}{l}39.3 \\
39.3 \\
12.2 \\
39.3 \\
39.3\end{array}$ & $\checkmark$ \\
\hline
\end{tabular}

In the example bullding, four lines of the table are completed. two for the celling/roof types. one for the exterior walls with brick veneer and one for the entrance door. The wall that separates the house from the garage and the door in this wall are not included, since they are not exposed to sunlight.
The heat loss from each of these elements is carried over from Worksheet I. Note that the door heat loss is reduced by half since one of the two doors does not recetve sunlight. The proposed bullding does not have a radlant barrier in the attic, so the radiant barrier factor is 1.00 . Absorptances are selected based on the exterfor bullding colors and the heat gadn factors are from Table L.

\section{Step B. Non-solar Glazing}

Cooling load assoctated with the windows that do not face south, 1.e. those that are not part of one of the solar systems, is calculated by multiplying the surface area in each ordentation times the net area factor, a shade factor (from Table $M$ ) and a heat gain factor (from Table L). Thts calculation gives the annual cooling load for each non-solar glazed surface. The total for the bullding is the sum of the cooling load for each surface.

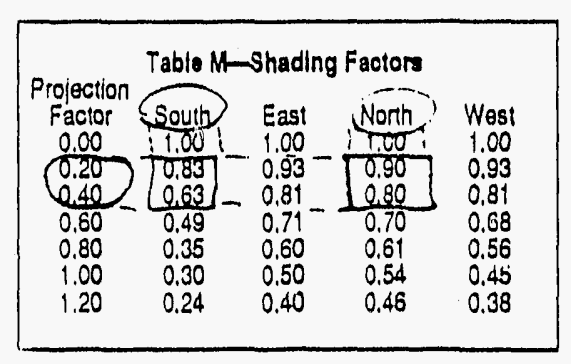

The rough frame area is generally entered in the table and adjusted by the net area factor. If the net glazing area is entered instead, then the net area factor is 1.00 . 
Table $M$ glves the shade factor for overhangs. The overhang shade factor depends on the ordentation of the window and the projection factor. The projection factor is the overhang projection divided by the distance from the bottom of the window to the bottom of the overhang, as lllustrated below.

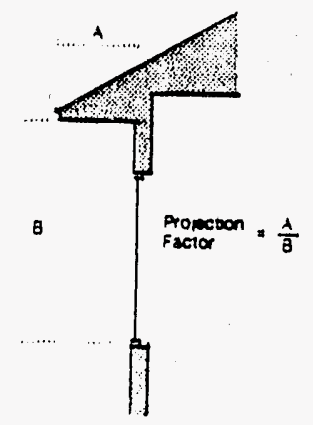

Overhang Projoction Factor

The projection factor is the overhang projection divided by the distance between the bottom of the window and the bottom of the overhang.

The north windows have a height of four feet and the bottom of the overhang is about six inches above the window head. The overhang projection is 1.5 feet. The projection factor is calculated by dividing the overhang projection by the distance from the bottom of the window to the bottom of the overhang. This is about 0.33 . A shade factor of 0.84 is used in the calculations, which is Interpolated between the values for a projection factor of 0.2 and 0.4
If the example bullding had tinted glazing, glazing fllms or external shading devices, the shade factors from Table $M$ should not be used. Sunscreen and glass manufacturers usually rate the shading effect of their devices by publishing a shading coefficient. The shading coefficient is a number between zero and one that indicates how much solar heat makes it through the window compared to an unshaded 1/8 inch clear pane. This shading coefficient may be used in the calculation instead of the value from Table $M$.

The overhang on the east and west is at the eave, well above the window, and does not provide any useful shading. For these windows, the shade factor is 1.00 .

Each glazing area is multiplied by the net area factor and the approprlate shade factor. The products are summed at the bottom of the table.

\section{Step C. Solar Glazing}

The solar systems addressed on Worksheet II reduce heating energy, but they also can increase cooling energy. The cooling energy impact of the solar systems is calculated in this step. Each solar system Usted on Worksheet II should be carried over to this worksheet. The cooling energy for each system is calculated by multiplying the total surface area (not the projected area) times the net area factor, the appropriate shade factor (as discussed above) and a heat galn factor (from Table L). This calculation gives the annual cooling load for each passive solar system.

A shade factor of 0.83 is used because of south overhangs. This is based on a projection factor of about 0.2 as discussed above.

The annual cooling load associated with all the passive solar systems is summed at the bottom of the table. 


\section{Step D. Internal Gains}

The last component of coolling

load is from internal gain. Internal gain is heat given off by Ughts, appliances and people.

Some of the cooling load assoclated with internal gain is considered to be constant for all houses regardless of the number of bedrooms or stze. This is because all houses have a refrigerator and at least one occupant. Another component of cooling load from internal gain is considered to be varlable and depends on the number of bedrooms. These components are accounted for separately in the calculation.

Both the constant component and the variable component are taken from Table N. The variable component is multiplled by the number of bedrooms in the house and added to the constant component to yleld the total cooling load from internal gain.

Table N-Intemai Gain Factor Constant Component $\quad 2,250 \quad k B$ tulyr Variable Component $\quad 340$ kBturyr-BR

Step E. Coollng Load per Square Foot

This step sums the cooling load assoclated with opaque surfaces, non-solar glazing, passive solar systems and internal gain (Steps $A, B, C$ and D). The sum is then divided by the floor area of the bullding and multiplied by 1,000 to convert the cooling energy into terms consistent with the base case coollng performance.
Step F. Adjustment for Thermal Mass and Ventilation The total cooling load calculated in Step $\mathrm{E}$ is adjusted in this step to account for the effects of thermal mass and ventllation.

The adjustment depends on the total heat capacity per square foot caiculated on Worksheet III. Step E, but also depends on whether or not the bullding has night ventulation or celling fans. The adjustment is entered in the blank in Step F.

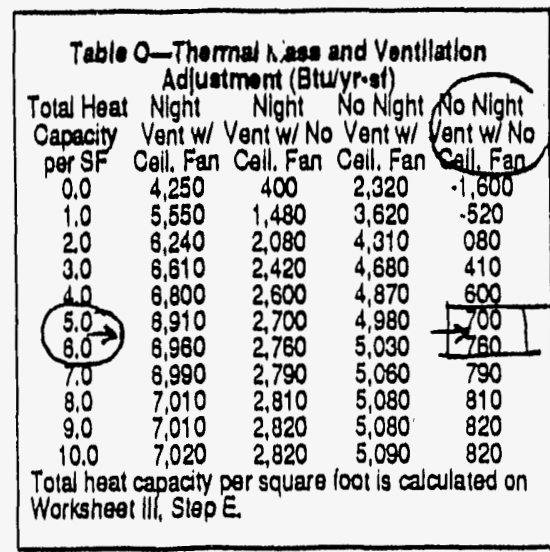

The example bullding has a total heat capacity per square foot of 5.6. It has netther night ventilation nor celling fans.

Night ventulation is a bullding operation strategy where windows are opened at night when the atr is cooler. The cool night alr allows heat to escape from the thermal mass elements in the bullding. The cooler thermal mass elements help keep the bullding comfortable the following day when alr temperatures rise.

\section{Step G. Coolling}

Performance Level

The summer coollng

performance level is calculated by subtracting the adjustment in Step $F$ from the coollng load per square foot calculated in Step $\mathrm{E}$. This is an estimate of the amount of heat that must be removed from the bullding each year by the air conditioner.

\section{Step H. Comparison Cooling Performance}

The cooling performance level for the proposed design may be compared to the base case cooling performance level for the area, given in Table $P$.

Table P_Base Case Coollng Portormance Base Case (Btw/at-yr) 9,766

Alternatively, the cooling performance level may be compared to other building designs considered by the builder to be typical of the area. In this case, the worksheets would first be completed for the typical design and the results of these calculations would be entered in Step $\mathrm{H}$.

If the cooling performance level of the proposed building (Step G) is greater than the base case or typical-design conservation performance level, the designer should consider measures to reduce the cooling performance level. Such measures might include reducing non-solar glass. providing additional shading or increasing thermal mass. 


\section{Technical Basls for the Bullder Guddellines}

\section{How These Guidellnes Were Produced}

The Bullder Ouldeline, Worksheet, and Example booklets have each been generated by merging two flles in a milorocomputer. The flrst, containing the text, is a word-processor file which does not ohange from location to location. The second is a ile of numbers and text which is location dependent. This flle is produced by running a spectal milorocomputer program which caloulates performance numbers based on long-term monthly weather and solar data compiled by the Natonal Oceanio and Atmospheric Administration for the partloular locality selected. The merged Ales, with all the numbers and text slotted into their proper place, are then run off on a laser printer to produce the camera-ready copies of the booklets.

\section{More Thun a Decade of Expperience}

The concentrated effort of research. design, construction, and evaluation of actual bulldings which started at the Passive Solar Conference in Albuquerque In 1976 has contunued up to the presert. It has been estumated that more than 200,000 passive solar houses have been built in the United States during this time. These Guldelines distlll the wealth of experlence which has been obtained from this massive effort.

\section{Analywis Procodures}

The numbers which appear in the Guddelines and Worksheets have been calculated using well established procedures for estimating the performance of passive solar and natural coollng strategles. Each of these procedures were developed at the Los Alamos National Laboratory with funding from the US DOE Solar Bulldings Program.

\section{Conservation Performance}

The heat loss calculation on Worksheet ! is based on a stralghtforward summation of the tradittonal elements whiluh make up the budlding heat loss coefflolent (expluding the solar components). The Conservation Performance Lovel is oaloulated by multiplying this loss coefficlent by annual degree days. Degree-days for each month have been determined using an appropriate base temperature which accounts for an assumed thermostat setting of 70 ' $\mathrm{F}$, an assumed Internal heat generation of $3 E 1$ Btu/day per sq $\mathrm{ft}$, and the building los/3 coeffodent. This forms the basis of the Henting Degree Day Multuplier in Worksheet Table C1. The result of the Worksheet is an estumate of the annual heat required to maintain comfort. excluding both posittve and negative effects due to the solar components. In this estimate, no solar heating credit ti given to east, west and north windows, because it is assumed that these will be protected by vegetation or other shadirig in accordance with the Guddeline recommendations. This is a conservative assumption since there will always be some solar gains through these windows.

\section{Passive Solar Heating Performance}

Passive solar heating performance is calculated using the Solar Load Ratio (SLR) method (refs. 1 and 2). Monthly' solar savings fraction (SSF) values are determined using correlation lits to the results of hourly computer simulation calculations for a variety of cllmates. These are then combined into the annual values listed in Worksheet Tables F1-F4. The SLR method glves answers which agree within about $5 \%$ of the hourly computer simulations and within $11 \%$ of the measured passive solar performance of 55 houses monitoned uider the US DOE Solar Program. The SSF estumates account properily for both gains and losses and thus correct for having omitted solar components from the bullding loss coefficlent.

\section{Temperature Swing}

The temperature swing estimation on Worksheet 3 is based on the Dlumal Heat Capacity method (ref.' 3). The method is an analytical procedure in which the total heat stored in the house during one day is estimated by summing the effeotlve heat storage potential of the all the various materials in the house for a 24-hour pertodic cycle of solar input (the diurnal heat capacity or dho). Rooms with direot gain are assumed to have radiative coupling of the solar heat to the mass. Roome connected to rooms with direet gain are assumed to have conveottve coupling, which is rather less effective, espectally for massive elements. The dhe of the sheetrock, framing and furniture are approxdmated as 4.5 or 4.7 Btu/ ${ }^{\circ} \mathrm{F}$ per sq ft of loor area. Worksheet Tables $\mathrm{H} 1$ and H2 list dhe values for varlous conventional materials which are ofter used to provide extra heat storage, assuming that these materials replace sheetrook.

The only numbers in Worksheet III that are locatton dependent are the Comfort Factors, taken from Table 1. The direct-gain comfort factor is $61 \%$ of the solar gain transmitted through vertinal, south-facing double glazing on a clear January day. The driving effect of sunspaces and vented Trombe walls is assumed to result in one-third this value, based on data from monitored bulldings. The origin of the $61 \%$ factor is described in the references.

\section{Summer Cooling Performance}

The purpose of including the summer cooling estimates is only to determine if excessive cooling will result in a house designed for passive solar heatuig and to provide a rough estumate of the effectveness of natural cooling strategles. The analysis method used !s based on modifled monthly degree-day method in which the day is divided into day and night periods (ref, 4). All estimates are derived from correlations based on hourly computer simulations. 
Solar, conduotion, and Internal galns are estumated for each half-day period in each month. Delay factors are used to account for heat carry-over from day to night and night to day. The results reported are estimates of annual sensible cooling requited by the house and do not include latent loads.

Stnce the original Los Alamos monthly procedure is too complex to be implemented in a worksheet, a simplifled procedure is adopted on Worksheet IV. Heat Oain Factors and In ternal Gain Factors $L s$ Tables $L$ and $N$ are the caloulated annual incremental cooling loads due to a one-unit incremental change in the respective heat input f. urumeter (that is, a one unit change in UA, glazing area, or number of bedrooms). The combined heat load due to all inputs is summed and then adjusted for thermal mass and ventilation. This correction includes a constant required to achieve the calculated coolling load of the base-case house. This linearized procedure will glve accurate estimates for cooling loads which are less than about $150 \%$ of the base-case house: however, it will underestumate very large cooling loads in poorly designed houses.

The adfustment factors for ventllation properly account for maintaining comfort in hot and humid climates. Ventilation is restricted to times when the outside dewpoint temperature is less than 62 ' $F$. This restriction will avold ventlation when humidity would cause discomfort.

\section{Not for Slating Equipment}

All heating and cooling values given in the Guidelines Tables and numbers calculated using the Worksheets are for annual heat delivered or removed by the mechanical heatung or cooling systeri. There is no direct way to use these numbers for sizing the capacity of ihis equipment. The methods developed by ASHRAE for stzing equipment are wellestablished and are recommended. The purpose of the guidance provided in these booklets is to minimize the operating tume and resources consumed by this equipment.

\section{Uaing the Guddellnes in other Location:}

Much of the guidance provided is applicable almost anywhere. The basic techriques of conservatton, passive solar heating, and natural cooling are universal. However, a major value of these Guldelines is in providing locationspecifle performance values. These can vary widely, even within one State. Most of the numbers which appear in these booklets are caloulated using data measured at a partloular weather station and therefore apply only in that vicinity.

The applicabllity of Worksheets I and II can be extended somewhat by using base-65 ' $F$ degree-day values for a site which is close to the location for which the Worksheet tables were generated. The recommendation is to limit such application to sites for which the annual heatung degree-days are within plus or minus ten percent of the parent location and where it is reasonable to assume that the solar radiation will be about the same as in the parent location. The procedure is simple: use the measured base-65 ' $F$ degree-days in Workaheet I, Line $F$, Instead of the degree-days for the parent location.

Worksheet III depends only weakly on location. The only variables are the Comfort Factors in Table I which change with only with lattude. Thiss this Worksheet can be used anywhere within 4 degrees of lattude of the parent. location.

The Cooling Performance Level results obtained from Worksheet IV are spectilc to the locallty of the Guidelinies. Within the same vicinity ard within plus or minus twenty percent, the result could be adjusted, based on a ratlo of cooling degree-days.

\section{Cotting Eata}

Heatng and cooling degree-day data can be obtained from the National Climatio Center, Asheville, NC. Refer to Climatography of the United States No. 81 whideh lists monthly normals for the period $1951-80$ on a state-by-state basis. There are over 2400 locatlons listed in this data base.

\section{References}

1) J. Douglas Balcomb, Robert W, Jones, Robert D. McFarland, and William O. Wray, Expanding the SLR Method, Passive Solar Journal Vol. 1 No. 2, pp 67-90, 1982.

2) J. Douglas Balcomb, Robert W, Jones, Robert D. McFarland, and William O. Wray, Passive Solar Heating Analysis, American Society of Heatung, Cooling and AirConditoning Engineers, 1084.

3) J. Douglas Balcomb, and Wullam $O$. Wray, Passive Solar Heating Analysis, Supplement One, Thermal Mass Effects and Additlonal SLR Correlations, American Soctety of Heating, Cooling and AlrCondittoning Engineers, 1987.

4) Robert D. McFarland and Guorla Lazarus, Monthly Auxillary Cooling Esthmation for Residential Buildings, Los Alamos National Laboratory Report, in press. 


\section{DESIGN DETAILS}




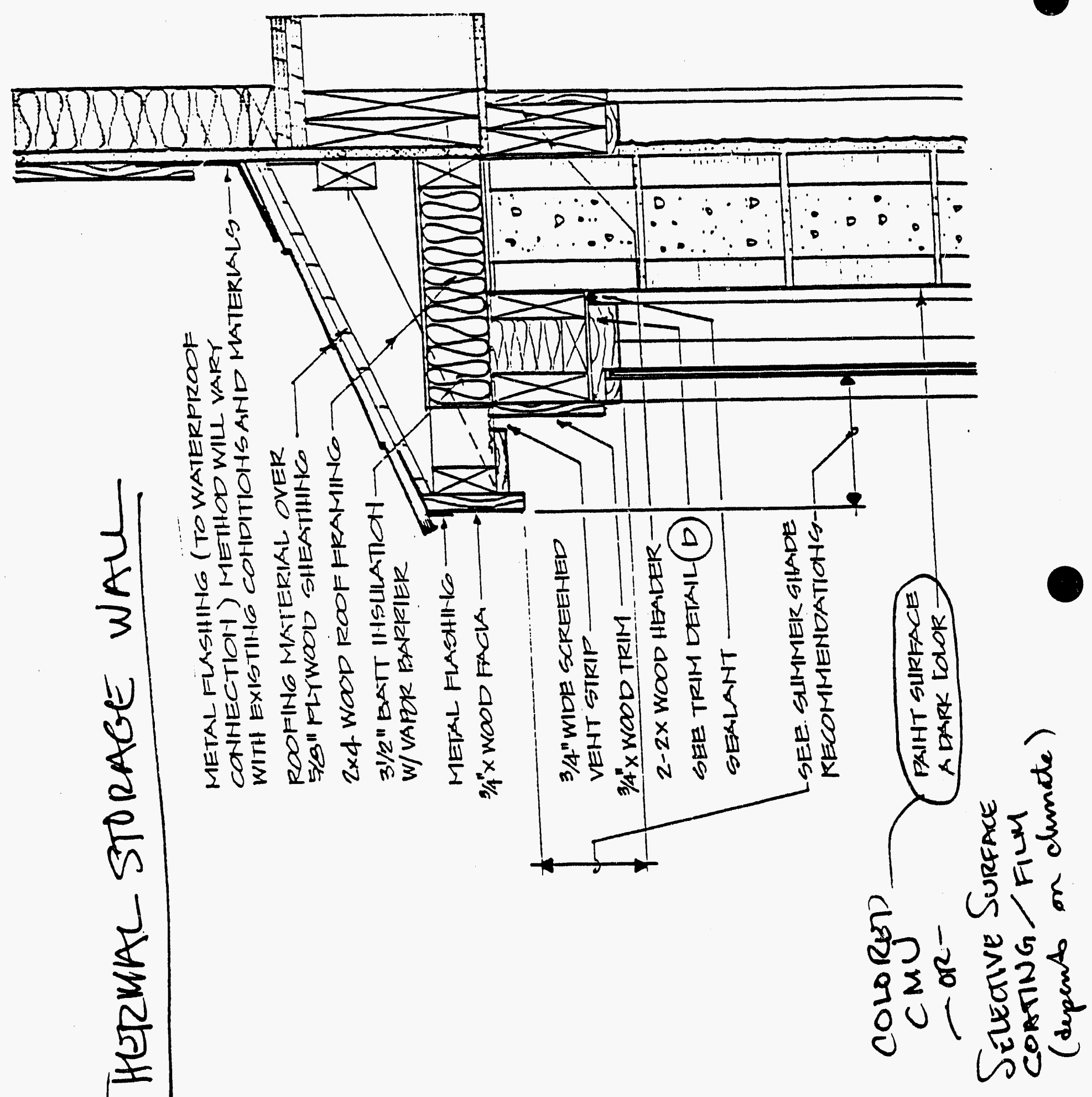


Direct Goin

Conventional Window

Wood Frame Wall
3.1200

\section{Detail}

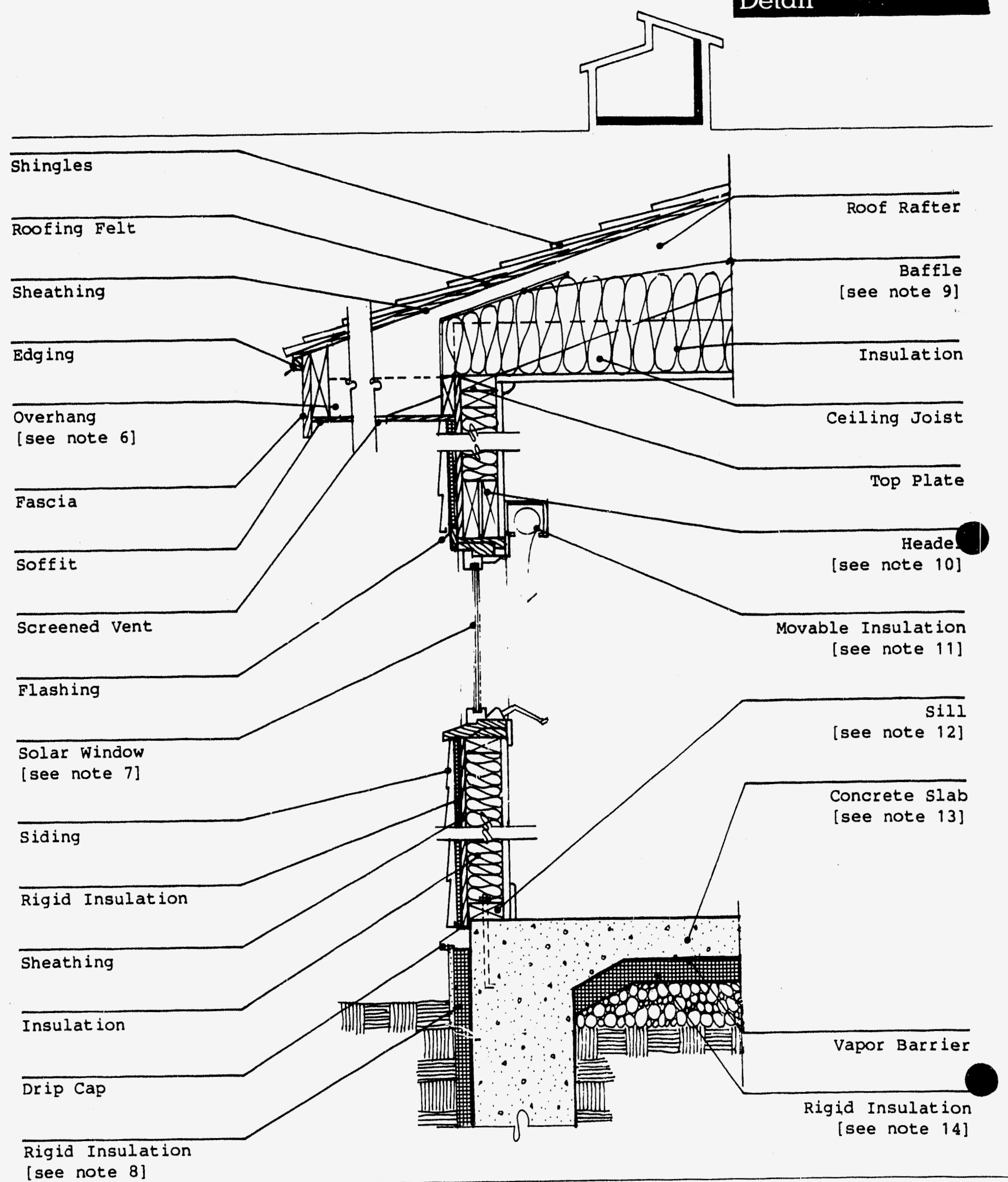




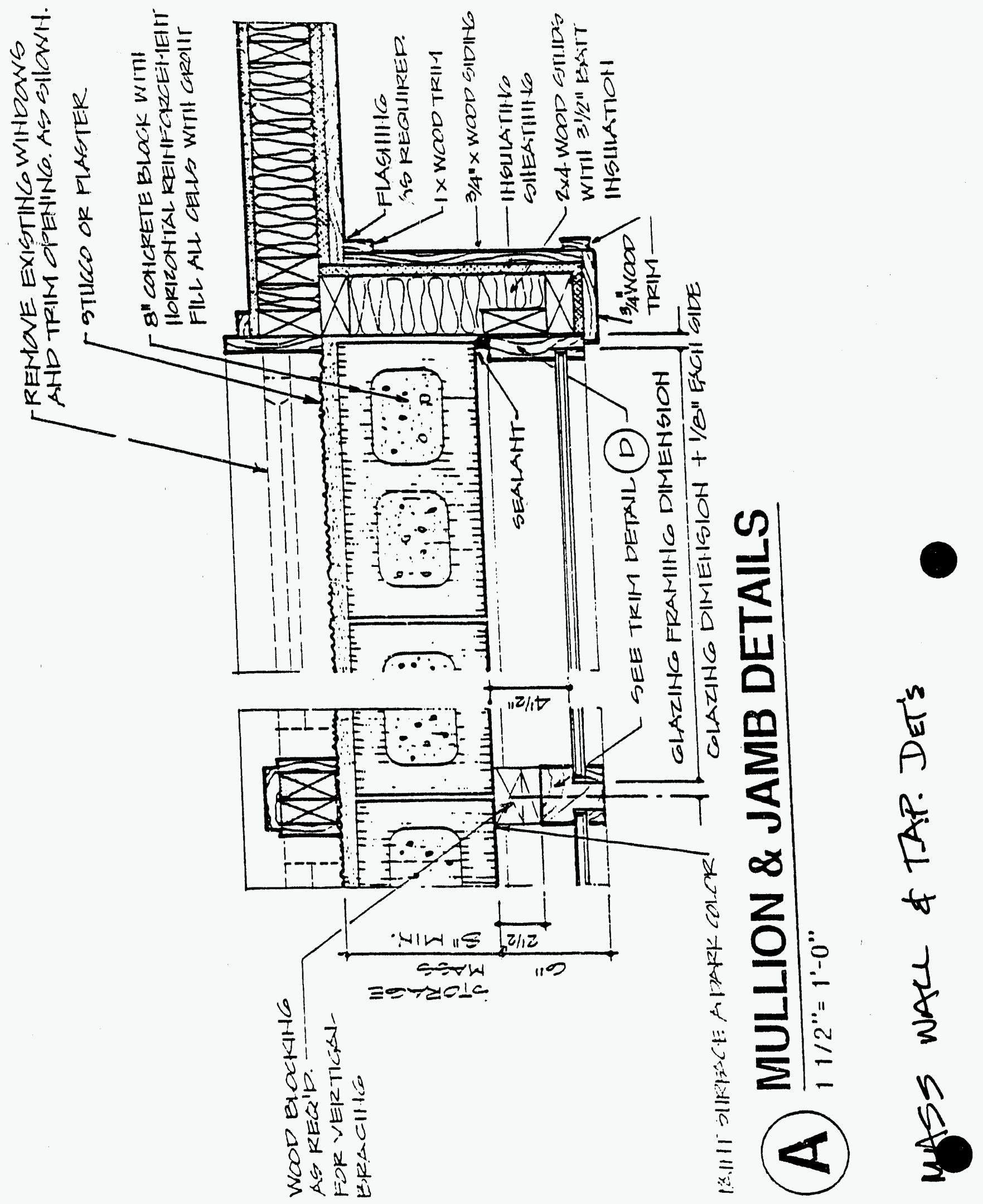




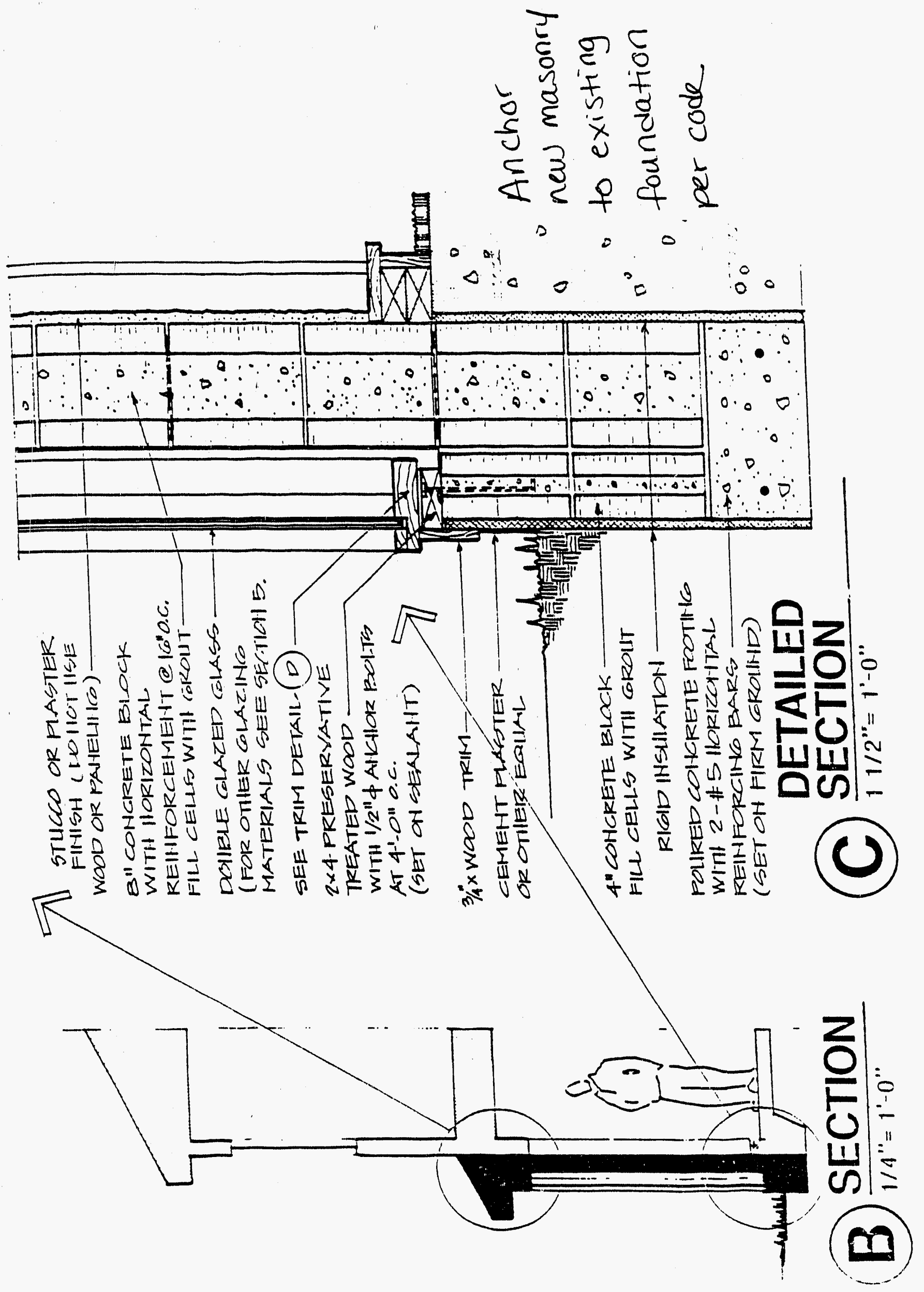




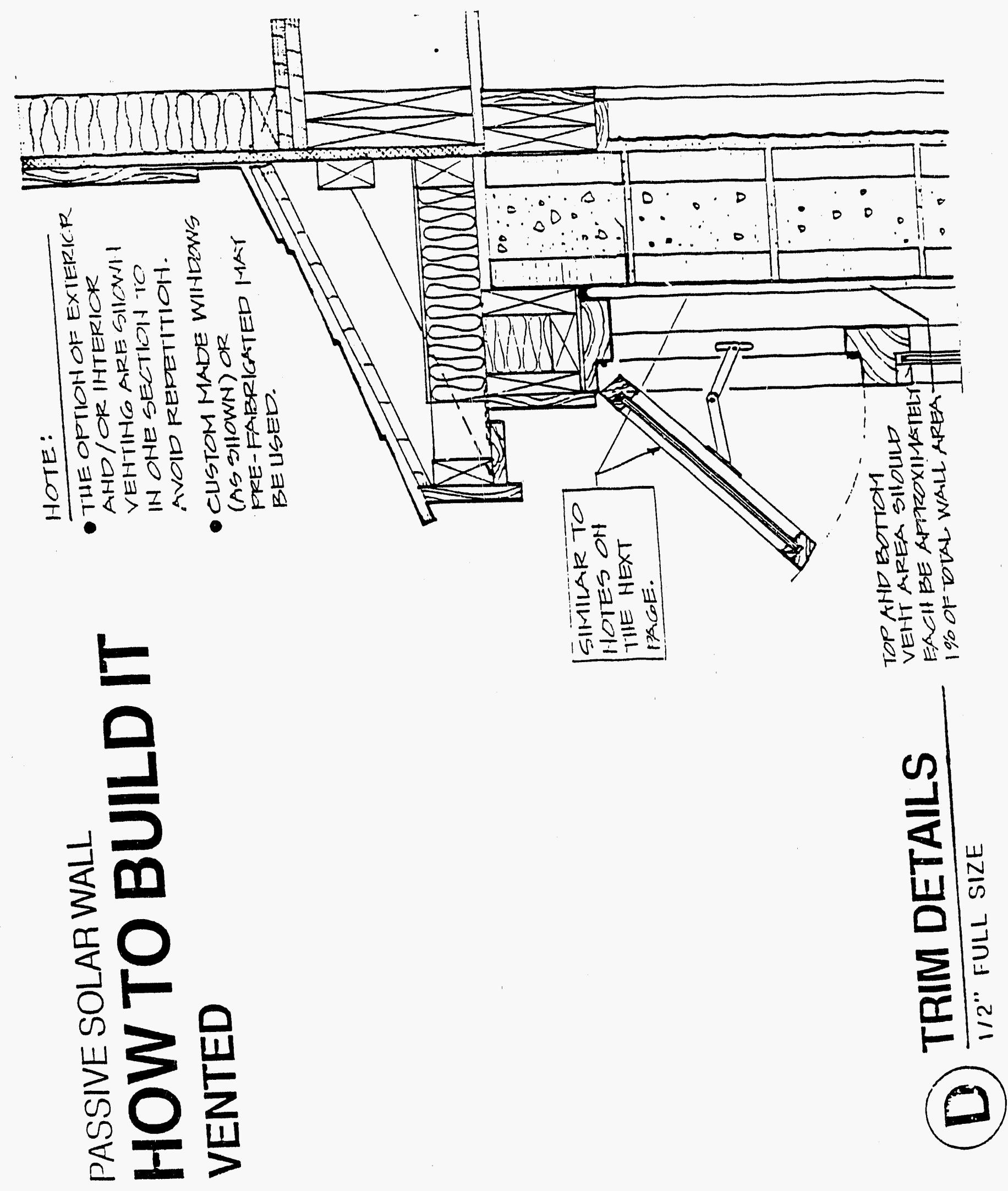




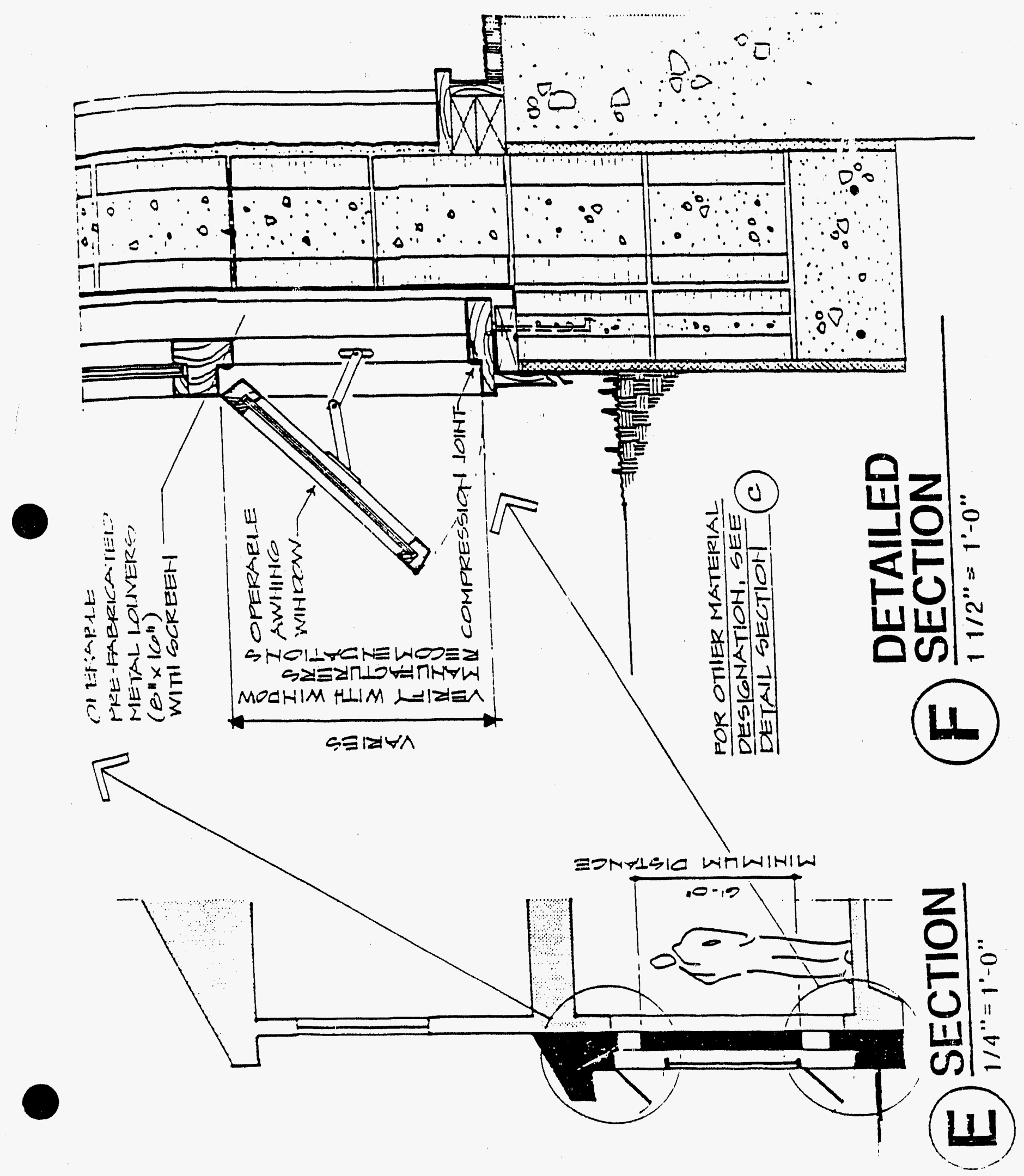



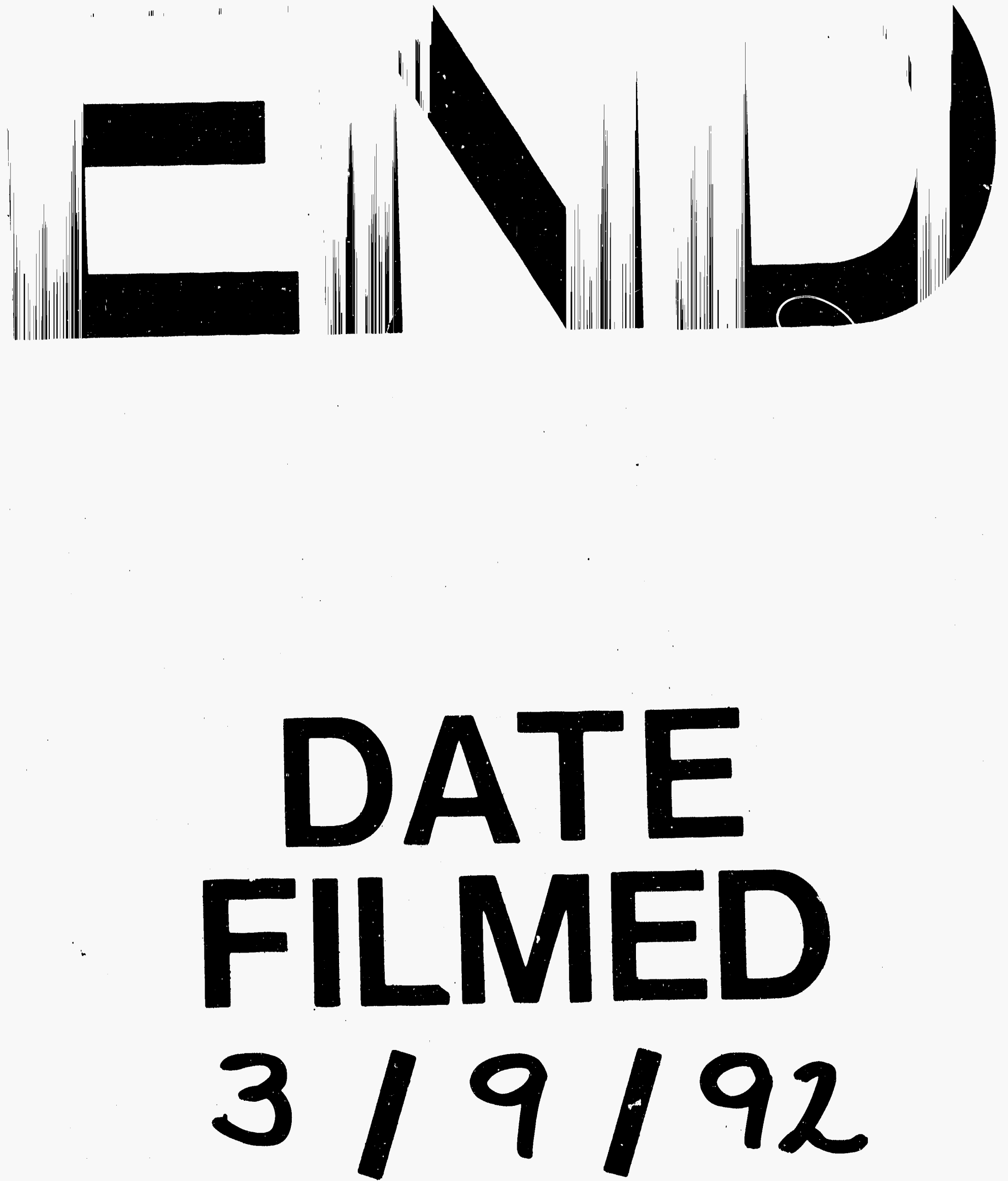

1 
